\title{
Locatable Mineral Reports for Colorado, South Dakota, and Wyoming provided to the USDA Forest Service in Fiscal Years 2006-2009
}

By Anna B. Wilson

Open-File Report 2010-1084

U.S. Department of the Interior

U.S. Geological Survey 


\section{U.S. Department of the Interior KEN SALAZAR, Secretary}

\section{U.S. Geological Survey Marcia K. McNutt, Director}

U.S. Geological Survey, Reston, Virginia: 2010

For product and ordering information:

World Wide Web: http://www.usgs.gov/pubprod

Telephone: 1-888-ASK-USGS

For more information on the USGS-the Federal source for science about the Earth, its natural and living resources, natural hazards, and the environment:

World Wide Web: http://www.usgs.gov

Telephone: 1-888-ASK-USGS

Any use of trade, product, or firm names is for descriptive purposes only and does not imply endorsement by the U.S. Government.

Although this report is in the public domain, permission must be secured from the individual copyright owners to reproduce any copyrighted material contained within this report.

This report has not been reviewed for stratigraphic nomenclature.

Suggested citation:

Wilson, Anna B., 2010, Locatable mineral reports for Colorado, South Dakota, and Wyoming provided to the USDA Forest Service in Fiscal Years 2006-2009: U.S. Geological Survey Open-File Report 2010-1084.

[http://pubs.usgs.gov/of/2010/1084/] 


\section{Contents}

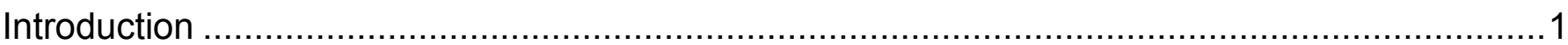

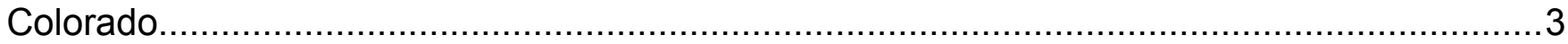

Arapaho/Roosevelt National Forests

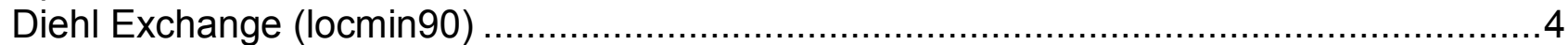

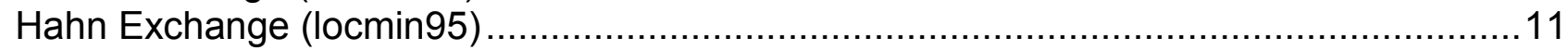

Gunnison National Forest

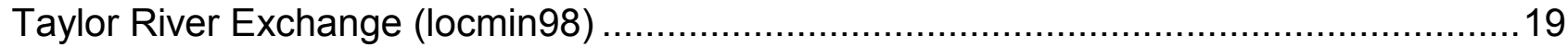

Gunnison-Uncompahgre-Grand Mesa (GMUG) National Forest

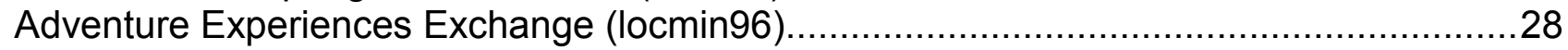

San Juan National Forest

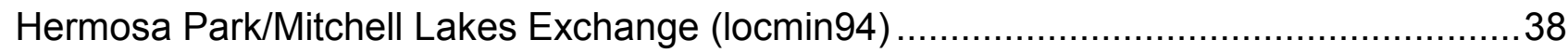

San Juan and Rio Grande National Forests

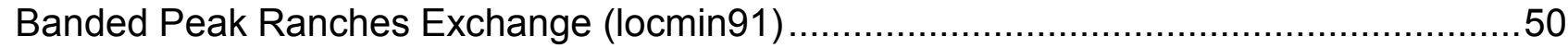

White River National Forest

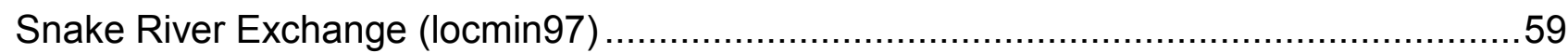

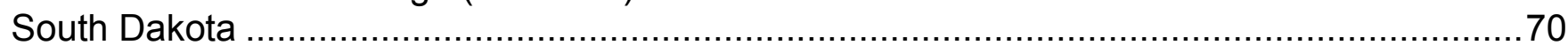

Black Hills National Forest

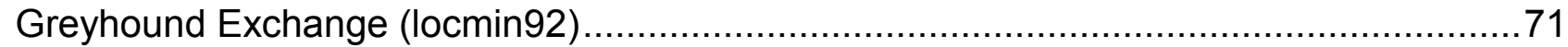

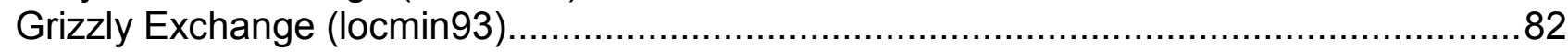

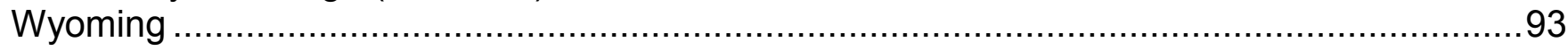

Black Hills National Forest

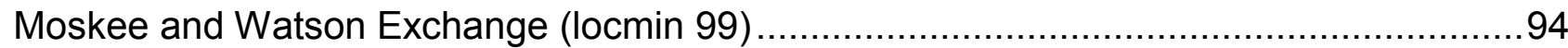




\section{Figures}

\section{Colorado}

Arapaho/Roosevelt National Forests

Diehl Exchange (locmin90)

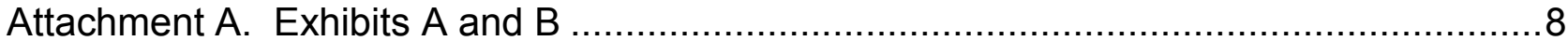

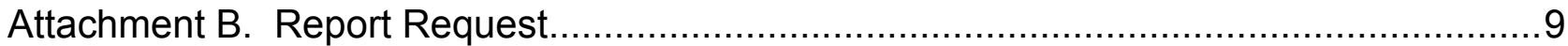

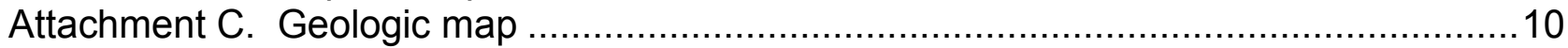

Hahn Exchange (locmin95)

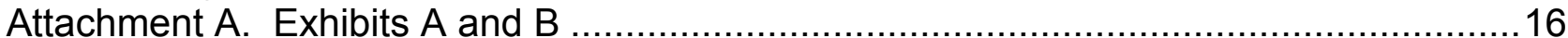

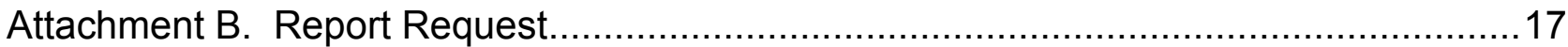

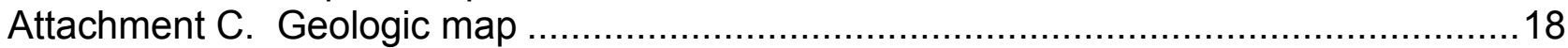

Gunnison National Forest

Taylor River Exchange (locmin98)

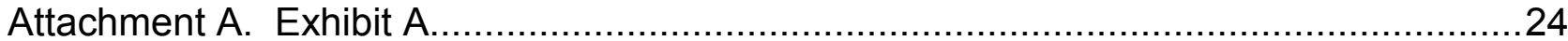

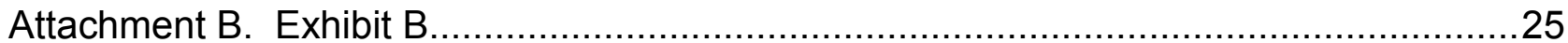

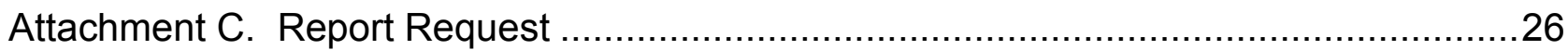

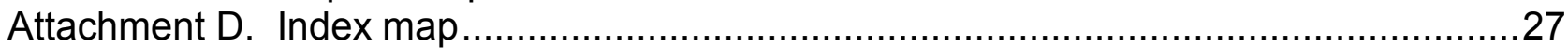

Gunnison-Uncompahgre-Grand Mesa (GMUG) National Forest

Adventure Experiences Exchange (locmin96)

Attachment A. Exhibit A.

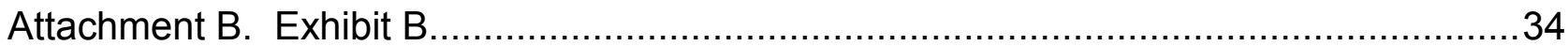

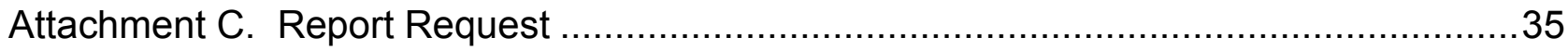

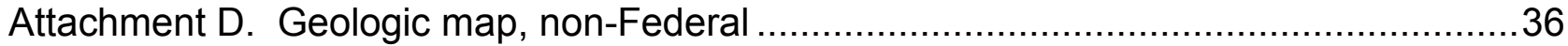

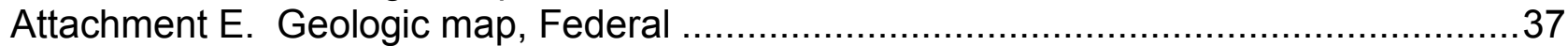

San Juan National Forest

Hermosa Park/Mitchell Lakes Exchange (locmin94)

Attachment A. Exhibit A

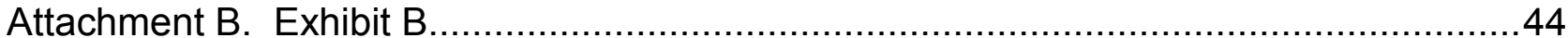

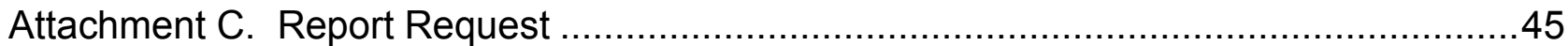

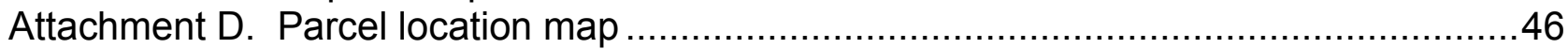

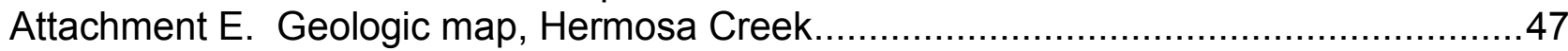

Attachment F. Geologic map, Mitchell Lakes .................................................... 48

Attachment G. Geologic map, Chris Park ............................................................... 49

San Juan and Rio Grande National Forests

Banded Peak Ranches Exchange (locmin91)

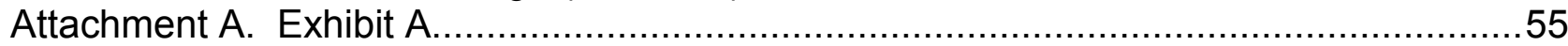

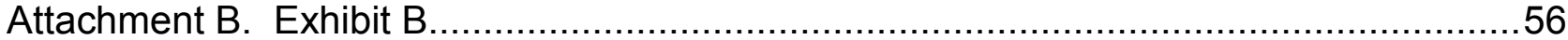

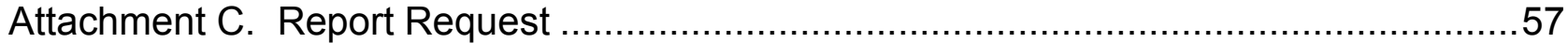

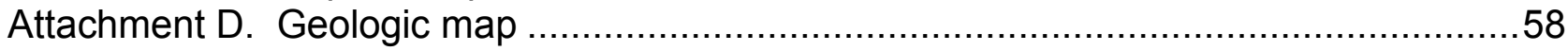


White River National Forest

Snake River Exchange (locmin97)

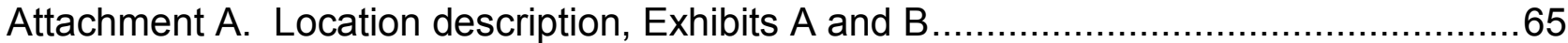

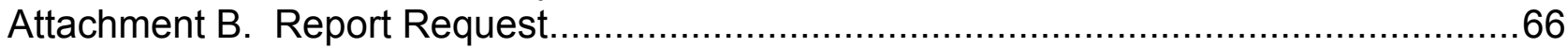

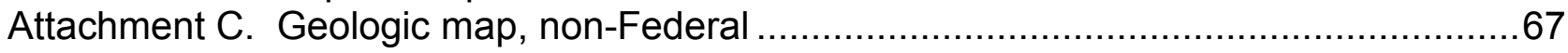

Attachment D. Geologic map, Dercum Dash......................................................68

Attachment E. Geologic map, Claimjumper and Cucumber Gulch..............................69

South Dakota

Black Hills National Forest

Greyhound Exchange (locmin92)

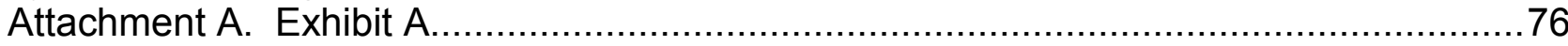

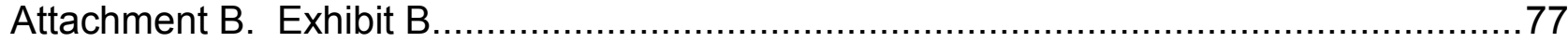

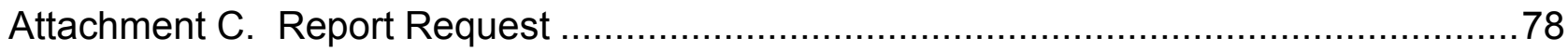

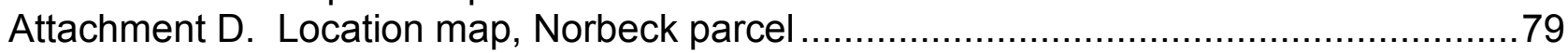

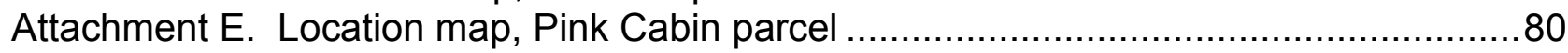

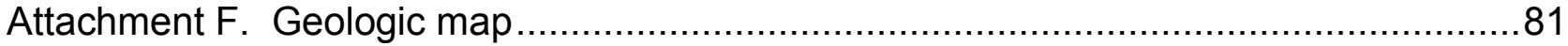

Grizzly Exchange (locmin93)

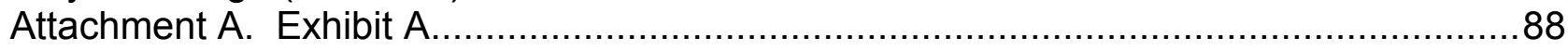

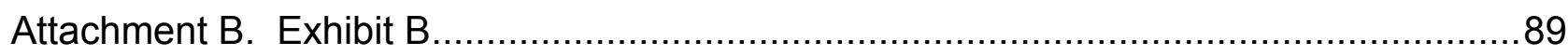

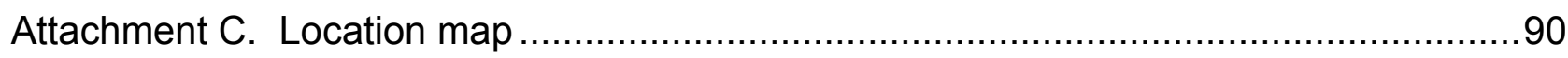

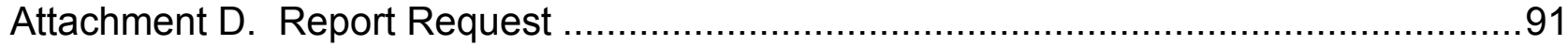

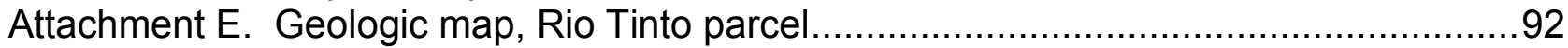

Wyoming

Bighorn/Black Hills National Forests

Moskee and Watson Exchange (locmin99)

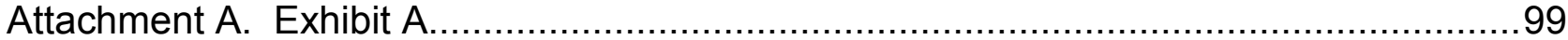

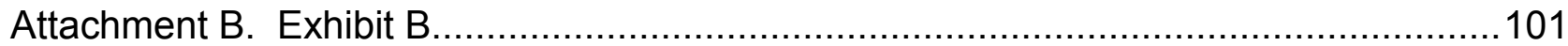

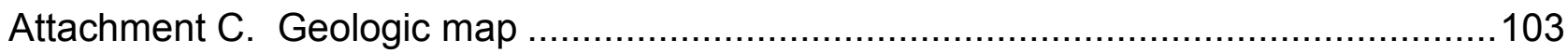

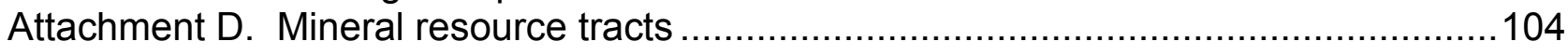

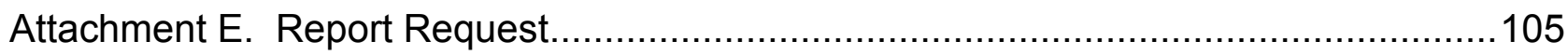

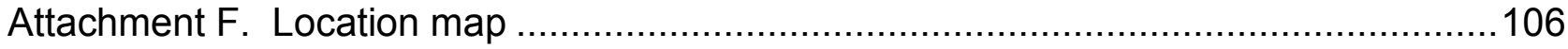




\section{Locatable Mineral Reports for Colorado, South Dakota, and Wyoming provided to the USDA Forest Service in Fiscal Years 2006-2009}

By Anna B. Wilson

\section{Introduction}

The U.S. Geological Survey is required by Congress (under Public Law 86-509) to provide Locatable Mineral Reports to the USDA Forest Service whenever National Forest System lands are sold or exchanged. This volume is a compilation of the reports already provided to the Forest Service by the author in fiscal years 2006-2009 (October 2006September 2009). Altogether, the reports describe the geology and locatable mineral resource potential of 57 properties offered in 10 land-exchange proposals. Approximately 41,084 acres were evaluated: 19,068 acres in Federal parcels and 22,016 acres in nonFederal parcels. The parcels are located in eight National Forests and one National Grassland in three States.

Locatable Mineral Reports provide a summary of the geology and a subjective appraisal of the mineral resource potential of land parcels considered for exchange. Information in each report is based on a review of published maps and reports, unpublished data in U.S. Geological Survey files, the professional expertise of the writer, and interviews with other knowledgeable geoscientists. No visits were conducted to support the reports included in this volume. The mineral resource information provided is used in making relative comparisons of the potential future mineral value of lands being offered in an exchange and in appraising the value of the land. Future mineral potential value is subjectively expressed in qualitative terms using a three-tier nomenclature of "high," "moderate," and "low." In general, "high" is applied where mineral deposits are present on the property or adjacent to it or there are other indications that the area has been mineralized. "Moderate" is applied where mineralization is only suspected or where an area possesses some of the same geologic characteristics that are common to areas around known mineral deposits. A "low" value is routinely applied to all remaining areas, with the understanding that the information required to prove the absence of any mineral resource potential will never be available. Copies of the reports reside in U.S. Geological Survey Mineral Resource Program and USDA Forest Service files.

Most recent land exchanges are proposed for mutual convenience to gather both Federal and private lands into manageable blocks. Land exchanges are being used to 
mitigate management and utilization problems associated with co-mingled Federal and private property ownership. Promotion of greater continuity of ownership and creation of more manageable and usable property units are influential factors in the property selection and consolidation process. Some proposals are by Towns, Counties, and States wishing to acquire lands to serve the common good of their constituencies. Others are motivated by ranchers wishing to consolidate or expand their grazing lands and increase the efficiency of their operations. Still others are proposed by owners of remote patented mining claims wishing to swap their tracts for more accessible parcels or to avoid liability for any potential hazards the site may develop as a result of prior mining. Many recent land-exchange offers are directed toward acquisition of public lands in high-value recreation areas such as ski areas. Increasingly, there is more potential for litigation and controversy for land exchanges involving high-value real estate than for exchanges of lower-profile grazing lands. Hence, locatable mineral reports must be reliable enough to withstand scrutiny from litigants vying for high-stakes real estate.

Ten reports are included in this volume. They are grouped by State, then alphabetically by Forest. Each starts with a cover letter and title page. Geologic descriptions of properties, their mineral potential, and references make up the main body of each report. Legal descriptions of the property locations (either verbatim or paraphrased from descriptions supplied by the Forest Service) are included as attachments designated Exhibits A and B. Also included as attachments are the report request from the USDA Forest Service and any index maps, geologic maps, or other figures or illustrations that are provided for the convenience of the Forest Service minerals examiner. Page numbers for each individual report are retained: the larger number at the bottom of each page is the pagination for this volume. 
COLORADO 


\title{
LOCATABLE MINERAL REPORT FOR THE DIEHL LAND EXCHANGE OFFER, PAWNEE NATIONAL GRASSLAND, ADMINISTERED BY ARAPAHO AND ROOSEVELT NATIONAL FORESTS, WELD COUNTY, COLORADO
}

\author{
By \\ Anna B. Wilson \\ U.S. Geological Survey \\ Administrative Report \\ December 12, 2005
}

The following report is based on information contained in USGS mineral resource and commodity files, mineral information databases (MRDS and MAS), and on reports and maps available in the USGS library. These data are occasionally augmented with unpublished documents, personal communications, and professional experiences. No field studies or on-site visits were performed in preparing this report. Emphasis is primarily on locatable mineral resources. Leasable and salable resources are covered only if they appear in the above documents. Mineral resource assessments are subjective: the opinions expressed herein are entirely those of the author. This report has not been reviewed for stratigraphic nomenclature. 
(303) 236-5593

awilson@usgs.gov

December 12, 2005

Mr. Randall Karstaedt

Director, Physical Resources

U.S. Forest Service

P.O. Box 25127

Lakewood, CO 80225-0127

Dear Mr. Karstaedt:

This report is in response to your September 2 request for information on locatable mineral resources in a land exchange proposal in which Elmer and Mildred Diehl have offered certain non-Federal lands within the Pawnee National Grassland, administered by the Arapaho and Roosevelt National Forests, in exchange for Federal lands also within the Pawnee National Grassland, administered by the Arapaho and Roosevelt National Forests.

In accordance with our long-term working agreement under Public Law 86-509, we are providing you with a report on the locatable mineral resources on the lands described in Exhibits $\mathrm{A}$ and $\mathrm{B}$, which were included with your request. These lands comprise approximately 640 acres in Weld County, Colorado.

Sincerely yours,

Anna B. Wilson, Geologist

Mineral Resources Program, Central Region

Copies: C.J. Nutt

N. Hollenkamp

J.S. Dersch 
For the legal location description of lands considered for exchange, refer to Exhibits A and B in Attachment A. The report request is Attachment B. Attachment $\mathrm{C}$ is a geologic map showing the approximate locations of the parcels.

\section{$\underline{\text { Non-Federal Lands } \square}$}

Diehl Property

Chalk Bluffs West, Chalk Bluffs East (formerly Eastman Creek North, Squaw Rock) 1:24,000, Eaton 1:100,000, Greeley 1:250,000 quadrangles.

The Diehl property is entirely within the Oligocene White River Group, a variegated fluvial tuffaceous siltstone and loosely to moderately well-cemented sandstone (Braddock and Cole, 1978; Mather and others, 1928). No detailed mapping of this region could be located.

No mines, prospects, or mineral occurrences of any locatable mineral commodities are in the vicinity. Mineral resource potential for all such commodities is low.

\section{Federal Lands $\square$}

$\mathrm{N} 1 / 2$, Sec. 12

Chalk Bluffs Southeast (formerly Eastman Creek SE) 1:24,000, Eaton 1:100,000, Greeley 1:250,000 quadrangles.

The Federal property is entirely within the Upper Cretaceous Laramie Formation, an olive-gray silty shale that contains lenticular beds of sandstone, clay, and seams of coal (Braddock and Cole, 1978; Mather and others, 1928). No detailed mapping of this region could be located.

Several miles south of the parcel there are uranium occurrences described as "sand outcrop with uranium showings (Nelson-Moore and others, 1978) in the Fox Hills Sandstone (Mather and others, 1928) the unit that underlies the Laramie Formation. No other mines, prospects, or mineral occurrences of any locatable mineral commodities are in the immediate vicinity. Mineral resource potential for all locatable commodities is low. 


\section{REFERENCES:}

Braddock, W.A., and Cole, J.C., 1978, Preliminary geologic map of the Greeley $1^{\circ} \mathrm{X} 2^{\circ}$ quadrangle [Colorado]: U.S. Geological Survey Open-File Report 78-532, scale $1: 250,000$.

Mather, K.F., Gilluly, J., and Lusk, R.G., 1928, Geology and oil and gas prospects of northeastern Colorado: U.S. Geological Survey Bulletin 796, p. 65-124, scale $1: 250,000$.

Nelson-Moore, J.L., Collins, D.B., and Hornbaker, A.L., 1978, Radioactive mineral occurrences of Colorado: Colorado Geological Survey Bulletin, 40, 1054 p.

Wilson, A.B., 2003, Databases and simplified geology for mineralized areas, claims, mines and prospects in Colorado: U.S. Geological Survey Open-File Report 03-090.

\section{LIST OF ATTACHMENTS:}

A. Exhibits A and B. Legal description of land considered in this exchange, exclusive of Outstanding Rights (provided by USDA Forest Service).

B. Report request (provided by USDA Forest Service).

C. Geologic map showing approximate location of the Diehl exchange properties (after Braddock and Cole, 1978; Wilson, 2003, and unpublished data). 
Attachment A. Exhibits A and B: Legal description of land considered in this exchange. exclusive of Outstanding Rights (provided by U.S.D.A. Forest Service).

\section{EXHIBIT A}

Property that the Non-Federal Party will consider exchanging:

\section{Sixth Principal Meridian, Weld County, Colorado}

T. 11 N., R. $65 \mathrm{~W}$. Sec. $26, N^{1} / 2$.

Containing 320 acres, more or less.

Land reservations of the Non-Federal Party and exceptions to title:

Reservations: None

Outstanding Rights:

\section{EXHIBIT B}

Property that the U.S.D.A. Forest Service will consider exchanging:

\section{Sixth Principal Meridian, Weld County, Colorado}

\section{T. 10 N., R. $65 \mathrm{~W}$. sec. $12, \mathrm{~N}^{1} / 2$}

Containing 320 acres, more or less.

Land reservations of the U.S.D.A. Forest Service, exceptions to title and uses to be recognized:

Reservations: None

Outstanding Rights: 
Attachment B. Report Request (provided by U.S.D.A. Forest Service).

$\begin{array}{lll}\begin{array}{l}\text { United States } \\ \text { Department of }\end{array} & \text { Forest } & \text { Rocky } \\ \text { Agriculture } & \text { Service } & \begin{array}{l}\text { Mountain } \\ \text { Region }\end{array}\end{array}$

P.O. Box 25127

Lakewood, CO 80225-0127

Delivery: 740 Simms Street

Golden, CO 80401

Voice: 303-275-5350

TDD: 303-275-5367

\footnotetext{
File Code: $5430-2-1$

Date: SEP - 22005

Anna Wilson

Geologist

Central Mineral Resources

U.S. Geological Survey MS 905

Box 25046, Denver Federal Center

Denver, CO 80225

Dear Ms. Wilson:

Elmer A. and Mildred C. Diehl, of 27789 Weld County Road 108, Ault, Colorado, have offered certain non-Federal lands within the Pawnee National Grassland, administered by the Arapaho and Roosevelt National Forests, in exchange for Federal lands also within the Pawnee National Grassland, administered by the Arapaho and Roosevelt National Forests. These lands are generally described in Exhibits A and B enclosed herewith. The lands to be exchanged are depicted on the maps also provided.

In accordance with the working agreement under Public Law 86-509, please provide a report on the locatable mineral resources on the lands described in Exhibits A and B. Please specify in your report the mineral or minerals involved. Please send your report to the letterhead address.

If you have any questions, you may contact Nancy Hollenkamp at (303) 275-5382.

Sincerely,

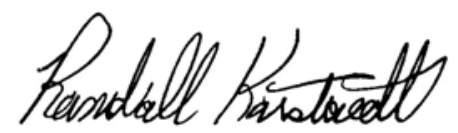

RANDALL KARSTAEDT

Director, Physical Resources

Enclosures

cc: Susan Leschnik, Lisa M Subcasky, John Oppenlander
} 
Attachment C. Geologic map showing approximate location of exchange parcels (red, private; green, federal) (after Braddock and Cole, 1978; Wilson, 2003 and unpublished data, 2005). Rock units of interest include: Twr, Oligocene White River Formation and Kl, Upper Cretaceous Laramie Formation. Mines, prospects, or occurrences are from the USGS MAS and MRDS databases (Wilson, 2003): uranium is shown as yellow squares, gravel pits as blue X's, industrial mineral occurrences as black circles. Locations have not been verified and may be unreliable.

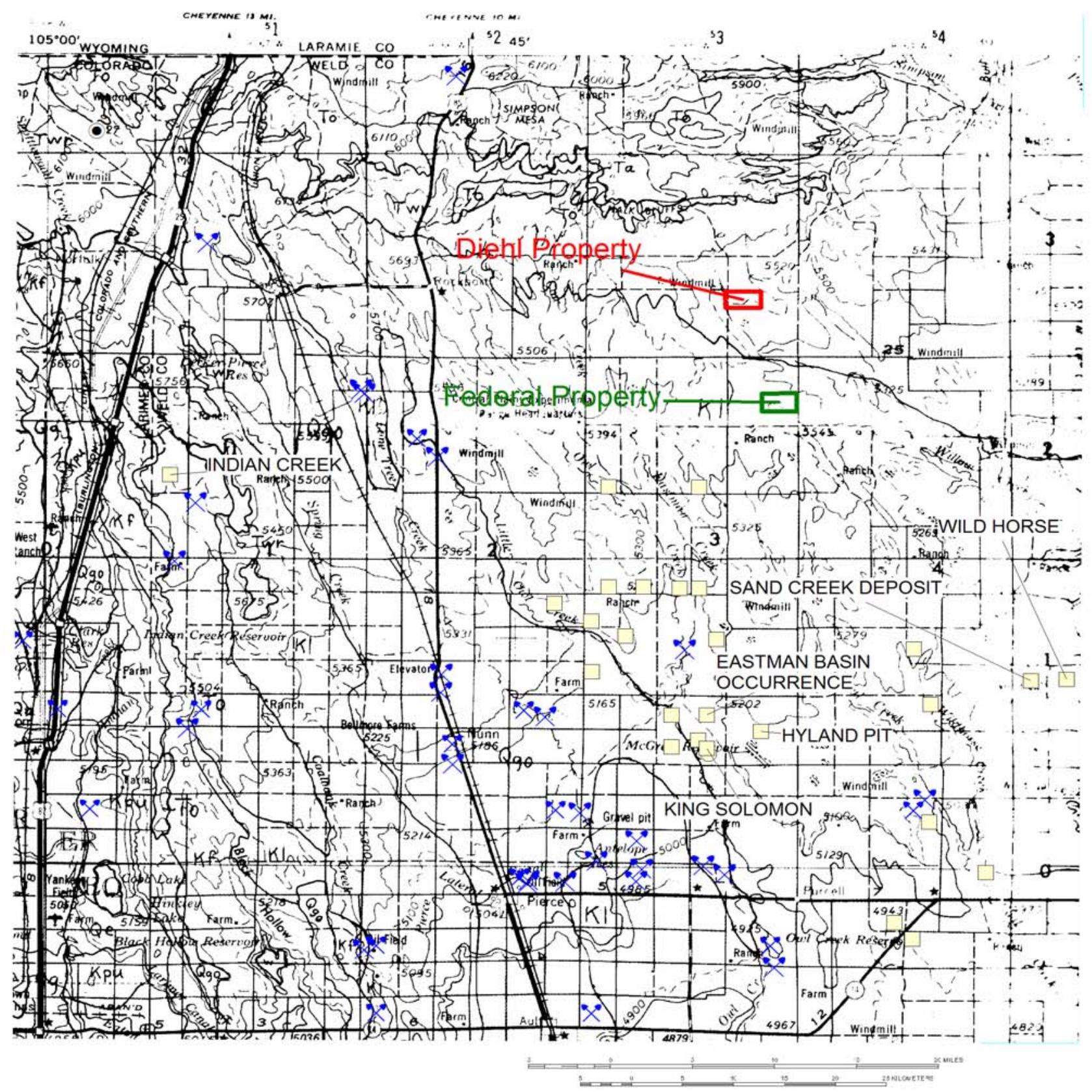




\title{
LOCATABLE MINERAL REPORT FOR THE HAHN LAND EXCHANGE OFFER, PAWNEE NATIONAL GRASSLAND, ARAPAHO AND ROOSEVELT NATIONAL FORESTS, WELD COUNTY, COLORADO
}

\author{
By \\ Anna B. Wilson \\ U.S. Geological Survey \\ Administrative Report \\ December 14, 2007
}

The following report is based on information contained in USGS mineral resource and commodity files, mineral information databases (MRDS and MAS), and on reports and maps available in the USGS library. These data are occasionally augmented with unpublished documents, personal communications, and professional experiences. No field studies or onsite visits were performed in preparing this report. Emphasis is primarily on locatable mineral resources. Leasable and salable resources are covered only if they appear in the above documents. Mineral resource assessments are subjective: the opinions expressed herein are entirely those of the author. This report has not been reviewed for stratigraphic nomenclature. 
U.S. Department of the Interior

U.S. Geological Survey

Box 25046, MS 973

Denver Federal Center

Denver CO, 80225

December 10, 2007

Mr. Randall Karstaedt

Director, Physical Resources

U.S. Forest Service

P.O. Box 25127

Lakewood, CO 80225-0127

Dear Mr. Karstaedt:

This report is in response to your December 3, 2007 request (received 12/5) for information on locatable mineral resources in a land exchange proposal in which Eugene and Sharon Hahn have offered certain non-Federal lands within the Pawnee National Grassland (administered by the Arapaho and Roosevelt National Forests) in exchange for Federal lands also within the Pawnee National Grassland.

In accordance with our long-term working agreement under Public Law 86-509, we are providing you with a report on the locatable mineral resources on the lands described in Exhibits $\mathrm{A}$ and $\mathrm{B}$, which were included with your request. These lands comprise approximately 640 acres in Weld County, Colorado.

Sincerely yours,

Anna B. Wilson, Geologist

Mineral Resources Program, Central Region

(303) 236-5593

awilson@usgs.gov

Copies: $\quad$ C.J. Nutt

N. Hollenkamp

M. Dunn

E. Moncrief

J. Oppenlander 
For the legal location description of lands considered for exchange exclusive of Reservations, Outstanding Rights, or other restrictions, refer to Exhibits A and B in Attachment A. The report request is Attachment $\mathrm{B}$. Attachment $\mathrm{C}$ is a simplified geologic map showing both parcel locations.

\section{Non-Federal Lands}

Bringleson Allotment (Hahn Property)

Raymer NW 1:24,000, Sterling 1:100,000, Sterling 1:250,000 quadrangles.

The Bringleson Allotment (Hahn property) is in an area mapped at 1:250,000 scale (or smaller) as White River Group (Attachment C), primarily ashy claystone and sandstone (Scott, 1978; Tweto, 1979; Green, 1992). In Weld County the White River Group lithologies include silt, fine sands, and gravel deposits [http://www.oil-gas.state.co.us/orders/orders/1R/12.html]. White River Group may include as many as 13 layers of volcanic tuff [http://www.douglasfossils.com/paleo_geo3.html], but detailed mapping is not available to determine if these are present in the parcel. White River Group is divided into the Chadron Formation in the lower part and the Brule Formation in the upper part. Because the geologic maps cited above were published, the age of the Chadron Formation has been revised from Oligocene to late Eocene, based on ${ }^{40} \mathrm{Ar} /{ }^{39} \mathrm{Ar}$ dates on biotite (Prothero and Swisher, 1992; [http://ngmdb.usgs.gov/Geolex/NewRefsmry/sumry_7037.html] and [http://ngmdb.usgs.gov/Geolex/NewRefsmry/sumry_7360.html]), therefore making the White River Group late Eocene to Oligocene in age. Near the middle of the parcel, the sedimentary rocks are overlain by Pleistocene Slocum Alluvium, a terrace gravel perched about $60 \mathrm{ft}(18 \mathrm{~m})$ above the South Platte River. The alluvium is composed of "clayey limonitic or calcareous sand and gravel” (Scott, 1978).

Although there are no known mines within 2 1/2 miles of the parcel, the White River Group is widely known for its fossil-collecting localities, especially Titanotherium teeth, reptiles, and modern and extinct mammals [http://www.douglasfossils.com/paleo_geo3.html]. White River Group also contains chalcedony, which was used by early native peoples to make tools such as flake cores and scrapers (Basham and Holen, 2006). Other materials that have been explored and(or) exploited from the White River Group nearby include manganese, silica, pumice, and uranium (Wilson, 2003; A.B. Wilson, U.S. Geological Survey, unpublished data, 2007). White River Group is thought to be the source for uranium in roll-front deposits east of the Front Range (B.S. Van Gosen, oral communication, December 6, 2007). The parcel is within 5 miles of several oil fields and gas fields (Scott, 1978).

The only locatable mineral with high mineral resource potential within this parcel is uranium. There is low potential for other locatable mineral commodities. However, potential for energy commodities such as uranium and oil and gas is high. If the quality of the alluvium is adequate, the resource potential for sand and gravel, a salable commodity, in the Slocum Alluvium could be high. 


\section{Federal Lands}

\section{Tower Allotment}

Grover NE 1:24,000, Eaton 1:100,000, Greeley 1:250,000 quadrangles.

Geology underlying the Tower Allotment (Attachment C) is the basal part of the Miocene and Pliocene(?) Ogallala Formation, composed of sandstone and conglomerate (Braddock and Cole, 1978; Tweto, 1979; Green, 1992). Because the parcel is near the mapped contact with the underlying White River Formation, it is assumed that the parcel is in the basal part of the Ogallala Formation and therefore is Miocene rather than Pliocene in age.

No mines are known in the vicinity of the parcel (Wilson, 2003; A.B. Wilson, U.S. Geological Survey, unpublished data, 2007), nor is the Ogallala Formation locally known to host mineral deposits. Mineral resource potential for locatable minerals is low.

\section{LIST OF ATTACHMENTS:}

A. Exhibits A and B. Legal description of lands considered in this exchange (provided by the USDA Forest Service) exclusive of Reservations and Outstanding rights.

B. Report request (provided by the USDA Forest Service).

C. Simplified geologic map showing the location of the parcels (after Tweto, 1979; Green, 1992; Wilson, 2003). 


\section{REFERENCES:}

Basham, Matt, and Holen, Steven, 2006, Easterday II Cache-A flake core cache from Weld County, CO: Southwestern Lore, Journal of Colorado Archeology, v. 72, no. 2, p. 1-14.

Braddock, W.A., and Cole, J.C., 1978, Preliminary geologic map of the Greeley $1^{\circ} \times 2^{\circ}$ quadrangle, Colorado and Wyoming: U.S. Geological Survey Open-File Report 78-532, scale 1:250,000.

Green, G.N., 1992, The digital geologic map of Colorado in ARC/INFO format: U.S. Geological Survey Open-File Report 92-507-D-O, available online at [http://pubs.usgs.gov/of/1992/ofr-92-0507/].

Prothero, D.R. and Swisher, C.C., 1992, Magnetostratigraphy and geochronology of the terrestrial Eocene-Oligocene transition in North America in Eocene-Oligocene climatic and biotic evolution: Princeton University Press, p. 46-73.

Tweto, Ogden, 1979, Geologic map of Colorado: U.S. Geological Survey, scale 1:500,000.

Scott, G.R., 1978, Map showing geology, structure, and oil and gas fields in the Sterling $1^{\circ} \mathrm{x} 2^{\circ}$ quadrangle, Colorado, Nebraska, and Kansas: U.S. Geological Survey Miscellaneous Investigations Series Map I-1092, scale 1:250,000, 2 sheets.

Wilson, A.B., 2003, Databases and simplified geology for mineralized areas, claims, mines and prospects in Colorado: U.S. Geological Survey Open-File Report 2003-90, available online at [http://pubs.usgs.gov/of/2003/ofr-03-090/]. 
Attachment A. Exhibits A and B-Legal description of lands considered in this exchange (provided by the USDA Forest Service) exclusive of Reservations and Outstanding rights.

$\underline{\text { EXHIBIT A }}$

Property that the non-Federal Party will consider exchanging:

Sixth Principal Meridian, Weld County, Colorado

T. 9 N., R. $58 \mathrm{~W}$.

Sec. $32, N^{1} / 2$.

Containing 320 acres, more or less.

\section{EXHIBIT B}

Property that the United States will consider exchanging:

Sixth Principal Meridian, Weld County, Colorado

T. 11 N., R. $60 \mathrm{~W}$. sec. $34, \mathrm{~N}^{1} / 2$

Containing 320 acres, more or less. 


\section{Attachment B. Report Request (provided by the USDA Forest Service).}

\begin{tabular}{|llll} 
USDA United States & Forest & Rocky & 740 Simms Street \\
Department of & Service & Mountain & Golden, CO 80401 \\
Agriculture & & Region & Voice: 303-275-5350 \\
& & TDD: $303-275-5367$ \\
\hline
\end{tabular}

Anna Wilson

File Code: $5430-2-1$

Date:

Geologist

U.S. Geological Survey MS 905

Central Mineral Resources

Box 25046, Denver Federal Center

Denver, CO 80225

Dear Ms. Wilson:

Eugene D. and Sharon H. Hahn, husband and wife, of 52701 Weld County Road 124, Grover, Colorado, have offered certain non-Federal lands within the Pawnee National Grassland, administered by the Arapaho and Roosevelt National Forests, in exchange for Federal lands also within the Pawnee National Grassland. These lands are generally described in Exhibits A and B enclosed herewith. The lands to be exchanged are depicted on the maps also provided.

In accordance with the working agreement under Public Law 86-509, please provide a report on the locatable mineral resources on the lands described in Exhibits A and B. Please specify in your report the mineral or minerals involved. Please send your report to the letterhead address.

If you have any questions, you may contact Nancy Hollenkamp at (303) 275-5382.

Sincerely,

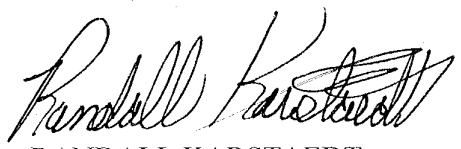

RANDALL KARSTAEDT

Director, Physical Resources

Enclosures

cc: Elizabeth S Moncrief, John Oppenlander 


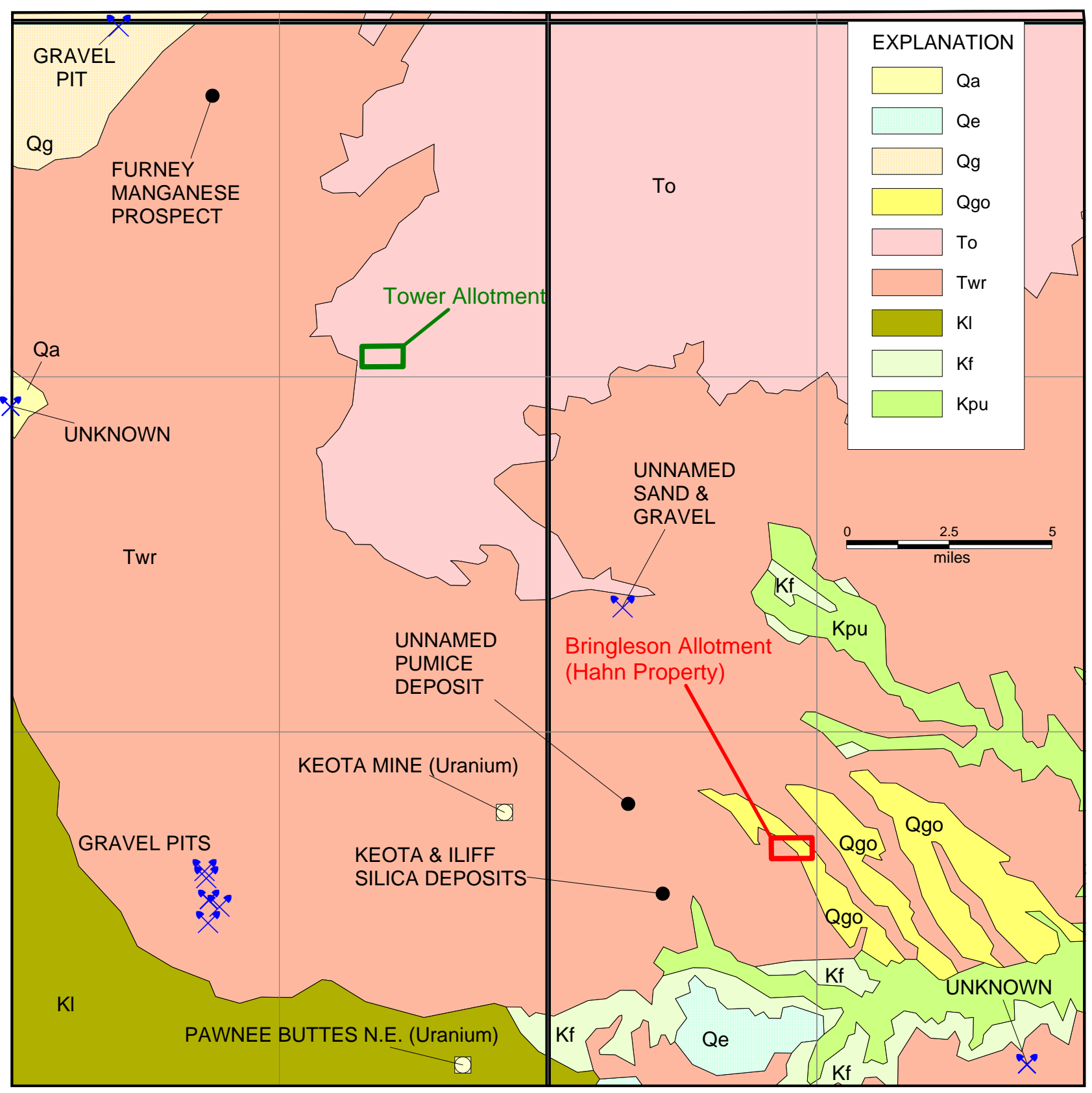

Attachment C. Simplified geologic map showing the location of the parcels (after Tweto, 1979; Green, 1992; Wilson, 2003). Qa, Quaternary alluvium; Qe, Quaternary eolian deposits; Qg, Quaternary gravels and alluvium; Qgo, Quaternary older gravels and alluvium (equivalent of Slocum Alluvium); To, Miocene and Pliocene(?) Ogallala Formation; Twr, late Eocene to Oligocene White River Group; KI, Cretaceous Laramie Formation; Kf, Cretaceous Fox Hills Sandstone; and Kpu, Cretaceous upper member of Pierre Shale. Names and locations of the mines and prospects (after Wilson, 2003) have not been verified. Approximate scale 1:250,000. 
LOCATABLE MINERAL REPORT FOR THE

TAYLOR RIVER LAND EXCHANGE OFFER, GUNNISON NATIONAL FOREST, GUNNISON COUNTY, COLORADO

By

Anna B. Wilson

U.S. Geological Survey

Administrative Report

May 23, 2008

The following report is based on information contained in USGS mineral resource and commodity files, mineral information databases (MRDS and MAS), and on reports and maps available in the USGS library. These data are occasionally augmented with unpublished documents, personal communications, and professional experiences. No field studies or onsite visits were performed in preparing this report. Emphasis is primarily on locatable mineral resources. Leasable and salable resources are covered only if they appear in the above documents. Mineral resource assessments are subjective: the opinions expressed herein are entirely those of the author. This report has not been reviewed for stratigraphic nomenclature. 


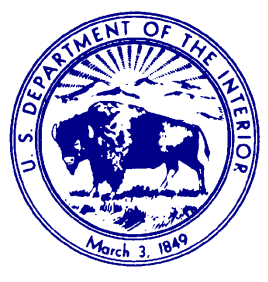

U.S. Department of the Interior

U.S. Geological Survey

Box 25046, MS 973

Denver Federal Center

Denver CO, 80225

May 23, 2008

Mr. Randall Karstaedt

Director, Physical Resources

U.S. Forest Service

P.O. Box 25127

Lakewood, CO 80225-0127

Dear Mr. Karstaedt:

This report is in response to your March 19, 2008 request (received 3/24/08) for information on locatable mineral resources in a land exchange proposal in which The Trust under the Will of Ernest Cockrell, Jr. has offered certain non-Federal lands within the Gunnison National Forest in exchange for Federal lands also within the Gunnison National Forest.

In accordance with our long-term working agreement under Public Law 86-509, we are providing you with a report on the locatable mineral resources on the lands described in Exhibits $\mathrm{A}$ and $\mathrm{B}$, which were included with your request. These lands comprise approximately 14 acres in Gunnison County, Colorado.

Sincerely yours,

Anna B. Wilson, Geologist

Mineral Resources Program, Central Region

(303) 236-5593

awilson@usgs.gov

Copies: C.J. Nutt

N. Hollenkamp

M. Dunn 
For the legal location description of lands considered for exchange (exclusive of Reservations, Outstanding Rights, or other restrictions), refer to Exhibits A and B in Attachments A and B. The report request is Attachment $\mathrm{C}$. An index map showing the approximate location of the study area is Attachment D.

\section{Federal and Non-Federal Lands}

Matchless Mountain 1:24,000, Taylor Park Reservoir 1:24,000, Gunnison 1:100,000, and Montrose 1:250,000 quadrangles.

Published detailed geologic mapping of this area along the Taylor River from Taylor Park Reservoir to Lottis Creek is lacking. Mapping of the Montrose $2^{\circ}$ sheet at 1:250,000 scale (Tweto and others, 1976) covers the entire area, a map by DeWitt and others (2002) at 1:30,000 scale covers only the southern third of the area. O'Connor (1961) mapped the area west of Taylor River. Rectifying the maps is problematic and currently is being undertaken by Ed DeWitt (Ed DeWitt, U.S. Geological Survey, written commun., 2008).

The study area along Taylor River can roughly be divided in thirds. The northern third of the area along Taylor River south of the dam is in porphyritic, coarse-grained, 1.7-Ga Henry Mountain Granite. The middle third is equigranular, medium-grained 1.4-Ga Taylor Park Granite which intruded the older granite. In the southern third, Paleozoic Sawatch overlies the younger granite south of an apparent fault. The southernmost part of the area (south of $38^{\circ} 47^{\prime}$ 30") is mapped as Holocene and Pleistocene alluvial and glacial deposits.

Ed DeWitt (written commun., 2008) points out that the Paleozoic rocks in the region may be intruded by Cretaceous-Tertiary sills, laccoliths, and stocks, mostly west of Matchless Mountain which lies to the west. South of the study area, in the Fossil Ridge area, the more mafic and alkalic of these intrusions are the $70 \mathrm{Ma}$ (latest Cretaceous) Fossil Ridge Latite. Some of the rhyolitic rocks west of Taylor River may be Miocene age (approx. 24 to $5 \mathrm{Ma}$ ), but none are mapped in the study area. Thrust faults with east-vergence have deformed all of the rock sequences in the vicinity. DeWitt suggests the faults are 65-60 Ma in age.

The nearest mineralized area is Spring Creek, located more than $4.5 \mathrm{mi}$ to the west. Deposits in this vicinity are small skarn and replacement lead-zinc-copper-silver-gold deposits in Paleozoic rocks related to Cretaceous and Tertiary intrusions (Ed DeWitt, written commun., 2008). There is no evidence in the literature that there are any lode mines nearer to the study area: no mineral deposits are known to occur in the Taylor River from the Taylor River Canyon at the outlet from Taylor Park Reservoir to the Junction with Lottis Creek at Lottis Creek Campground (Wilson, 2003; A. Wilson, USGS, 2008, unpublished data; U.S. Geological Survey, 2008). Regionally, the known deposits in Paleozoic rocks are Sherman-type silver and lead replacements in the carbonates. Carbonate rocks are not mapped in the study area, but may be present father west.

In his extensive compilation of gold placers in Colorado, Parker (1974, p. 99-110) states "the principal placers were in Taylor Park along Taylor River (beneath the present reservoir)", but he 
does not indicate the presence of any such placers on his maps (pl. 29, p. 102-103). There were gold placers in the upper reaches of Lottis Creek (in Union Canyon near the junction with Union Creek, and in East Union Creek). Runoff from any deposits in the upper reaches of Lottis Creek and Union Park would drain into Taylor River immediately above the southernmost tract "South Exchange Area," but below all the other parcels considered in this exchange.

In the study area, mineral resource potential for all locatable commodities in lodes is low. Resource potential for gold in placers is moderate for the part of the area north of Lottis Creek, purely by virtue of the lands being patented claims. At the time of patent, the claims were determined to contain an economically viable placer gold deposit, although there is currently no evidence for anything more than low resource potential in this part of the Creek. South of Lottis Creek resource potential for placer gold is high. Placer deposits do occur in the upper reaches of Lottis Creek and it is possible that some of the gold could have been transported downstream to this southernmost tract. No significant resources were noted in this area during a mineral resource study of the surrounding National Forests (Bankey, 2004)

\section{LIST OF ATTACHMENTS:}

A. Exhibit A. Legal description of non-Federal land considered in this exchange (provided by the USDA Forest Service) exclusive of reservations and outstanding rights.

B. Exhibit B. Legal description of Federal land considered in this exchange (provided by the USDA Forest Service) exclusive of reservations and outstanding rights.

C. Report request (provided by the USDA Forest Service).

D. Index map showing approximate location of the study area. 


\section{REFERENCES:}

Bankey, Viki, ed., 2004, Resource potential and geology of the Grand Mesa, Uncompahgre, and Gunnison (GMUG) National Forests and vicinity, Colorado: U.S. Geological Survey Bulletin 2213, 276 p.

DeWitt, Ed, Zech, R.S., Chase, C.G., Zartmann, R.E., Kucks, R.P., Bartelson, Bruce, Rosenlund, G.C., and Early, Drummond, III, 2002, Geologic and aeromagnetic maps of the Fossil Ridge area and vicinity, Gunnison County, Colorado: U.S. Geological Survey Geologic Investigations Series I-2738, scale 1:30,000, 42 p. pamphlet.

O’Connor, T.E., 1961, The structure and stratigraphy of an area west of Taylor Park, northeast Gunnison County, Colorado: Boulder, University of Colorado M.S. thesis, 97 p.

Parker, B.H., Jr., 1974, Gold placers of Colorado: Colorado School of Mines Quarterly, v. 69, no. 4, book 2, p. 99-118.

Tweto, Ogden, Steven, T.A., Hail, W.J., Jr., and Moench, R.H., 1976, Preliminary geologic map of the Montrose 1 X 2 quadrangle, southwestern Colorado: U.S. Geological Survey Miscellaneous Field Studies Map MF-761, scale 1:250,000.

U.S. Geological Survey, 2008, Mineral Resources Data System (MRDS), http://tin.er.usgs.gov/mrds/.

Wilson, A.B., 2003, Databases and simplified geology for mineralized areas, claims, mines and prospects in Colorado: U.S. Geological Survey Open-File Report 2003-90, http://pubs.usgs.gov/of/2003/ofr-03-090/. 


\section{Attachment A. Exhibit A-Legal description of non-Federal lands considered in this exchange exclusive of reservations, outstanding rights, or other interests (provided by the USDA Forest Service).}

EXHIBIT A

Property that the Non-Federal Party will consider exchanging*

At the northern extremity of the Taylor River Placer, generally located in: T.14S., R.83W., Sixth Principal Meridian, Gunnison County, Colorado Section 24: SW1/4 SE1/4 SW1/4

\begin{tabular}{|c|c|c|}
\hline PARCEL \# & SQUARE FEET & ACREAGE \\
\hline Stream for Stream & 31,307 & 0.719 \\
\hline
\end{tabular}

Near the midpoint of the Taylor River Placer, generally located in : T.14S., R.83W., Sixth Principal Meridian, Gunnison County, Colorado Section 26, SW1/4 NE1/4 SE1/4

\begin{tabular}{|c|c|c|}
\hline PARCEL \# & SQUARE FEET & ACREAGE \\
\hline Non-Stream for Non-Stream & 182,565 & 4.190 \\
\hline
\end{tabular}

At the southern extremity of the Taylor River Placer No.1, generally located in : T.15S., R.83W., Sixth Principal Meridian, Gunnison County, Colorado Section 2: SW1/4 SW1/4 NE1/4

\begin{tabular}{|c|c|c|}
\hline PARCEL \# & SQUARE FEET & ACREAGE \\
\hline Stream for Non-Strean & 92,216 & 2.117 \\
\hline
\end{tabular}

Summary: All Non-Federal Parcels

\begin{tabular}{|c|c|c|}
\hline ALL PARCELS & SQUARE FEET & ACREAGE \\
\hline Total & 306,088 & 7.026 \\
\hline
\end{tabular}

* Acreage is approximate and will vary with the area and valuation determined from a survey and appraisal of the selected federal lands. Such lands will be amended as necessary to arrive at an equal value exchange.

Land reservations of the Non-Federal Party and exceptions to title:

Reservations: None 


\section{Attachment B. Exhibit B-Legal description of Federal lands considered in this exchange exclusive of reservations, outstanding rights, or other interests (provided by the USDA Forest Service).}

\section{EXHIBIT B}

Property that the U.S.D.A. Forest Service will consider exchanging:*

T.14S., R.83W., Sixth Principal Meridian, Gunnison County, Colorado

Sections 24, 25, 26,35

T.15S., R.83W., Sixth Principal Meridian, Gunnison County, Colorado

Section 2

Multiple parcels within and adjacent to the Taylor River stream channel at locations where the channel is not contained within the Taylor River Placer and Taylor River No. 1 Placer.

Stream for Stream Northern Federal Parcels (Taylor River Placer)

\begin{tabular}{|c|c|c|}
\hline PARCEL \# & SQUARE FEET & ACREAGE \\
\hline SH 14-1 & 14,841 & 0.341 \\
\hline SH 16-1 & 4,487 & 0,103 \\
\hline SH 17.1 & 915 & 0.021 \\
\hline SH 17-2 & 9,496 & 0.218 \\
\hline SH 18-1 & 1,437 & 0.033 \\
\hline SH 18-2 & 131 & 0.003 \\
\hline & & \\
\hline Sub-Total & $\mathbf{3 1 , 3 0 7}$ & $\mathbf{0 . 7 1 9}$ \\
\hline
\end{tabular}

Stream for Stream Southern Federal Parcels (Taylor River Placer No. 1)

\begin{tabular}{|c|c|c|}
\hline PARCEL \# & SQUARE FEET & ACREAGE \\
\hline SH 8-1 & 3,049 & 0.070 \\
\hline SH 9-1 & 1,350 & 0.031 \\
\hline SH 9-2 & 2,570 & 0.059 \\
\hline SH 10-1 & 3,659 & 0.084 \\
\hline SH 10-2;3;4,5,6 & 48,177 & 1.106 \\
\hline SH 11-1 & 33,411 & 0.767 \\
\hline & & \\
\hline Sub-Total & $\mathbf{9 2 , 2 1 6}$ & $\mathbf{2 . 1 1 7}$ \\
\hline
\end{tabular}

Non-Stream for Non-stream Federal Parcel

\begin{tabular}{|c|c|c|}
\hline PARCEL \# & SQUARE FEET & ACREAGE \\
\hline $14-2$ & 182,565 & 4.190 \\
\hline & & \\
\hline
\end{tabular}

Summary: All Federal Parcels

\begin{tabular}{|c|c|c|}
\hline ALL PARCELS & SQUARE FEET & ACREAGE \\
\hline Total & 306,088 & 7.026 \\
\hline
\end{tabular}

*Final area to be determined by BLM Cadastral Survey.

Land reservations of the U.S.D.A. Forest Service, exceptions to title and uses to be recognized: 


\title{
Attachment C. Report request (provided by the USDA Forest Service).
}

\begin{tabular}{llll} 
USDA $\begin{array}{l}\text { United States } \\
\text { Department of } \\
\text { Agriculture }\end{array}$ & $\begin{array}{l}\text { Forest } \\
\text { Service }\end{array}$ & $\begin{array}{l}\text { Rocky } \\
\text { Mountain } \\
\text { Region }\end{array}$ & $\begin{array}{l}\text { 740 Simms Street } \\
\text { Golden, CO 80401 } \\
\text { Voice: } 303-275-5350 \\
\text { TDD: } 303-275-5367\end{array}$ \\
\hline
\end{tabular} \\ File Code: $5430-2-1$ \\ Date: \\ MAR 192008 \\ Anna Wilson \\ Geologist \\ Central Mineral Resources \\ U.S. Geological Survey MS 905 \\ Box 25046 Denver Federal Center \\ Denver, CO 80225 \\ Dear Ms. Wilson: \\ The Trust under the Will of Ernest Cockrell, Jr. for the benefit of Ernest H. Cockrell, the \\ Louisiana Trust under the Will of Virginia H. Cockrell for the benefit of Ernest D. Cockrell, II, \\ and the Louisiana Trust under the Will of Virginia H. Cockrell for the benefit of David A. \\ Cockrell, 1000 Main, Suite 3250, Houston, Texas 77002 (Taylor River Land Exchange), have \\ offered certain non-Federal lands within the Gunnison National Forest, in exchange for Federal \\ lands also within the Gunnison National Forest. These lands are generally described in Exhibits \\ A and B enclosed herewith. The lands to be exchanged are depicted on the maps also provided. \\ In accordance with the working agreement under Public Law 86-509, please provide a report on \\ the locatable mineral resources on the lands described in Exhibits A and B. Please specify in \\ your report the mineral or minerals involved. Please send your report to the letterhead address. \\ If you have any questions, you may contact Nancy Hollenkamp at (303) 275-5382. \\ Sincerely,

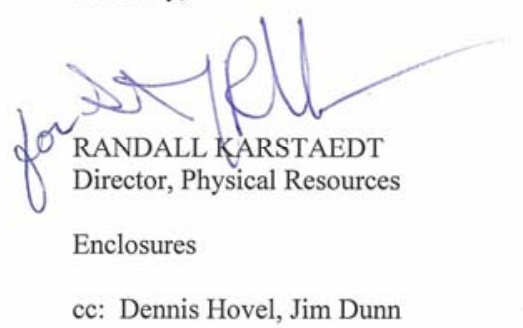




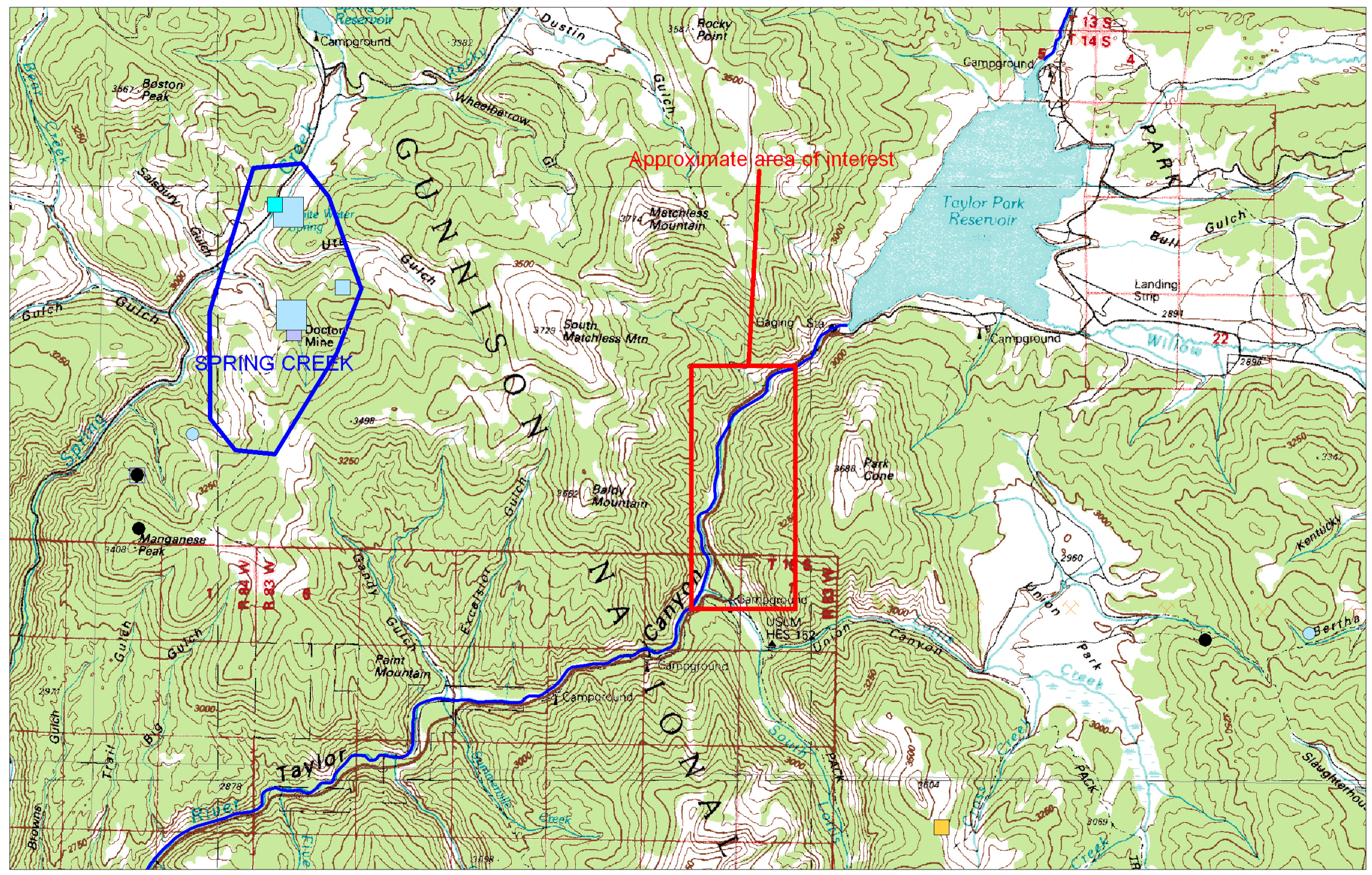

Attachment D. Index map showing approximate location of the study area. Taylor Park Reservoir is about 25 miles northeast of Gunnison. Scale 1:100,000. 


\section{LOCATABLE MINERAL REPORT FOR THE ADVENTURE EXPERIENCES LAND EXCHANGE OFFER, GRAND MESA, UNCOMPAHGRE, AND GUNNISON NATIONAL FORESTS, GUNNISON COUNTY, COLORADO}

By

Anna B. Wilson

U.S. Geological Survey

Administrative Report

January 7, 2008

The following report is based on information contained in USGS mineral resource and commodity files, mineral information databases (MRDS and MAS), and on reports and maps available in the USGS library. These data are occasionally augmented with unpublished documents, personal communications, and professional experiences. No field studies or onsite visits were performed in preparing this report. Emphasis is primarily on locatable mineral resources. Leasable and salable resources are covered only if they appear in the above documents. Mineral resource assessments are subjective: the opinions expressed herein are entirely those of the author. This report has not been reviewed for stratigraphic nomenclature. 


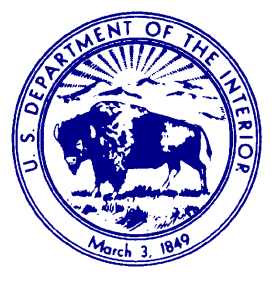

U.S. Department of the Interior

U.S. Geological Survey

Box 25046, MS 973

Denver Federal Center

Denver CO, 80225

Jan. 7, 2008

Mr. Randall Karstaedt

Director, Physical Resources

U.S. Forest Service

P.O. Box 25127

Lakewood, CO 80225-0127

Dear Mr. Karstaedt:

This report is in response to your December 3, 2007 request (received 12/5) for information on locatable mineral resources in a land exchange proposal in which Timothy and Linda Kempfe and Robert and Wilma Stump have offered certain non-Federal lands within the Gunnison National Forest in exchange for Federal lands also within the Gunnison National Forest.

In accordance with our long-term working agreement under Public Law 86-509, we are providing you with a report on the locatable mineral resources on the lands described in Exhibits A and B, which were included with your request. These lands comprise approximately 537 acres in Gunnison County, Colorado.

Sincerely yours,

Anna B. Wilson, Geologist

Mineral Resources Program, Central Region

(303) 236-5593

awilson@usgs.gov

Copies: $\quad$ C.J. Nutt

N. Hollenkamp

J. Dunn

M. Dunn

D. Hovel 
For the legal location description of lands considered for exchange refer to Exhibits $\mathrm{A}$ and $\mathrm{B}$ in Attachments A and B. The report request is Attachment C. Attachment D is a geologic map showing the approximate boundary of the non-Federal parcel (after Gaskill and others, 1987). Attachment E is a geologic map showing the approximate boundary of Federal parcels A-D (after Fridrich and others, 1998).

\section{Non-Federal Lands}

Mount Axtell 1:24,000, Paonia 1:100,000, Montrose 1:250,000 quadrangles.

The non-Federal parcel is mostly on the north-facing hillside south of Coal Creek and south of the Ruby mineralized area (Attachment D). Oligocene granodiorite porphyry and quartz monzonite porphyry (Tp) of the Mount Axtell laccolith underlies most of the parcel, except at the west end where Eocene Wasatch Formation is exposed (Gaskill and others, 1987). Along Coal Creek there are Holocene alluvial deposits (Qa) and debris and alluvial fan deposits (Qf) and Pleistocene glacial deposits (Qmy) (Gaskill and others, 1987).

According to Ed DeWitt (U.S. Geological Survey, written commun., December 17, 2007) the 30Ma laccolith is both floored and roofed by Cretaceous sedimentary rocks such as the Mesa Verde Formation and Mancos Shale. Intrusive activity at approximately 15-22 Ma was responsible for the Ag-Pb-Au-Mo vein deposits in the Ruby mineralized area.

Numerous mines and prospects in the Ruby mineralized area (Wilson, 2003) are on the hillside immediately north of the parcel and Coal Creek. Some mines in this area produced silver and associated gold, zinc, lead, and copper intermittently since 1879, though none is currently producing (Gaskill and others, 1987).

Between 1976 and 1996, 2 placer claims and 38 lode claims were closed or terminated (Wilson, 2003). There were no open claims as of 1996.

Based on the proximity to the Ruby mineralized area and the similarity of the mapped host rocks, there is moderate mineral resource potential for polymetallic vein deposits containing silver, gold, lead, zinc, copper, and associated metals such as molybdenum and tin. However, no mines or prospects of this type are within the tract, suggesting that prospectors did not see indications of ore at the surface in the parcel south of the creek. If there are buried intrusions at depth, the potential exists for concealed porphyry molybdenum deposits, similar to those at Mount Emmons (several miles to the north). Resource potential for such deposits is moderate (Ed DeWitt, written commun., December 17, 2007). 


\section{Federal Lands}

Parcels A, B, C, and D

Pieplant 1:24,000, Gunnison 1:100,000, Montrose 1:250,000 quadrangles.

Parcels A-D (Attachment E) are primarily in Pleistocene glacial deposits (Qg) and in Holocene surficial deposits (Qs) (Fridrich and others, 1998). In Illinois Creek, in the southernmost part of the parcel, Middle Proterozoic Granite of Taylor River (Yt) and Early Proterozoic Granite of Henry Mountain (Xh) may be exposed. Parcel D has exposures of Proterozoic Granite of Taylor River (Yt) and Early Proterozoic metasdimentary gneiss and quartzite $(\mathrm{Xq})$ showing through the glacial deposits (Qg) along its length.

Besides placer gold in the general vicinity of Taylor Park and Taylor River (Davis and Streufert, 1990; Parker, 1974), no mines are known in similar host rocks in the vicinity. The source of the placer gold was from the north and northwest (Ed DeWitt, written commun., December 17, 2007). South of the parcels the gold placers come from vein deposits farther south of Taylor Park. Published information relating to the "prospects" labeled on the Pieplant topographic map east of Parcel A and immediately beyond the northeast end of Parcel D was not discovered during a reasonably thorough literature search.

From 1976 through 1996 there were no open claims of any kind in sections 26-28, where the main bodies of the parcels lie. In all, one lode claim, one tunnel claim, and 17 placer claims were closed during that time period (Wilson, 2003).

Mineral resource potential for placer gold is low as there are no known vein deposits upstream (Ed DeWitt, written commun., December 17, 2007). Resource potential is low for all other locatable minerals. There are significant well-sorted outwash deposits on the parcels that could have potential for sand and gravel, a salable resource.

\section{LIST OF ATTACHMENTS:}

A. Exhibit A. Legal description of non-Federal land considered in this exchange (provided by the USDA Forest Service) exclusive of Reservations and Outstanding Rights.

B. Exhibit B. Legal description of Federal land considered in this exchange (provided by the USDA Forest Service) exclusive of Reservations and Outstanding Rights.

C. Report request (provided by the USDA Forest Service).

D. Geologic map showing the approximate boundary of the non-Federal parcel (after Gaskill and others, 1987).

E. Geologic map showing the approximate boundary of Federal parcels A-D (after Fridrich and others, 1987). 


\section{REFERENCES:}

Davis, M.W., and Streufert, R.K., 1990, Gold occurrences of Colorado: Colorado Geological Survey Resource Series 28, 101 p.

Fridrich, C.J.; DeWitt, Ed; Bryant, Bruce; Richard, Steve; and Smith, R.P., 1998, Geologic map of the Collegiate Peaks Wilderness Area and the Grizzly Peak Caldera, Sawatch Range, central Colorado: U.S. Geological Survey Miscellaneous Investigations Series Map I-2565, scale 1:50,000.

Gaskill, D.L., DeLong, J.E., Jr., and Cochran, D.M., 1987, Geologic map of the Mt. Axtell quadrangle, Gunnison County, Colorado: U.S. Geological Survey Geologic Quadrangle Map GQ-1604, scale 1:24,000 and 7 p. pamphlet.

Parker, B.H., Jr., 1974, Gold placers of Colorado: Colorado School of Mines Quarterly, v. 69, no. 4, book 2 of 2, p. 102.

Wilson, A.B., 2003, Databases and simplified geology for mineralized areas, claims, mines and prospects in Colorado: U.S. Geological Survey Open-File Report 2003-90, available at. [http://pubs.usgs.gov/of/2003/ofr-03-090/]. 


\title{
Attachment A. Exhibit A-Legal description of non-Federal land considered in this exchange (provided by the USDA Forest Service).
}

\author{
EXHIBIT A
}

Property that the Non-Federal Party will consider exchanging:

Sixth Principal Meridian, Gunnison County, Colorado

T. 14 S..., R. $87 \mathrm{~W}$. Section 11: N1/2SE1/4, E1/2SW1/4NE1/4, NE1/4SW1/4, E1/2NW1/4SW1/4

Containing160 acres, more or less.

Land reservations of the Non-Federal Party and exceptions to title:

Reservations: None

Outstanding Rights

1. Reservations or exceptions, or an act authorizing the issuance thereof, as created by United States Patents recorded in Book 101 at Page 259, and in Book 101 at Page 479.

2. Lease of Right of Way between Crested Butte and Kebler Pass as recorded June 3, 1932 in Book 241 at Page 410.

3. Sewer Installation and Inspection Agreement recorded November 15, 1978 in Book 523 at Page 988 and assignment of Contract Rights recorded December 19, 1991 in Book 699 at Page 395.

4. Easement recorded September 19, 1979 in Book 539 at Page 548.

5. Easement between United States of America and Gunnison County Commisioners recorded June 15, 1982 in Book 580 at Page 702.

6. Easement and right of way for Kebler Pass Road.

7. (a) All right, title or claim or any character by the United States, state, local government or by the public generally in and to any portion of the land lying within the current or former bed of Coal Creek, or below the ordinary high water mark, or between the cut banks of a stream navigable in fact or in law. (b) Right of riparian water rights owners to the use and flow of the water. (c) The consequence of any past or future change in the location of the bed. 


\section{Attachment B. Exhibit B-Legal description of Federal land considered in this exchange (provided by the USDA Forest Service).}

\section{EXHIBIT B}

Property that the U.S.D.A. Forest Service will consider exchanging:

\section{Sixth Principal Meridian, Gunnison County, Colorado}

Parcel A:

T. 13 S., R. $82 \mathrm{~W}$.

Sec. 27 , portion of the $\mathrm{W} 1 / 2$;

Sec. 28, portion of the SE1/4.

Totaling 120 acres, more or less.

Parcel B:

T. 13 S., R. $82 \mathrm{~W}$.

Sec. 27, portion.

Totaling 82 acres, more or less.

Parcel C:

T. 13 S., R. $82 \mathrm{~W}$.

Sec. 26, portion of the $S 1 / 2$., portion of the NE1/4.

Totaling 132.5 acres, more or less.

Parcel D:

T. 13 S., R. 82 W.

Sec. 23, portion of the SE1/4;

Sec. 24, portion of the SW1/4;

Sec. 25, portion of the N1/2.

Totaling 42.5 acres, more or less.

All totaling 377 acres, more or less.

Land reservations of the U.S.D.A. Forest Service, exceptions to title and uses to be recognized:

Reservations:

1. Reserving to the United States a right-of-way thereon for ditches or canals constructed by the authority of the United States Act of August 30, 1890 (26 Stat. 391; 43 U.S.C. 845).

Outstanding Rights: None

Other: 


\section{Attachment C. Report Request (provided by the USDA Forest Service).}

\section{USDA United States

Department of

$\begin{array}{ll}\text { Forest } & \text { Rocky } \\ \text { Service } & \text { Mountain } \\ & \text { Region }\end{array}$

740 Simms Street

Golden, CO 80401

Voice: 303-275-5350

TDD: 303-275-5367

Anna Wilson

File Code: $5430-2-1$

Date:

Geologist

U.S. Geological Survey MS 905

Central Mineral Resources

Box 25046, Denver Federal Center

Denver, CO 80225

Dear Ms. Wilson:

Timothy G. and Linda D. Kempfe, husband and wife, of 517 Mallard Lane, Trinity, Texas, and Robert C. and Wilma D. Stump, husband and wife, of 630 Stump Lane, DeRidder, Louisiana (Adventure Experiences exchange), have offered certain non-Federal lands within the Gunnison National Forest, in exchange for Federal lands also within the Gunnison National Forest. These lands are generally described in Exhibits A and B enclosed herewith. The lands to be exchanged are depicted on the maps also provided.

In accordance with the working agreement under Public Law 86-509, please provide a report on the locatable mineral resources on the lands described in Exhibits A and B. Please specify in your report the mineral or minerals involved. Please send your report to the letterhead address.

If you have any questions, you may contact Nancy Hollenkamp at (303) 275-5382.

Sincerely,

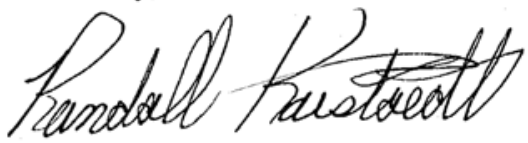

RANDALL KARSTAEDT

Director, Physical Resources

Enclosures

cc: Dennis Hovel, Jim Dunn 


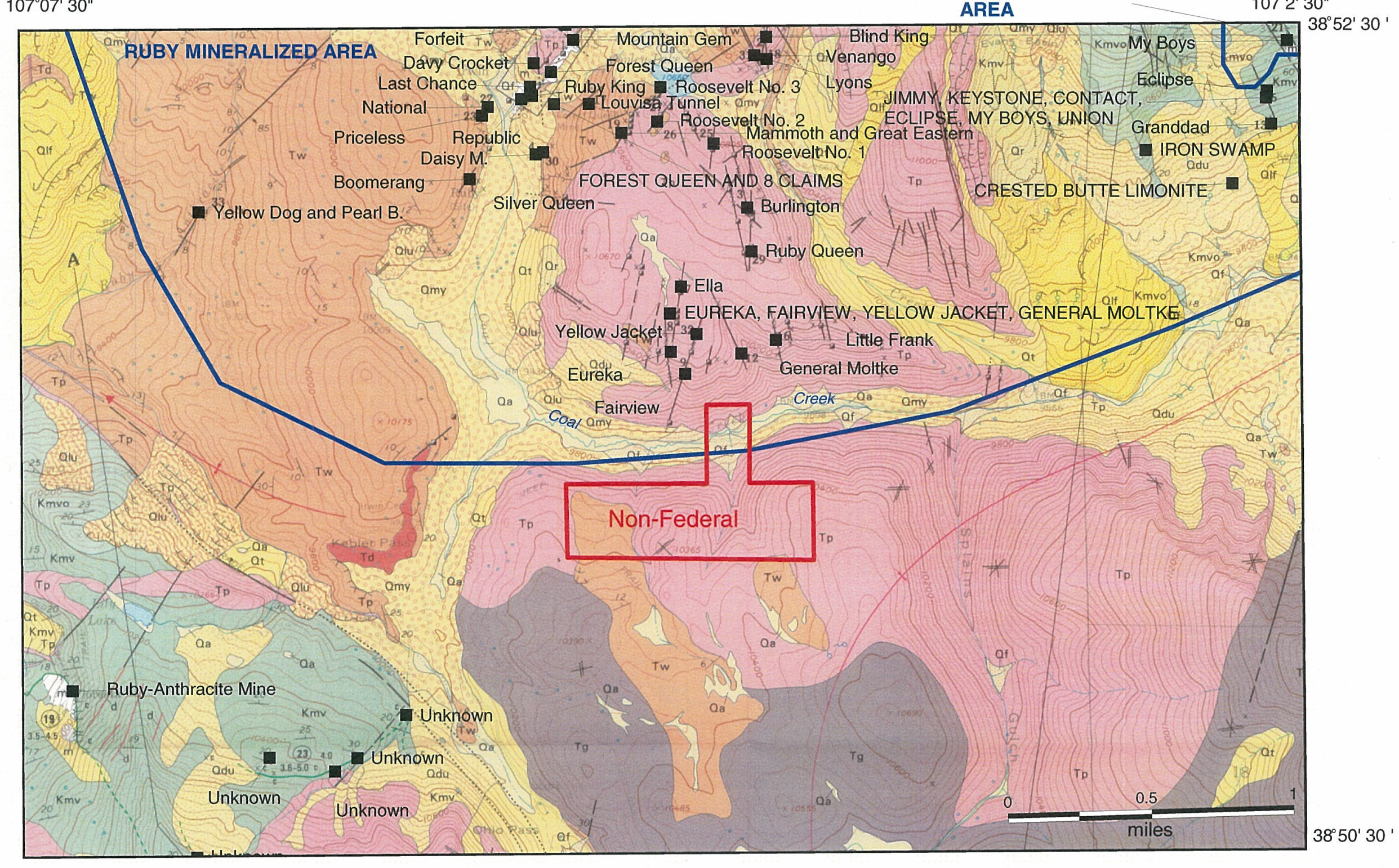

Attachment D. Geologic map showing the approximate boundary of the non-Federal parcel (after Gaskill and others, 1987). Qa, Holocene alluvial deposits; Qf, Holocene debris and fan deposits; Qmy, Pleistocene glacial deposits; Tp, Oligocene granodiorite porphyry and quartz monzonite porphyry; Tw, Eocene Wasatch Formation. Mine locations from Wilson (2003, and unpublished data). For other map units not exposed in the parcel, refer to Gaskill and others (1987). Approximate scale 1:31,250. 


\section{LOCATABLE MINERAL REPORT FOR THE \\ HERMOSA PARK/MITCHELL LAKES LAND EXCHANGE OFFER, SAN JUAN NATIONAL FOREST, LA PLATA COUNTY, COLORADO}

By

Anna B. Wilson

U.S. Geological Survey

Administrative Report

September 20, 2007

The following report is based on information contained in USGS mineral resource and commodity files, mineral information databases (MRDS and MAS), and on reports and maps available in the USGS library. These data are occasionally augmented with unpublished documents, personal communications, and professional experiences. No field studies or onsite visits were performed in preparing this report. Emphasis is primarily on locatable mineral resources. Leasable and salable resources are covered only if they appear in the above documents. Mineral resource assessments are subjective: the opinions expressed herein are entirely those of the author. This report has not been reviewed for stratigraphic nomenclature. 


\author{
U.S. Department of the Interior \\ U.S. Geological Survey \\ Box 25046, MS 973 \\ Denver Federal Center \\ Denver CO, 80225
}

August 23, 2007

Mr. Randall Karstaedt

Director, Physical Resources

U.S. Forest Service

P.O. Box 25127

Lakewood, CO 80225-0127

Dear Mr. Karstaedt:

This report is in response to your June 26 request (received 7/10) for information on locatable mineral resources in a land exchange proposal in which Tamarron Properties Associates, LLC, has offered certain non-Federal lands within the San Juan National Forest in exchange for Federal lands also within the San Juan National Forest.

In accordance with our long-term working agreement under Public Law 86-509, we are providing you with a report on the locatable mineral resources on the lands described in Exhibits A and B, which were included with your request. These lands comprise approximately 595.2 acres in La Plata County, Colorado.

Sincerely yours,

Anna B. Wilson, Geologist

Mineral Resources Program, Central Region

(303) 236-5593

awilson@usgs.gov

Copies: $\quad$ C.J. Nutt

N. Hollenkamp

M. Dunn 
For the legal location description of lands considered for exchange exclusive of Reservations, Outstanding Rights, or other restrictions, refer to Exhibits A and B in Attachments A and B. The report request is Attachment $\mathrm{C}$. Attachment $\mathrm{D}$ is a parcel location map overview. Attachments $\mathrm{E}-\mathrm{G}$ are geologic maps showing the approximate locations of the parcels.

\section{Non-Federal Lands}

\section{Parcel 1 - Hermosa Park}

Hermosa Peak 1:24,000, Silverton 1:100,000, Durango 1:250,000 quadrangles.

Most of the Hermosa Park parcel is in the valley bottom, at the confluence of East Fork and Hermosa Creeks. With the exception of the upper member of the Middle Pennsylvanian Hermosa Group (IPhu; Hermosa Formation on Pratt, 1976) exposed on the valley walls and capped by lower Permian Cutler Formation (Pc) in the northeastern-most corner, the parcel is almost entirely Quaternary alluvium and glacial drift (Qal, Qd; Pratt, 1976; Attachment E). An inferred lineament with no geological expression, was mapped in the northwestern corner in the Hermosa Group (Pratt, 1976).

No mines are known within almost 6 miles of the parcel (Wilson, 2003; A.B. Wilson, U.S. Geological Survey, unpublished data, 2007). The nearest mineral deposits are nearly 6 miles to the northwest in the Rico area and approximately 6 miles to the east in the Cascade district.

In their mineral resource assessment of the San Juan National Forest, Van Loenen and Gibbons (1997) did not assign this area any locatable resource potential because it does not have geology conducive to these types of deposits. Therefore, mineral resource potential for locatable minerals is low. However, the parcel is within the Silverton Delta play (Van Loenen and Gibbons, 1997), which may have conventional accumulations of oil and gas in permeable deltaic sandstones.

\section{Parcel 2 - Mitchell Lakes}

Hermosa 1:24,000, Durango 1:100,000, Durango 1:250,000 quadrangles.

Mapping by Gonzales and others (2003b; Attachment F) shows the Mitchell lakes parcel almost entirely underlain by Middle Pennsylvanian Hermosa Group (IPh) and covered, with the exception of the steeper western and southern slopes, by Quaternary landslide, alluvium and colluvium, and glacial (moraine and dammed tributary) deposits (Qls, Qac, Qm, and Qdts).

No mines are known on the parcel (Wilson, 2003; A.B. Wilson, U.S. Geological Survey, unpublished data, 2007), but there is an unknown prospect shown on the topographic map about 600 feet west of the northwestern corner of the parcel in Hermosa Group. There are no data on this "prospect" in the USGS minerals databases, however, it is stratigraphically at the same position as the Tripp Gulch uranium prospect, approximately 3 1/2 miles south-southwest of the parcel. Such a deposit, if it exists in this area, would be stratigraphically above the parcel, and therefore there would not be resource potential on the property. Hot springs and placer claims may be located 3/4 to 1 1/2 miles east to southeast of the parcel; similar geologic settings to these are not present on the parcel. 
The parcel is east of the tract assigned potential for sandstone uranium deposits in Rico Formation (Tract I2 of Van Loenen and Gibbons, 1997). Rico Formation is mapped on the State-scale (Tweto, 1979) and 1:250,000-scale San Juan National Forest map (Van Loenen and Gibbons, 1997) above the Hermosa Group. Rico Formation was not recognized on the 1:24,000 Hermosa quadrangle map (Gonzales and others, 2003b). Lack of Rico Formation would suggest mineral resource potential for locatable minerals is low. However, the parcel is within the Silverton Delta play (Van Loenen and Gibbons, 1997), which may have conventional accumulations of oil and gas in permeable deltaic sandstones.

\section{Federal Lands}

near Chris Park Campground

Electra Lake 1:24,000, Silverton 1:100,000, Durango 1:250,000 quadrangles.

Recent mapping by Gonzales and others (2003a; Attachment G) shows Paleoproterozoic (1.8$1.69 \mathrm{Ga}$ ) Irving Formation exposed in the eastern part of the parcel. Unconformably overlying this oldest unit is the Upper Cambrian Ignacio and Upper Devonian Elbert Formations, undivided (DCei). Upper Devonian Ouray Limestone (Do), Lower Mississippian Leadville Limestone (Ml), and small remnants of Lower Pennsylvanian Molas Formation (IPm) cap off the stratigraphic sequence. The entire area is thinly covered with glacial till. Quaternary alluvium (Qa) fills the valley on the west side of the parcel concealing probable faults. A fault, with approximately 150 to 220 feet of apparent offset, dropped down to the north, bisects the parcel.

No mines are known in the vicinity of the parcel (Wilson, 2003; A.B. Wilson, U.S. Geological Survey, unpublished data, 2007). In their mineral resource assessment of the San Juan National Forest, Van Loenen and Gibbons (1997) did not assign this area any locatable resource potential. Therefore, mineral resource potential for locatable minerals is low. 


\section{LIST OF ATTACHMENTS:}

A. Exhibit A. Legal description of Non-Federal land considered in this exchange (provided by the USDA Forest Service).

B. Exhibit B. Legal description of Federal land considered in this exchange (provided by the USDA Forest Service).

C. Report request (provided by the USDA Forest Service).

D. Parcel location map.

E. Geologic map showing approximate location of non-Federal Hermosa Creek parcel (after Pratt, 1976; A.B. Wilson, U.S. Geological Survey, unpublished data, 2007).

F. Geologic map showing approximate location of non-Federal Mitchell Lakes parcel (after Gonzales and others, 2003a; A.B. Wilson, U.S. Geological Survey, unpublished data, 2007).

G. Geologic map showing approximate location of Federal Chris Park parcel (after Gonzales and others, 2003b; A.B. Wilson, U.S. Geological Survey, unpublished data, 2007).

\section{REFERENCES:}

Gonzales, D.A., Stahr, D.W., III, Frechette, J.D., Dorin, F., Costello, K., Cullicott, C., Kolody, R., Remley, K., and Graham, K., 2003a, Geologic map of the Electra Lake 7.5-minute Quadrangle, La Plata County, Colorado: Colorado Geological Survey Open-File Report 03-21, scale 1:24,000.

Gonzales, D.A., Stahr, D.W., III, and Kirkham, R.M., 2003b, Geologic map of the Hermosa Quadrangle, La Plata County, Colorado: Colorado Geological Survey Open-File Report 02-01, scale 1:24,000.

Neubert, J.T., Ellis, C.E., Hannigan, B.J., Jeske, R.E., Martin, C.M., Thompson, J.R., Tuftin, S.E,.Wood, R.H., II, Zelten, J.E., 1992, Mineral appraisal of the San Juan National Forest, Colorado, with a section on Industrial Minerals by Raby, A.G.: U.S. Bureau of Mines Mineral Land Assessment Open-File Report MLA-2-92, 311 p.

Pratt, W.P., 1976, Preliminary geologic map of the Hermosa Peak Quadrangle, Dolores, San Juan, La Plata, and Montezuma counties, Colorado: U.S. Geological Survey Open-File Report 76-314, scale 1:24,000.

Tweto, Ogden, 1979, Geologic Map of Colorado: U.S. Geological Survey, scale 1:500,000.

Van Loenen, R.E., and Gibbons, A.B., eds., 1997, Mineral resource potential and geology of the San Juan National Forest, Colorado, with a section on Salable Minerals by Raby, A.G. and Dersch, J.S.: : U.S. Geological Survey Bulletin 2127, 140 p.

Wilson, A.B., 2003, Databases and simplified geology for mineralized areas, claims, mines and prospects in Colorado: U.S. Geological Survey Open-File Report 2003-90. 
Attachment A. Exhibit A-Legal description of non-Federal land considered in this exchange (provided by the USDA Forest Service).

\section{$\underline{\text { EXHIBIT A }}$}

Property that the Non-Federal Party will consider exchanging:

New Mexico Principal Meridian, La Plata County, Colorado

Non-Federal Parcel 1 - Hermosa Park:

T. 39 N., R. 10 W.

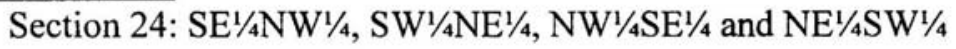

Containing 160 acres, more or less.

Non-Federal Parcel 2 - Mitchell Lakes:

T. 37 N., R. 9 W. Section 23: SE1/4NW1/4, SW1/4NE1/4, NW1/4SE1/4 and NE $1 / 4 \mathrm{SW}^{1 / 4}$.

Containing160 acres, more or less.

Containing an aggregate of 320.0 acres, more or less.

Land reservations of the Non-Federal Party and exceptions to title:

Reservations: None

$\underline{\text { Outstanding Rights }}$

1. Right of way for the Hermosa Park Truck Trail \#732 Road set forth and described in Right of Way Deed to the United States of America recorded November 30, 1953 in Book 318 at Page 389. (Affects Non-Federal Parcel 1 - Hermosa Park)

2. Trail easement as described in Easement to the United States of America recorded August 5, 1980 as Reception No. 445582. (Affects Non-Federal Parcel 1-Hermosa Park) 
Attachment B. Exhibit B--Legal description of Federal land considered in this exchange(provided by the USDA Forest Service).

EXHIBIT B

Property that the U.S.D.A. Forest Service will consider exchanging:

New Mexico Principal Meridian, La Plata County, Colorado

T. 38 N., R. 9 W.

Section 36: $\mathrm{S}^{1} / 2 \mathrm{~N}^{1} / 2 \mathrm{NE}^{1} / 4 \mathrm{SE}^{1} / 4, \mathrm{~S}^{1} / 2 \mathrm{~N}^{1} / 2 \mathrm{SE}^{1} / 4, \mathrm{~S}^{1} / 2 \mathrm{SE}^{1} / 4, \mathrm{SE}^{1} / 4 \mathrm{SW}^{1} / 4, \mathrm{~S}^{1} / 2 \mathrm{NE}^{1} / 4 \mathrm{SW}^{1} / 4$ and $\mathrm{S}^{1} / 2 \mathrm{NE}^{1 / 4} \mathrm{NE}^{1 / 4} / \mathrm{SW}^{1 / 4}$.

T. 37 N., R. 9 W.

Section 1: Lots 1, 5 and 7

Containing 275.2 acres, more or less.

Land reservations of the U.S.D.A. Forest Service, exceptions to title and uses to be recognized:

\section{Reservations:}

1. Reserving to the United States a right-of-way thereon for ditches or canals constructed by the authority of the United States Act of August 30, 1890 (26 Stat. 391; 43 U.S.C. 845).

Outstanding Rights: None

Other:

1. Special Use Permit (Class D Road Permit) issued to Donald and Alberta Brown for an existing road. The Forest will obtain a waiver/relinquishment at or prior to closing. The non-Federal party will be required to issue an easement replacing this permit at closing.

2. Special Use Permit issued to La Plata Electric for existing power line. The Forest will obtain a waiver/relinquishment/amendment for any portion of the permit affected by the exchange at or prior to closing. The non-Federal party will be required to issue an easement replacing the same at closing.

3. Special Use Permit issued to Qwest for existing buried phone line. The Forest will obtain a waiver/relinquishment/amendment for any portion of the permit affected by the exchange at or prior to closing. The non-Federal party will be required to issue an easement replacing the same at closing.

4. At or before closing the non-Federal party will secure relinquishment of the FLPMA private road and Forest Road easements (COL5450-01 and COL5450-02) both issued to William and Beverly Ridgeway on September 25, 1996. 
Attachment C. Report Request (provided by the USDA Forest Service).

\begin{tabular}{llll} 
USDA United States & Forest & Rocky & P.o. Box 25127 \\
Department of & Service & Mountain & Rakewood, CO 80225-0127 \\
Agriculture & & Region & Delivery: 740 Simms Street \\
& & Golden, CO 80401 \\
& & Voice: 303-275-5350 \\
& & TDD: 303-275-5367 \\
\hline
\end{tabular}

File Code: $5430-2-1$

Date:

JUN 262007

Anna Wilson, Geologist

Central Mineral Resources

U.S. Geological Survey MS 905

Box 25046 Denver Federal Center

Denver, CO 80225

Dear Ms. Wilson:

Tamarron Properties Associates, LLC, a Colorado limited liability company, of PO Box 3131, Durango, Colorado, has offered certain non-Federal lands within the San Juan National Forest, in exchange for Federal lands also within the San Juan National Forest. These lands are generally described in Exhibits A and B enclosed herewith. The lands to be exchanged are depicted on the maps, also provided.

In accordance with the working agreement under Public Law 86-509, please provide a report on the locatable mineral resources on the lands described in Exhibits A and B. Please specify in your report the mineral or minerals involved. Please send your report to the letterhead address.

If you have any questions, you may contact Nancy Hollenkamp at (303) 275-5382.

Sincerely,

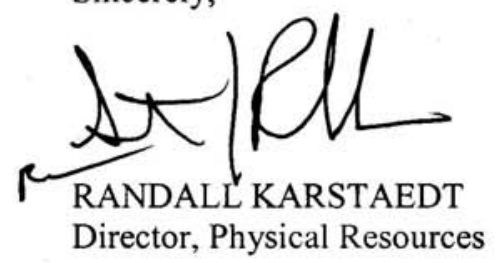

Enclosures

cc: Cindy Hockelberg 
Attachment D. Parcel location map. Locations shown on Durango 2 degree topographic map. Figure is not to scale.

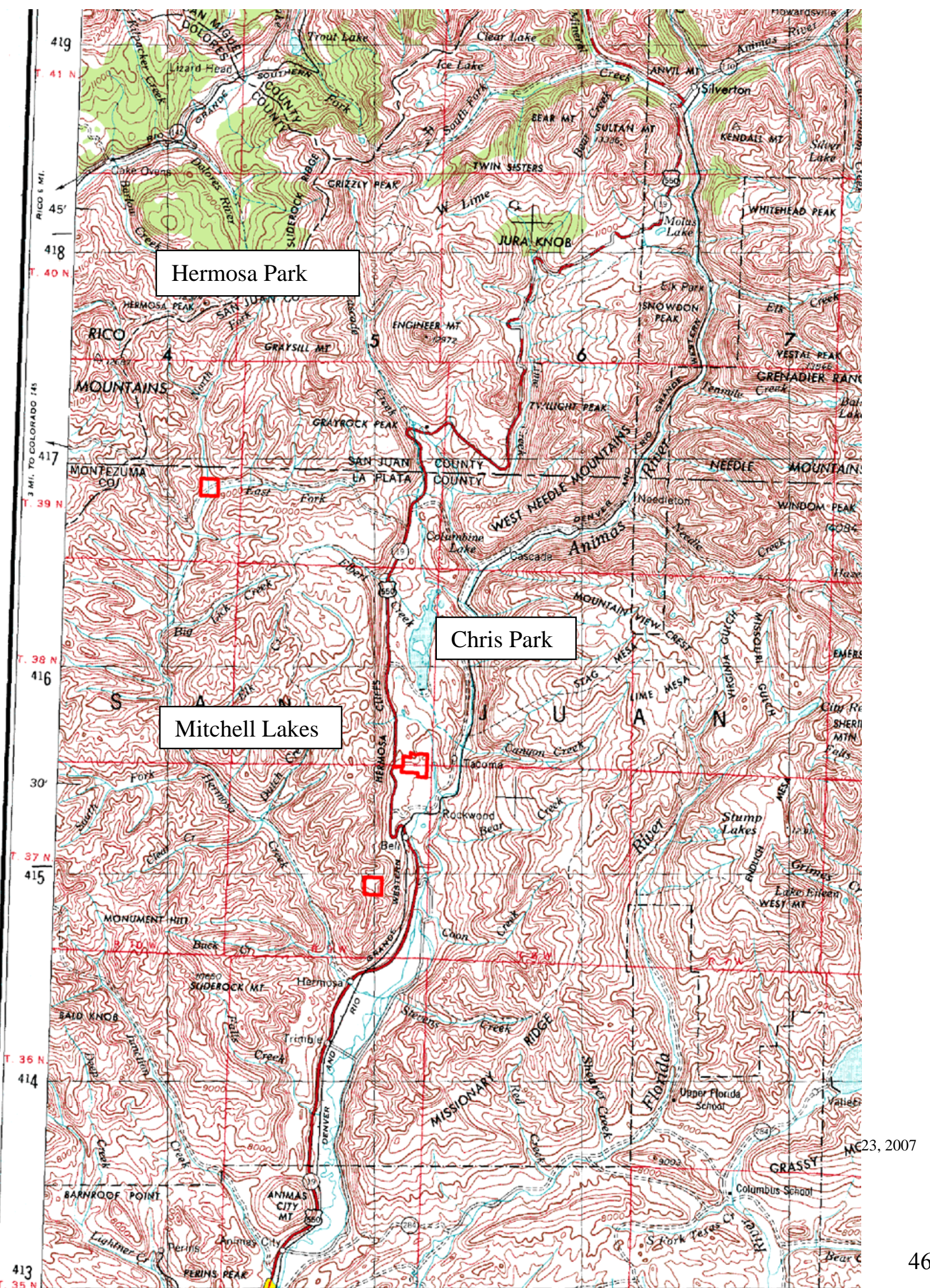




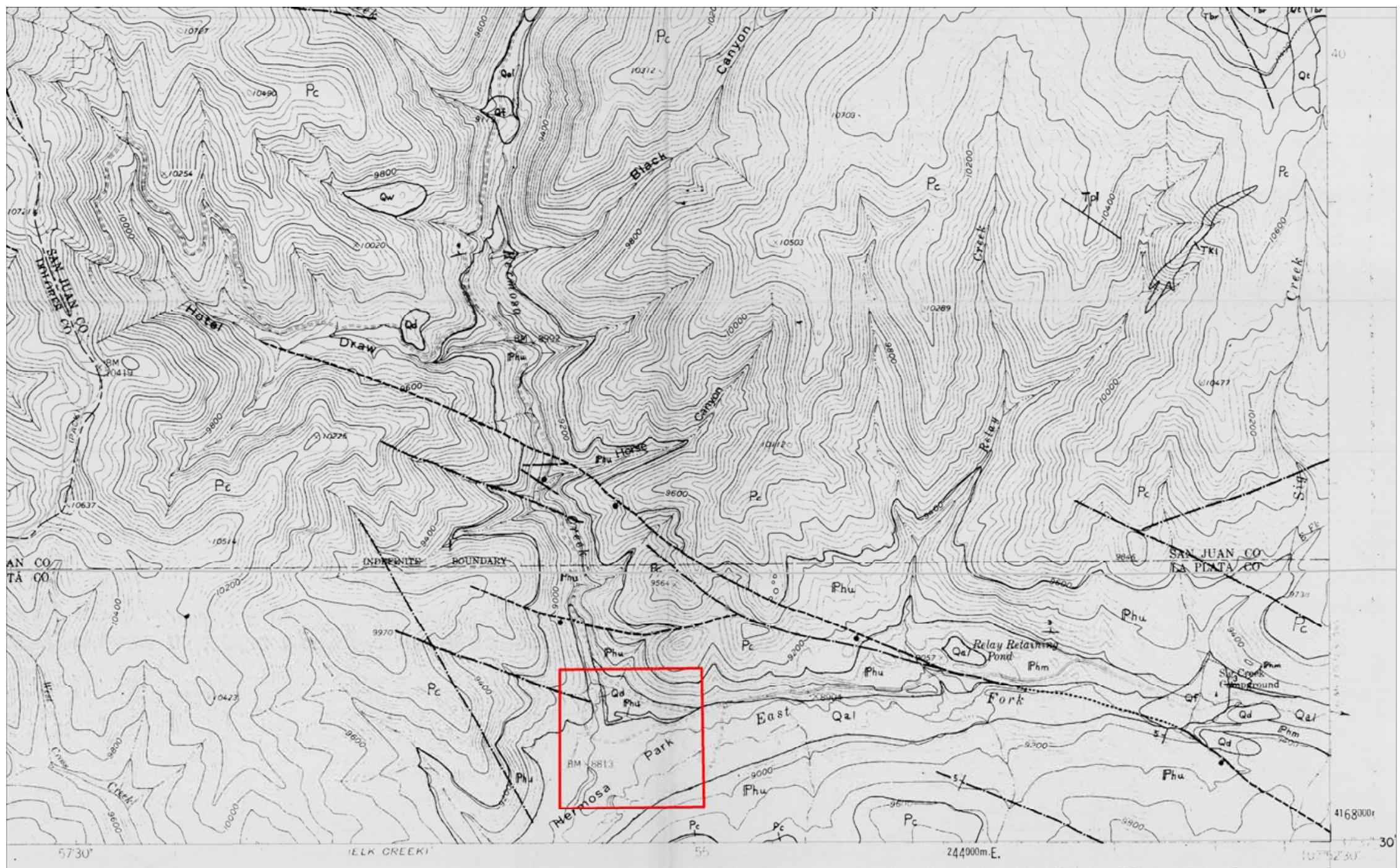

Attachment E. Geologic map showing approximate location of non-Federal Hermosa Park parcel (after Pratt, 1976; A.B. Wilson, U.S. Geological Survey, unpublished data, 2007). 
Attachment F. Geologic map showing approximate location of non-Federal Mitchell Lakes parcel (after Gonzales and others, 2003b; A.B. Wilson, U.S. Geological Survey, unpublished data, 2007).

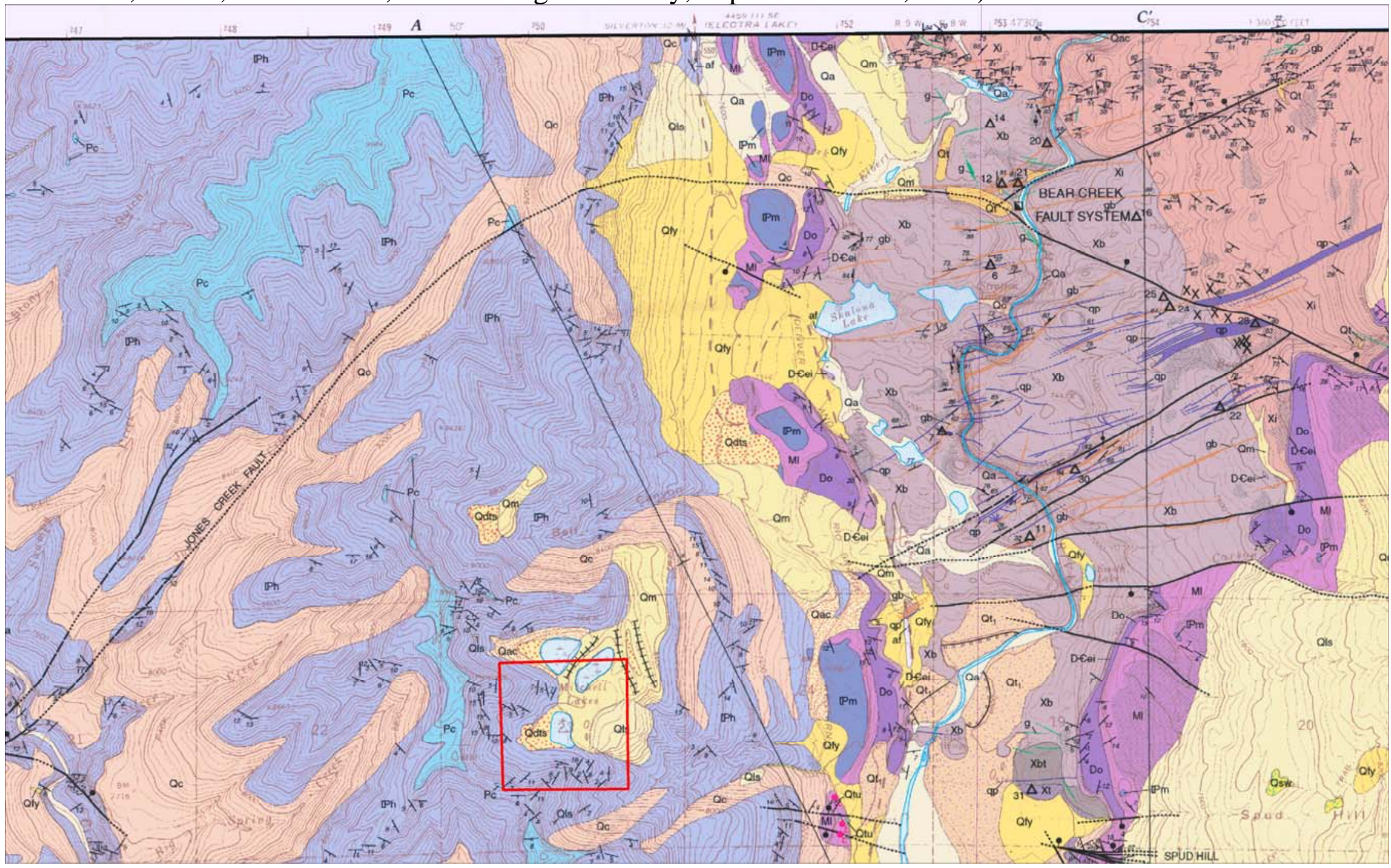


Attachment G. Geologic map showing approximate location of Federal parcel near Chris Park Campground (after Gonzales and others, 2003a; A.B. Wilson, U.S. Geological Survey, unpublished data, 2007).

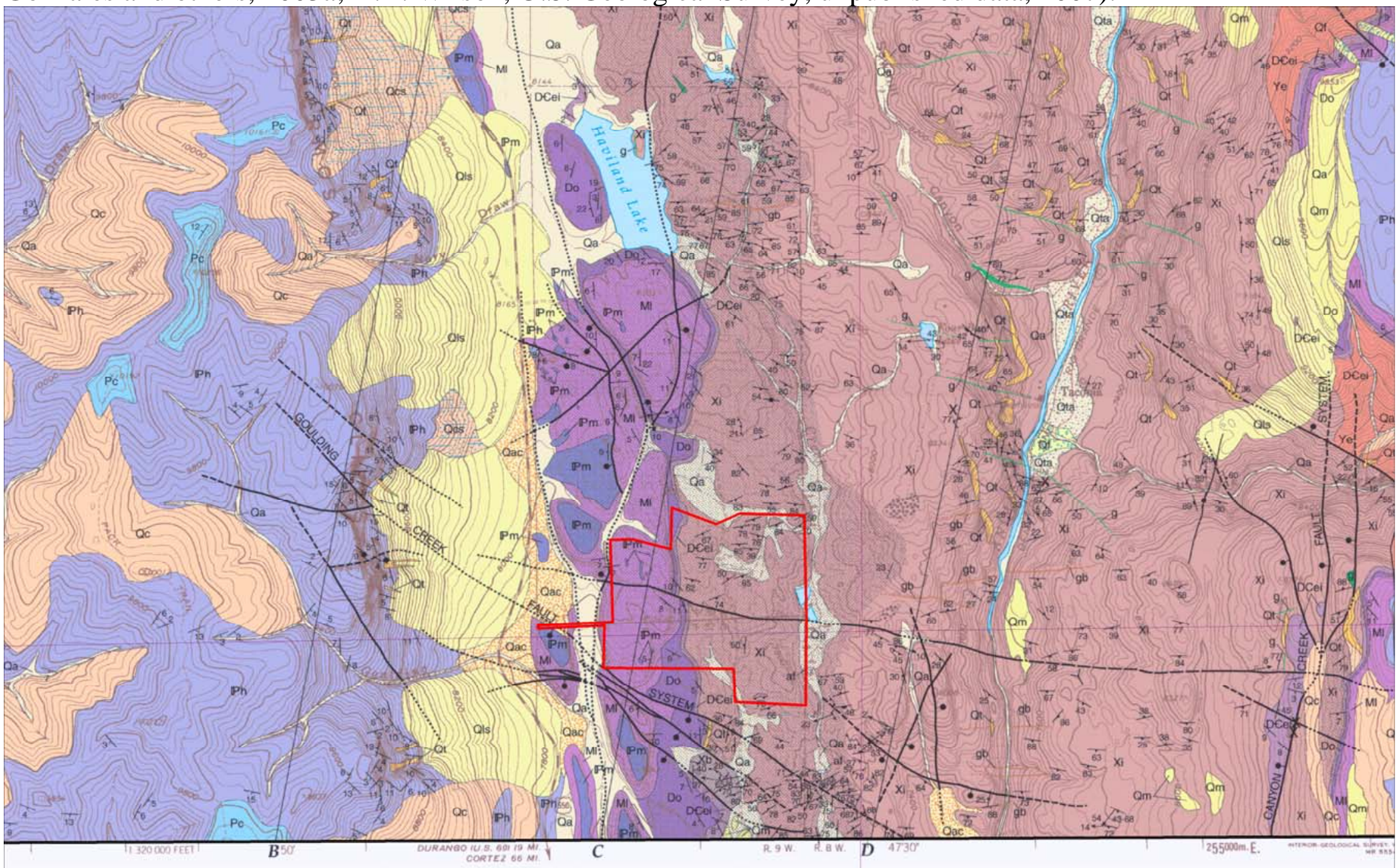




\section{LOCATABLE MINERAL REPORT FOR THE \\ BANDED PEAK RANCHES MINERAL EXCHANGE OFFER, RIO GRANDE AND SAN JUAN NATIONAL FORESTS, ARCHULETA COUNTY, COLORADO}

By

Anna B. Wilson

U.S. Geological Survey

Administrative Report

March 3, 2006

The following report is based on information contained in USGS mineral resource and commodity files, in mineral information databases (MRDS and MAS), and on reports and maps available in the USGS library. These data are occasionally augmented with unpublished documents, personal communications, and professional experiences. No field studies or on-site visits were performed in preparing this report. Emphasis is primarily on locatable mineral resources. Leasable and salable resources are covered only if they appear in the above documents. Mineral resource assessments are subjective: the opinions expressed herein are entirely those of the author. This report has not been reviewed for stratigraphic nomenclature. Any use of trade, product, or firm names is for descriptive purposes and does not imply endorsement by the U.S. Government. 


\title{
U.S. Department of the Interior
}

\author{
U.S. Geological Survey \\ Box 25046, MS 905 \\ Denver Federal Center \\ Denver CO, 80225
}

February 13, 2006

Mr. Randall Karstaedt

Director, Physical Resources

U.S.D.A. Forest Service

P.O. Box 25127

Lakewood, CO 80225-0127

Dear Mr. Karstaedt:

This report is in response to your January 30 (received February 13) request for information on locatable mineral resources in a mineral exchange proposal in which Catspaw Ranch and Navajo Headwaters have offered certain non-Federal minerals within the Rio Grande National Forest, in exchange for Federal minerals within the Rio Grande and San Juan National Forests.

In accordance with our long-term working agreement under Public Law 86-509, we are providing you with a report on the locatable mineral resources on the lands described in Exhibits $\mathrm{A}$ and B, which were included with your request. These lands comprise approximately 35,900 acres in Archuleta County, Colorado.

Sincerely yours,

Anna B. Wilson, Geologist

Mineral Resources Program, Central Region

Copies: C.J. Nutt

R. Baer

N. Hollenkamp

:... locmin \locmin90.wpd 
For the legal location description of lands considered for exchange, refer to Exhibits A and B in Attachments A and B. The report request is Attachment C. Attachment D is a geologic map showing the approximate locations of the parcels.

\section{$\underline{\text { Non-Federal Mineral Estate in Rio Grande NF }}$}

\section{Parcel 1 (TractA, Exhibit A)}

Archuleta Creek, Chama Peak, Victoria Lake 1:24,000; Chama Peak 1:62,500; Antonito 1:100,000, Durango 1:250,000 quadrangles.

Parcel 1 is underlain by a succession of Cretaceous Mancos Shale and Eocene Blanco Basin Formation (Lipman and Hail, 1975). Various Oligocene volcanic units including volcaniclastic and vent facies of the Conejos Formation and tuffs in ash-flow sheets overlie the sedimentary rocks (Lipman and Hail, 1975; Brock and Gaskill, 1985). Most of the overlying Quaternary deposits are Holocene and Pleistocene landslides. Locally there are glacial moraines and alluvium.

All of Parcel 1 is on Federal lands in the Rio Grande National Forest; however, the Federal Government does not possess the mineral rights. Most of the area included in Parcel 1 is part of the Chama-southern San Juan Mountains wilderness study area that was previously assessed for mineral resource potential by the U.S. Geological Survey and U.S. Bureau of Mines (U.S. Geological Survey and U.S. Bureau of Mines, 1985). In the course of that assessment, no indication of mineralization was found in the area included in Parcel 1. According to USGS mineral resource databases (Wilson, 2003; Wilson, unpub. data, 2006), there are no mines in or near Parcel 1. The closest resource of any kind is a sand and gravel pit (salable minerals) more than 2 miles to the east. Mineral resource potential for all locatable commodities is low.

\section{Federal Mineral Estate on Private lands in San Juan NF}

\section{Parcel A}

Elephant Head Rock, Chama Peak, Harris Lake 1:24,000; Chama Peak, Chromo 1:62,500; Antonito 1:100,000, Durango 1:250,000 quadrangles.

Parcel A is primarily mapped as early intermediate composition lavas, vent, and volcaniclastic facies of the Oligocene Conejos Formation (Lipman and Hail, 1975). The volcanic rocks overlie Upper Cretaceous Lewis Shale, exposed near the southern end of the Parcel between Pete and Aspen Creeks and between Navajo Peak and Banded Peak Ranch. Several small Pliocene to Oligocene dikes and plugs of varied compositions intrude the volcanic sequence and are exposed near the central part of the Parcel. Most of the central and southeastern part of the parcel is covered with Holocene and Pleistocene landslide deposits. Deposits of Quaternary alluvium follow the Navajo River and there are localized deposits of colluvium (Lipman and Hail, 1975). 
Parcel A is entirely Non-Federal land within the San Juan National Forest. The Federal government owns the mineral rights. This area is included in the mineral resource assessment of the San Juan National Forest (Van Loenen and Gibbons, 1997), and is just outside the boundary of the Chama-southern San Juan wilderness study area (USGS and USBM, 1985).

The Banded Peak mining district is poorly described. The location shown in Attachment D is only approximate. The only record in the USGS minerals database (Wilson, 2003, MRDS D010667, MAS 80077001) places it in T. 34 N, R. 3 and 4 E (Henderson, 1926, p. 63) and information about the district in the citation (Colorado State Bureau of Mines [Colorado Division of Mines], 1898, p. 9-10) is sparse. In the course of the Chama-southern San Juan mineral resource assessment, several samples (T.34 N., R. 2 E., Sec. 9, SE 1/4) from unpatented claims at the head of White Creek, above Opal Lake, west of the Parcel boundary yielded no sign of "economically significant mineralization" (Lindquist, 1985, p. 139). No potential for locatable commodities was assigned to this area in the San Juan National Forest assessment. Mineral resource potential for all locatable commodities is low.

The Parcel is immediately adjacent to areas of permissive (low) potential for coal deposits (Van Loenen and Gibbons, 1997, p. 114, fig. 59). It is also in areas assessed as favorable for conventional oil and gas production in the Dakota sandstone play and fractured Mancos Shale play (Van Loenen and Gibbons, 1997, p. 121-127).

\section{REFERENCES:}

Brock, M.R., and Gaskill, D.L., 1985, Geology of the Chama-southern San Juan Mountains wilderness study area, Colorado, in U.S. Geological Survey and U.S. Bureau of Mines, Mineral Resources of the Chama-southern San Juan Mountains wilderness study area, Mineral, Rio Grande, Archuleta, and Conejos Counties, Colorado: U.S. Geological Survey Bulletin 1524, p. 5-34.

Colorado State Bureau of Mines [Colorado Division of Mines], 1898, Colorado-For the year 1897: Colorado State Bureau of Mines [Colorado Division of Mines] [Annual] Report, $167 \mathrm{p}$.

Henderson, C.W., 1926, Mining in Colorado: U.S. Geological Survey Professional Paper 138, $263 \mathrm{p}$.

Lindquist, A.E., 1985, Metallic and coal resources of the Chama-southern San Juan Mountains wilderness study area, Colorado, in U.S. Geological Survey and U.S. Bureau of Mines, Mineral Resources of the Chama-southern San Juan Mountains wilderness study area, Mineral, Rio Grande, Archuleta, and Conejos Counties, Colorado: U.S. Geological Survey Bulletin 1524, p. 123-152.

$: \backslash .$. locmin $\backslash$ locmin90.wpd 
Lipman, P.W., and Hail, W.J., Jr., 1975, Reconnaissance geologic map of the Chama Peak quadrangle, Conejos and Archuleta Counties, Colorado: U.S. Geological Survey Miscellaneous Field Studies Map MF-682, scale 1:48,000.

U.S. Geological Survey and U.S. Bureau of Mines, 1985, Mineral Resources of the Chamasouthern San Juan Mountains wilderness study area, Mineral, Rio Grande, Archuleta, and Conejos Counties, Colorado: U.S. Geological Survey Bulletin 1524, 152 p., 3 plates, scale $1: 48,000$.

Van Loenen, R.E., and Gibbons, A.B., 1997, Mineral Resource potential and geology of the San Juan National Forest, Colorado, with a section on Salable minerals, by A.G. Raby and J.S. Dersch, J.S.: U.S. Geological Survey Bulletin 2127, 140 p., 4 plates, scale $1: 250,000$.

Wilson, A.B., 2003, Databases and simplified geology for mineralized areas, claims, mines and prospects in Colorado: U.S. Geological Survey Open-File Report 03-090.

\section{$\underline{\text { LIST OF }} \underline{\text { ATTACHMENTS: }}$}

A. Exhibit A. Legal description of the location of Non-Federal mineral rights (on Federal lands, Parcel 1) considered in this mineral exchange (provided by USDA Forest Service).

B. Exhibit B. Legal description of the location Federal mineral rights (on Non-Federal lands, Parcel A) considered in this mineral exchange (provided by USDA Forest Service).

C. Report request (provided by USDA Forest Service).

D. Simplified geologic map showing approximate location of the mineral exchange properties (after Wilson, 2003, and unpublished data). 
Attachment A. Exhibit A. Legal description of the location of Non-Federal mineral rights (on Federal lands) considered in this mineral exchange (provided by USDA Forest Service).

\section{EXHIBIT A}

Property that the Non-Federal Party will consider exchanging:

\section{New Mexico Principal Meridian, Archuleta County, Colorado}

\section{Non-Federal Mineral Estate:}

Tract A of Exchange Survey No. 369 in the Tierra Amarilla Grant.

Containing 19,725.42 acres, more or less, of all oil, natural gas, coal and other minerals of any kind whatsoever, in under, or upon said lands, or any part thereof.

Land reservations of the Non-Federal Party and exceptions to title:

Reservations: None

Outstanding Rights: None 
Attachment B. Exhibit B. Legal description of the location of Federal mineral rights (on Non-Federal lands) considered in this mineral exchange (provided by USDA Forest Service).

\section{EXHIBIT B}

Property that the U.S.D.A. Forest Service will consider exchanging:

New Mexico Principal Meridian, Archuleta County, Colorado

Federal Oil and Gas Mineral Rights:

T. 33 N., R. 2 E.

Section 1: Lot 5, SW1/4NW1/4, W1/2SW1/4, SEl/4SW1/4;

Section 2: Lots $5,6,7,8,9,10,11,12,13,14,15,16,17,18,19,20$;

Section 3: Lots 1, 2, 3, 4, 5, 6, 7, SW1/4NE1/4, S1/2NW1/4, W1/2SEl/4, SW1/4;

Section 4: Lots 1, 3, 4, 5, 6;

Section 9: Lots 4, 5, 8;

Section 10: Lots $1,2,3,4,5,6,7,8$, E1/2;

Section 11: All;

Section 12: Lots 1, 2, 3, 4, SW1/4NE1/4, W1/2;

Section 13: Lots 1, 2, NW1/4;

Section 14: All;

Section 15: Lots 1, 2, 3, 4, 5, 6, 7, 8, E1/2;

Section 22: NE1/4NE1/4;

Section 23: N1/2, SE1/4, NE1/4SW1/4;

Section 24: Lots 4, 5;

Section 25: Lots 1, 2, 3, 4, W1/2NW1/4;

Section 26: E1/2E1/2; and

Tract B, Exchange Survey No. 369, in the Tierra Amarilla Grant.

Excepting and excluding the following lands previously patented:

T. 34 N., R. 2 E.

Section 24: Lot 1, SW1/4SE1/4, SE1/4SW1/4;

Section 25: Lots 1, 2, 3, 4, 5, E1/2NW1/4, SW1/4; and

Saratoga lode mining claim Nos. 6 and 7, Mineral Survey No. 12554; Mammoth lode mining claim Nos. 1, 2, 3, 4, 5, 6 and 7, Mineral Survey No. 12562; and Treasury lode mining claim

Nos. 1 and 2, Mineral Survey No. 12553, all in Banded Peak Mining District.

Containing 16,176.24 acres, more or less, of oil and gas rights.

Land reservations of the U.S.D.A. Forest Service, exceptions to title and uses to be recognized:

Reservations: None

Outstanding Rights: Valid existing rights held by third parties. 


\section{Attachment C. Report Request (provided by USDA Forest Service).}

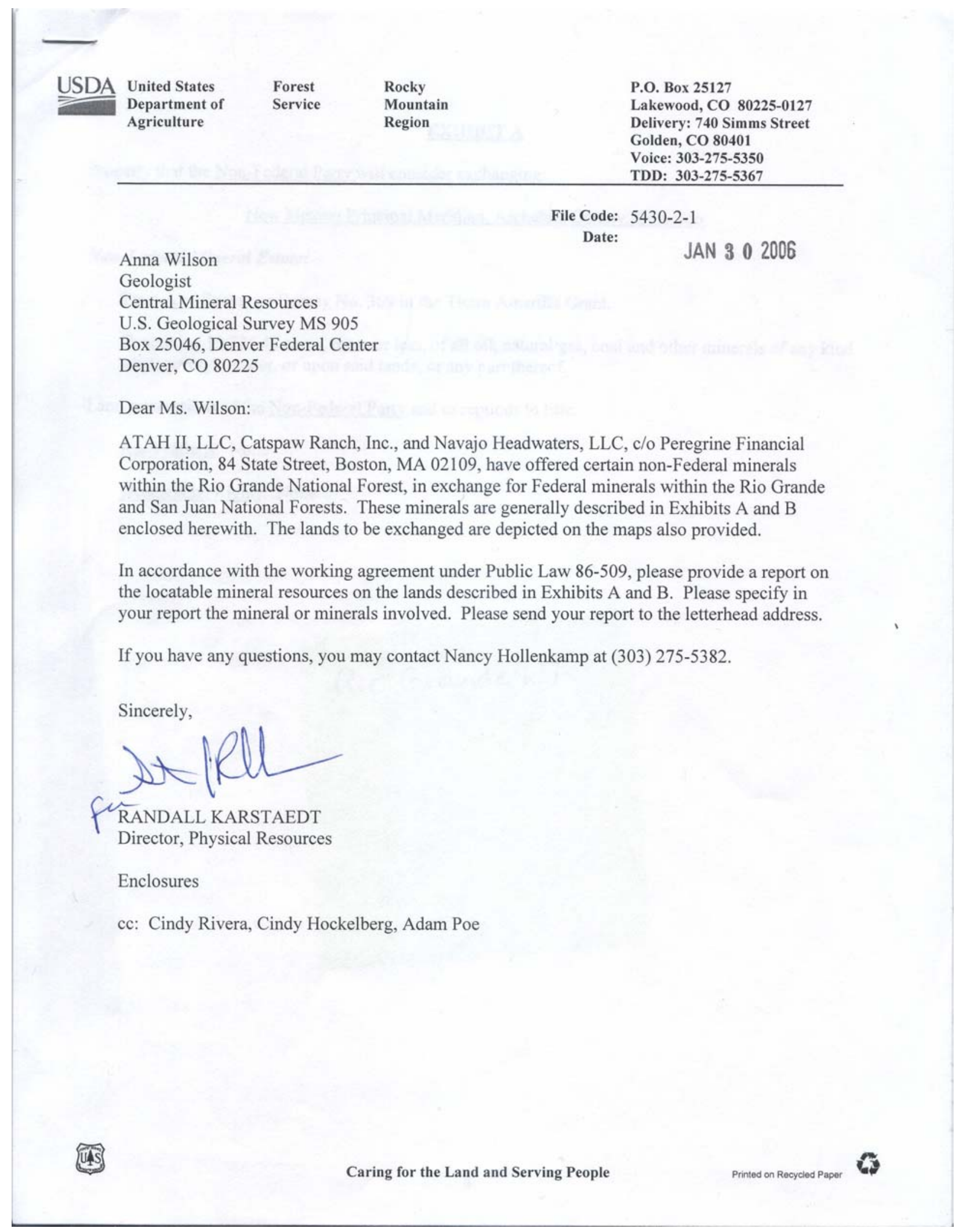


Attachment D. Simplified geologic map showing approximate location of the mineral exchange properties (after Wilson, 2003, and unpublished data).

Cretaceous sedimentary rocks (Ks, green); Tertiary sedimentary rocks (Ts, tan); Tertiary volcanics (Tv, orange); Tertiary volcaniclastics (Tvc, pink); Quaternary landslides, alluvium, colluvium, and moraines (Q, yellow).

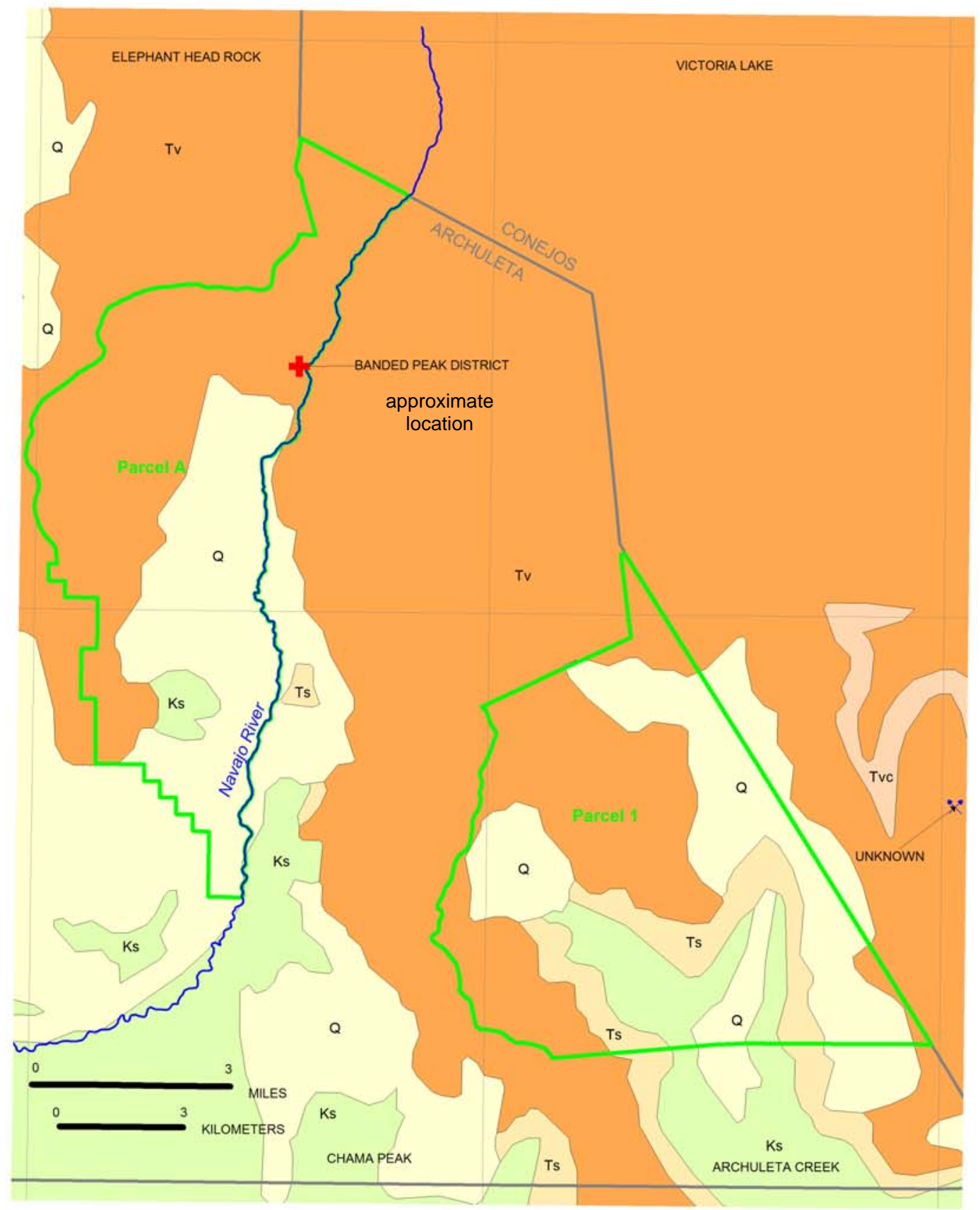




\title{
LOCATABLE MINERAL REPORT FOR THE \\ SNAKE RIVER LAND EXCHANGE OFFER, WHITE RIVER NATIONAL FOREST, SUMMIT COUNTY, COLORADO
}

\author{
By \\ Anna B. Wilson \\ U.S. Geological Survey \\ Administrative Report \\ March 11, 2008
}

The following report is based on information contained in USGS mineral resource and commodity files, mineral information databases (MRDS and MAS), and on reports and maps available in the USGS library. These data are occasionally augmented with unpublished documents, personal communications, and professional experiences. No field studies or onsite visits were performed in preparing this report. Emphasis is primarily on locatable mineral resources. Leasable and salable resources are covered only if they appear in the above documents. Mineral resource assessments are subjective: the opinions expressed herein are entirely those of the author. This report has not been reviewed for stratigraphic nomenclature. 


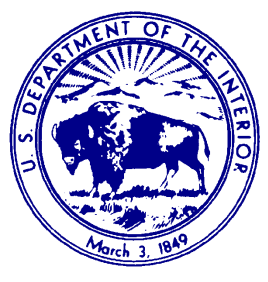

U.S. Department of the Interior

U.S. Geological Survey

Box 25046, MS 973

Denver Federal Center

Denver CO, 80225

March 11, 2008

Mr. Randall Karstaedt

Director, Physical Resources

U.S. Forest Service

P.O. Box 25127

Lakewood, CO 80225-0127

Dear Mr. Karstaedt:

This report is in response to your December 18, 2007 request (received 1/7/08) for information on locatable mineral resources in a land exchange proposal in which Chihuahua, LLC has offered certain non-Federal lands within the White River National Forest in exchange for Federal lands also within the White River National Forest.

In accordance with our long-term working agreement under Public Law 86-509, we are providing you with a report on the locatable mineral resources on the lands described in Exhibits $\mathrm{A}$ and $\mathrm{B}$, which were included with your request. These lands comprise approximately 116.61 acres in Summit County, Colorado.

Sincerely yours,

Anna B. Wilson, Geologist

Mineral Resources Program, Central Region

(303) 236-5593

awilson@usgs.gov

Copies: C.J. Nutt

N. Hollenkamp

M. Dunn

J.L. Freeman

P. Semmer 
For the legal location description of lands considered for exchange (exclusive of Reservations, Outstanding Rights, or other restrictions), refer to Exhibits A and B in Attachment A. The report request is Attachment $B$. Attachment $C$ is a geologic map (after Lovering, 1935b) showing the approximate boundary of the Non-Federal parcel. Attachment D is a geologic map (after Widmann and others, 2003) showing the approximate boundary of Federal Parcel 1, Dercum Dash. Attachment E is a geologic map (after Wallace and others, 2003) showing the approximate boundary of Federal Parcels 1 and 3, Claimjumper, and Cucumber Gulch.

\section{Non-Federal Lands}

Chihuahua Townsite

Montezuma 1:24,000, Denver West 1:100,000, Denver 1:250,000 quadrangles.

Chihuahua Townsite is located along Peru Creek at Chihuahua Gulch (Attachment C). Geologic mapping at 1:62,500 (Lovering, 1935b) shows this area is entirely underlain by Tertiary quartz monzonite (Tqm) of the Montezuma stock. Locally the monzonite is overlain by Pleistocene glacial till (Qgt) and Holocene (Recent) alluvium (Qal).

Chihuahua townsite is in the Montezuma mining district. It is currently considered to be part of the Argentine mineralized area (Attachment C), but the Argentine and Montezuma mineralized areas are so similar that the two areas may be merged into one (Wilson, 2003, and unpublished data). The Maid of Orleans mine is less than $1 / 2$ mi west of the townsite on the north side of Peru Creek. The Jumbo mine is almost due south of the Maid of Orleans on the south side of the creek.

When Lovering visited the Maid of Orleans site in 1929 (Lovering, 1935b, p. 86-87), the shaft (supposedly at $10,300 \mathrm{ft}$, but the location on modern topographic maps is uncertain) through which the ore was mined was full of water. The ore was along veins, probably 6-8 inches wide, containing galena, copper pyrites, and sulphurets" (Lovering, 1935b, p. 87). The only recorded production was 35 tons in 1885, approximately 2 tons in 1887, and 13 tons in 1888. At the time of mining, the 50 tons of silver ore was worth about $\$ 60$ per ton (Lovering, 1935b, p. 87). No mining is known to have occurred since.

The Jumbo mine produced about 100 tons of lead ore in 1888 and about 25 tons in 1900 (Lovering, 1935b, p. 85). The property was worked in 1914, 1915, 1916, and 1918 in conjunction with nearby mines, and collectively almost 6,800 tons of ore was produced and milled. Most of this production is assumed to be from the Jumbo. Ore occurred in quartz veins 6 inches to 1 foot wide and contained sphalerite, galena, and minor tetrahedrite and chalcopyrite.

Chihuahua Townsite is included in a tract assigned high potential for medium sized (10,000 200,000 short tons) polymetallic veins carrying silver, gold, copper, lead, and zinc (F14 of Toth and others, 1993). Toth and others did not outline any locatable industrial or leasable minerals in this area. 


\section{Federal Lands}

$\underline{\text { Parcel 1--Dercum Dash }}$

Keystone 1:24,000, Denver West 1:100,000, Denver 1:250,000 quadrangles.

Most of this parcel, at the base of Keystone ski area, is in early to late Pleistocene landslide deposits (Q1s), locally covered with Pleistocene to Holocene debris-fan deposits (Qf) (Widmann and others, 2003).

The Pilot mine, about $1 / 2 \mathrm{mi}$ to the east, was an intermittent lead-silver producer in the late $1800 \mathrm{~s}$. Claims in Jones Gulch (possibly on the east side of the gulch) may have been for gold (Wilson, 2003, CO_MAS record no. 81170093), though it is more likely that they were primarily leadsilver prospects (A. Wilson, 2008, U.S. Geological Survey, unpublished data).

At a mineral resource assessment scale of 1:250,000, Dercum Dash is included in a tract assigned high potential for medium-sized (10,000-200,000 short tons) polymetallic veins carrying silver, gold, copper, lead, and zinc (F14 of Toth and others, 1993). Toth and others did not outline any locatable industrial or leasable minerals in this area.

Parcel 2--Claimjumper

Breckenridge 1:24,000, Leadville 1:100,000, Leadville 1:250,000 quadrangles.

Geology in the vicinity of the parcel and Shock Hill is complex (Wallace and others, 2003). Faulted Jurassic to Cretaceous sedimentary bedrock including Early Cretaceous Dakota Sandstone $(\mathrm{Kd})$ and Late Jurassic Morrison Formation ( Jm) is mostly concealed by overlying early Pleistocene and late Pliocene Gravel of Gold Run (QTgg); Holocene and late Pleistocene fan deposits (Qf), colluvium (Qc), outwash deposits (Qop); and Holocene to middle Pleistocene landslide deposits (Q1s). Locally, there are small intrusive bodies of Eocene, megacrystic, quartz monzonite porphyry (Tqpm) (Wallace and others, 2003).

Iron Mask mine, Brooks-Snider, and Finding Shaft are either on or very close to the parcel. Little is known about the Iron Mask mine (Singewald, 1951, p. 70), an ore body above and below a sheet of porphyry (Ransome, 1911, p. 161). The Iron Mask shipped an unknown quanitity of high-grade silver-lead ore for about 10 years beginning in 1888 (Ransome, 1911, p. 18; Singewald, 1951, p. 70). By 1909 no sign of the ore body remained. The mineralogy of the ore is unknown, although it may have been largely carbonate ore containing free-sulphur (Ransome, 1911, p. 161; Singewald, 1951, p. 70). In 1901, oxidized shipping ore contained 0.03 oz/ton gold, $21 \mathrm{oz} /$ ton silver, 58 percent lead, 3 percent iron, and 9 percent silica (Lovering and Goddard, 1950, p. 105).

Brooks-Snider mine was a "honeycomb" of workings on the northwest side of Shock Hill (Singewald, 1951, p. 70). In 1898, concentrates contained 1.3 oz/ton gold, 3 oz/ton silver, 3 
percent iron, and 71 percent silica (Lovering and Goddard, 1950, p. 105). The ore was in small pockets in irregular fractures in the Dakota Sandstone (quartzite) (Singewald, 1951, p. 70, 72).

Finding Shaft, at the top of Shock Hill, contained pyrite and sphalerite, although it does not appear that it was mined (Ransome, 1911, p. 161).

The parcel is within an area that was assessed (at a scale of 1:250,000) as having high resource potential for silver, gold, copper, lead, and zinc in small $(<250,000$ short tons) replacement deposits, based on the presence of the following: Dakota Sandstone, plutonic bodies, extensive faults, anomalous trace metal values, and proximity to a known mining district (Toth and others, 1993, p. 59, tract D6). The parcel also is within an area having high resource potential for large ( $>200,000$ short tons) deposits of those same base and precious metals in veins (Toth and others, 1993, p. 67, Tract F13). Potential for medium-sized (22,000-1,100,000 short tons) placer gold deposits is also high along the Blue River and its tributaries in the Breckenridge area (Toth and others, 1993, p. 76-79, Tract K7).

Parcel 3--Cucumber Gulch

Breckenridge 1:24,000, Leadville 1:100,000, Leadville 1:250,000 quadrangles.

Geology of the Cucumber Gulch parcel is mapped entirely as early Pleistocene and late Pliocene Gravel of Gold Run (QTgg) (Wallace and others, 2003).

At 1:250,000 scale, the parcel would appear to have the same resource potential as the Claimjumper, Parcel 2 (see above) if the bedrock is not too deeply buried by the gravels.

\section{LIST OF ATTACHMENTS:}

A. Exhibit A. Legal description of land considered in this exchange (provided by the USDA Forest Service) exclusive of reservations and outstanding rights.

B. Report request (provided by the USDA Forest Service).

C. Geologic map showing the approximate boundary of the non-Federal parcel, Chihuahua Townsite (after Lovering, 1935b).

D. Geologic map showing the approximate boundary of Federal parcel 1, Dercum Dash (after Widmann and others, 2003).

E. Geologic map showing the approximate boundary of Federal parcels 2 and 3:

Claimjumper and Cucumber Gulch (after Wallace and others, 2003). 


\section{REFERENCES:}

Lovering, T.S., 1935a, Geology and ore deposits of the Breckenridge mining district, Colorado: U.S. Geological Survey Professional Paper 176, 64 p.

Lovering, T.S., 1935b, Geology and ore deposits of the Montezuma quadrangle, Colorado: U.S. Geological Survey Professional Paper 178, 119 p.

Lovering, T.S., and Goddard, E.N., 1950, Geology and ore deposits of the Front Range, Colorado: U.S. Geological Survey Professional Paper 223, 319 p.

Ransome, F.L., 1911, Geology and ore deposits of the Breckenridge district, Colorado: U.S. Geological Survey Professional Paper 75, 184 p.

Singewald, Q.D., 1951, Geology and ore deposits of the Upper Blue River area, Summit County, Colorado: U.S. Geological Survey Bulletin 970, 74 p.

Toth, M.I., Wilson, A.B., Cookro, T.M., Bankey, Viki, Lee, G.K., and Case, J.E., 1993, Mineral resource potential and geology of the White River National Forest and the Dillon Ranger District of the Arapaho National Forest, Colorado, with a section on Salable Commodities by J.S. Dersch: U.S. Geological Survey Bulletin 2035, 117 p.

Wallace, C.A., Keller, J.W., McCalpin, J.P., Bartos, P.J., Route, E.E., Jones, N.N., Gutierrez, F., Williams, C.L., and Morgan, M.L., 2003, Geologic map of the Breckenridge quadrangle, Summit and Park Counties, Colorado: Colorado Geological Survey Open-File Report $02-7$, scale 1:24,000, and 44-page pamphlet.

Widmann, B.L., Morgan, M.L., Bartos, P.J., Shaver, K.C., Gutierrez, F., and Lockman, A., 2003, Geologic map of the Keystone quadrangle, Summit County, Colorado: Colorado Geological Survey Open-File Report 02-3, scale 1:24,000, and 22 page pamphlet.

Wilson, A.B., 2003, Databases and simplified geology for mineralized areas, claims, mines and prospects in Colorado: U.S. Geological Survey Open-File Report 2003-90. [http://pubs.usgs.gov/of/2003/ofr-03-090/] 


\section{Attachment A. Exhibits A and B-Legal description of lands considered in this exchange exclusive of reservations, outstanding rights, or other interests (provided by the USDA Forest Service).}

\section{EXHIBIT A}

Property that the Non-Federal Party will consider exchanging:

$\underline{\text { Sixth Principal Meridian, Summit County, Colorado }}$

Chihuahua Townsite

The Foster Millsite (M.S. No. 954) according to Mineral Entry Patent Number 17650, recorded in Book 285 at Page 820, The Chihuahua Placer (M.S. No. 952) according to Mineral Entry Patent Number 4361, recorded in Book 23 at Page 519; The Aldrich Millsite (M.S. No. 951) according to Mineral Entry Patent Number 4785, recorded in Book 285 at Page 815, The Fifth of July Millsite (M.S. No. 1069B) according to Mineral Entry Patent Number 5530, recorded in Book 242 at Page 380, and The Ruby Silver Millsite (M.S. No. 960B) according to Mineral Entry Patent Number 101285, recorded at Reception No. 501348 and all located in Section 24, Township 5 South, Range 76 West and Section 19, Township 5 South, Range 75 West of the Sixth Principal Meridian, Summit County, Colorado.

Totaling 42.78 acres.

\section{$\underline{\text { EXHIBIT B }}$}

Property that the U.S.D.A. Forest Service will consider exchanging:

\section{$\underline{\text { Sixth Principal Meridian, Summit County, Colorado }}$}

1. Dercum Dash

\section{T. 6 S., R. 76 W.} sec. 19: lots 34 and 35 and the N1/2 SW1/4 SW1/4 NE1/4;

2. Claimjumper

T. 6 S., R. 77 W., sec. 30 : lots 45 and 46 ; sec. 31: lot 27;

T. 6 S., R. 78 W., sec. 25: lots 8,17 and 18 ; sec. 36: lot 10;

3. Cucumber Gulch Wedge

$$
\text { T. } 6 \text { S., R. } 78 \text { W., }
$$
sec. 36: lots 36,37 and 38 .

All totaling 73.83 acres, more or less. 


\section{Attachment B. Report Request (provided by the USDA Forest Service).}

\begin{tabular}{llll} 
USDA United States \\
$\begin{array}{l}\text { Department of } \\
\text { Agriculture }\end{array}$ & $\begin{array}{l}\text { Forest } \\
\text { Service }\end{array}$ & $\begin{array}{l}\text { Rocky } \\
\text { Mountain } \\
\text { Region }\end{array}$ & $\begin{array}{l}740 \text { Simms Street } \\
\text { Golden, CO 80401 } \\
\text { Voice: } 303-275-5350 \\
\text { TDD: } 303-275-5367\end{array}$ \\
\hline
\end{tabular}

Anna Wilson

File Code: $5430-2-1$

Date: DEC 182007

Geologist

U.S. Geological Survey

Central Mineral Resources MS 905

Box 25046

Denver, CO 80225

Dear Ms. Wilson:

Chihuahua, LLC, of P.O. Box 1884, 56 River Run Road \#204, Dillon, Colorado and the Town of Breckenridge, P.O. Box 168, Breckenridge, Colorado, acting by and through Western Land Group, Inc., their agent (Snake River exchange), have offered certain non-Federal lands within the White River National Forest, in exchange for Federal lands also within the White River National Forest. These lands are generally described in Exhibits A and B enclosed herewith. The lands to be exchanged are depicted on the maps also provided.

In accordance with the working agreement under Public Law 86-509, please provide a report on the locatable mineral resources on the lands described in Exhibits A and B. Please specify in your report the mineral or minerals involved. Please send your report to the letterhead address.

If you have any questions, you may contact Nancy Hollenkamp at (303) 275-5382.

Sincerely,

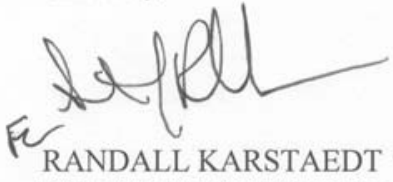

Director, Physical Resources

Enclosures

cc: Jonathan L Freeman, Paul Semmer 


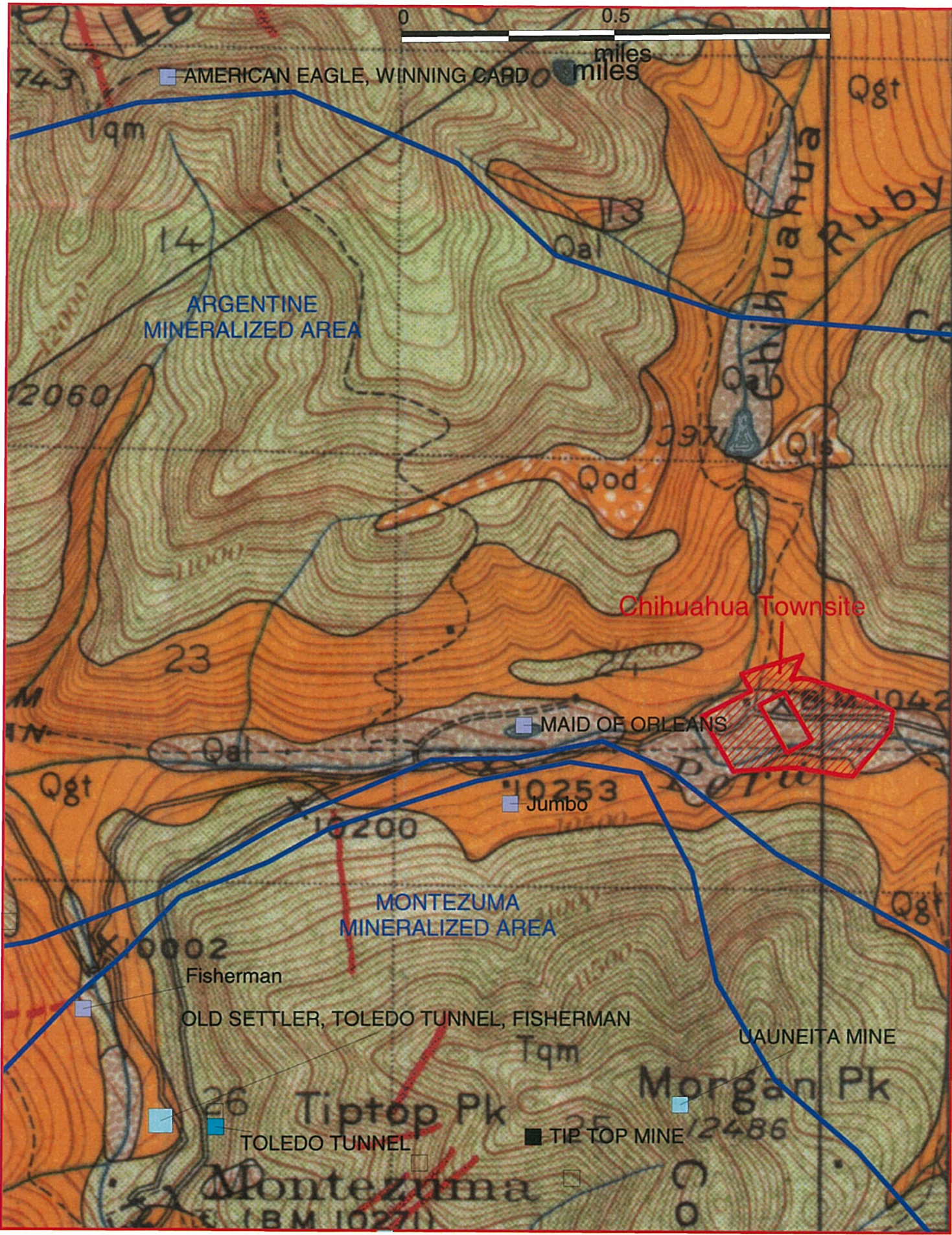

Attachment C. Geologic map showing the approximate boundary of the Non-Federal parcel, Chihuahua Townsite (after Lovering, 1935b). Tqm (green), Tertiary quartz monzonite; Qgt (mustard), Quaternary glacial till; Qal (tan specks), Quaternary alluvium. Mines (squares) from Wilson (2003, and unpublished data). Approximate scale 1:24,000. 


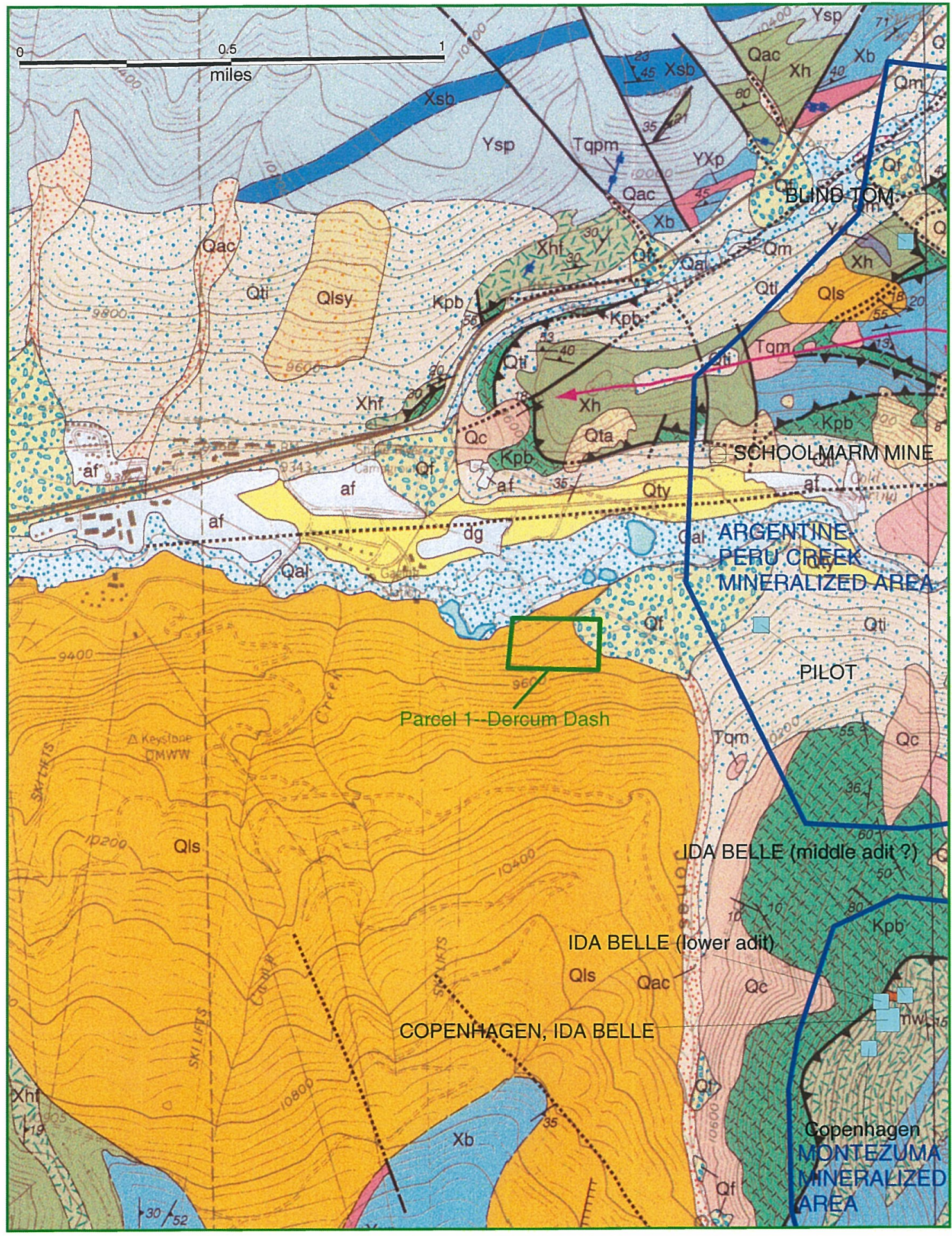

$39^{\circ} 37^{\prime} 30^{\prime \prime}$

Attachment D. Geologic map showing the approximate boundary of Federal parcel 1, Dercum Dash (after Widmann and others, 2003). Qls (mustard), Pleistocene landslide; Qf (yellow with blue specks), Holocene to Pleistocene debris-fan deposits. Mine information from Wilson (2003, and unpublished data). Approximate scale 1:24,000. 


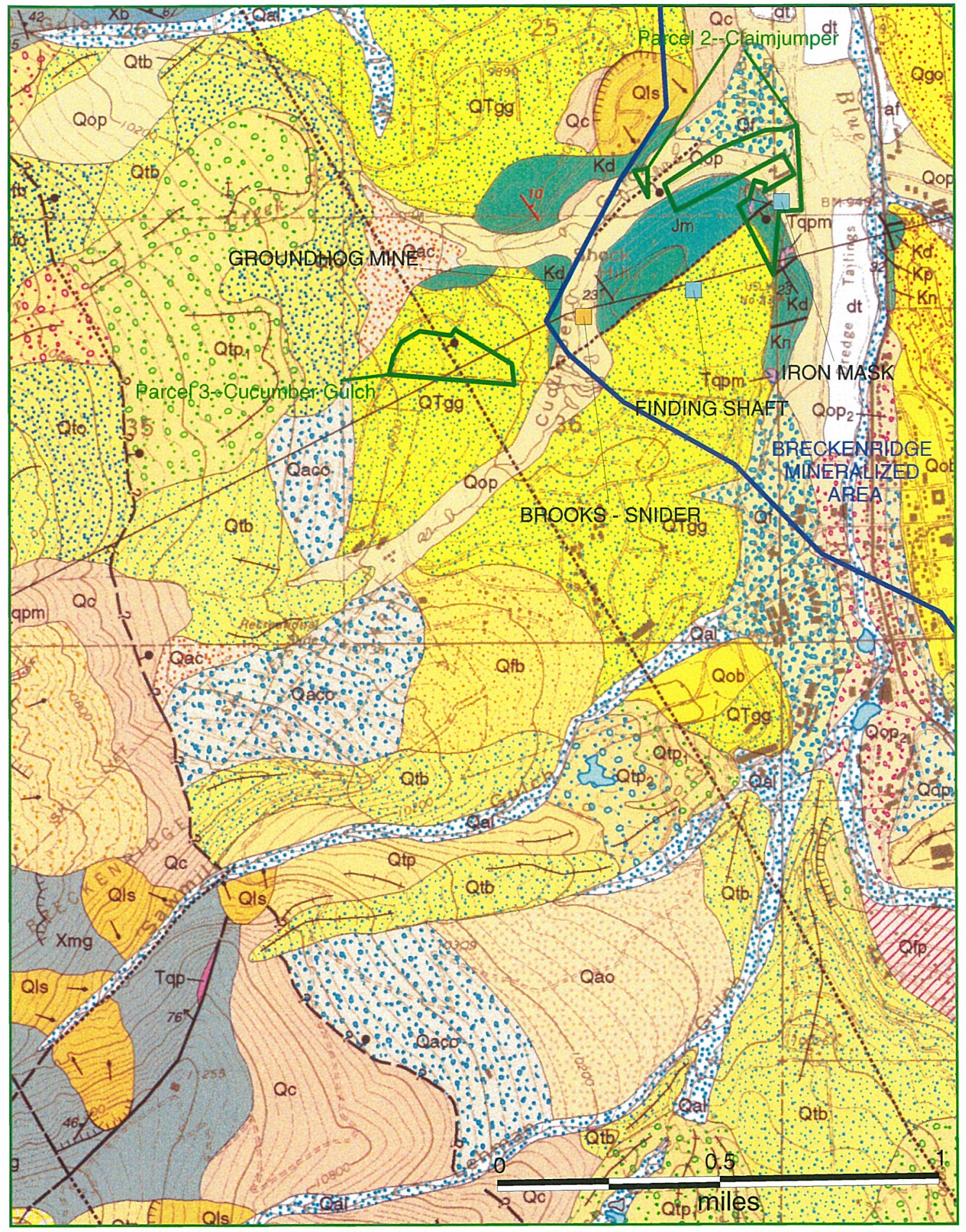

Attachment E. Geologic map showing the approximate boundary of Federal parcels 1 and 2, Claimjumper and Cucumber Gulch (after Wallace and others, 2003). Map units include Early Cretaceous Dakota Sandstone (Kd), Late Jurassic Morrison Fomration (Jm), early Pleistocene and late Pliocene Gravel of Gold Run (QTgg), Holocene and late Pleistocene fan deposits (Qf), colluvium (Qc), and outwash deposits (Qop); and Holocene to middle Pleistocene landslide deposits. Mine information from Wilson (2003, and unpublished data). Approximate scale 1:24,000. 
SOUTH DAKOTA 


\section{LOCATABLE MINERAL REPORT FOR THE GREYHOUND LAND EXCHANGE OFFER, BLACK HILLS NATIONAL FOREST, PENNINGTON COUNTY, SOUTH DAKOTA}

By

Anna B. Wilson

U.S. Geological Survey

Administrative Report

August 21, 2006

The following report is based on information contained in USGS mineral resource and commodity files, in mineral information databases (MRDS and MAS), and on reports and maps available in the USGS library. These data are occasionally augmented with unpublished documents, personal communications, and professional experiences. No field studies or on-site visits were performed in preparing this report. Emphasis is primarily on locatable mineral resources. Leasable and salable resources are covered only if they appear in the above documents. Mineral resource assessments are subjective: the opinions expressed herein are entirely those of the author. This report has not been reviewed for stratigraphic nomenclature. Any use of trade, product, or firm names is for descriptive purposes and does not imply endorsement by the U.S. Government. 


\title{
U.S. Department of the Interior
}

\author{
U.S. Geological Survey \\ Box 25046, MS 905 \\ Denver Federal Center \\ Denver CO, 80225
}

June 1, 2006

Mr. Randall Karstaedt

Director, Physical Resources

U.S.D.A. Forest Service

P.O. Box 25127

Lakewood, CO 80225-0127

Dear Mr. Karstaedt:

This report is in response to your May 3 (received May 30) request for information on locatable mineral resources in a land exchange proposal in which Capstone, LLC has offered certain nonFederal minerals within the Black Hills National Forest, in exchange for Federal minerals also within the Black Hills National Forest.

In accordance with our long-term working agreement under Public Law 86-509, we are providing you with a report on the locatable mineral resources on the lands described in Exhibits A and B, which were included with your request. These lands comprise approximately 247 acres in Pennington County, South Dakota.

Sincerely yours,

Anna B. Wilson, Geologist

Mineral Resources Program, Central Region

Copies: $\quad$ C.J. Nutt

R. Baer

N. Hollenkamp 
For the legal location description of lands considered for exchange, refer to Exhibits A and B in Attachments A and B. The report request is Attachment C. Attachment D is a geologic map showing the approximate location of the Non-federal Norbeck parcel.

\section{$\underline{\text { Non-Federal }}$}

Norbeck

Mt. Rushmore, Iron Mountain 1:24,000; Mount Rushmore 1:100,000; Hot Springs 1:250,000 quadrangles.

The Norbeck parcel is underlain by Proterozoic quartz mica schist, quartz schist, and quartzmica-staurolite schist (map unit qm of Norton, 1976; Attachment D). There may be a very thin band of graphite schist in the southwestern corner of the tract.

Norbeck parcel is immediately south of the White Cap (King Mica, \#513 of Wilson and DeWitt, 1995) deposit and west of the Expectation (\#515 of Wilson and DeWitt, 1995) deposit. Both are Early Proterozoic potassium-feldspar-rich pegmatites (type E of DeWitt and others, 1988b and Wilson and DeWitt, 1995). No deposits occur in the immediate vicinity of the southern part of the parcel (DeWitt and others, 1988c). The parcel is in the Hugo "district ${ }^{\text {at" }}$, a region delineated as having potential for Early Proterozoic potassium-feldspar pegmatite deposits (Wilson and DeWitt, 1995). Overlapping the Hugo "district" are 2 additional "districts", the Holy Terror (type D; Au, Ag Proterozoic vein deposits) and the Etta (Types G and J; Proterozoic pegmatites containing Be and Li).

Proximity to two potassium-feldspar pegmatite deposits occurring in the same general package of host rocks (Norton, 1976) suggests a high potential for feldspar-rich pegmatite deposits on the Norbeck parcel. There is also moderate potential for type D, Au-Ag Proterozoic vein deposits and Proterozoic pegmatites containing Be and Li (Wilson and DeWitt, 1995) as suggested by the overlapping Holy Terror and Etta "districts". Pegmatite deposits in the vicinity are not currently being mined for feldspar, suggesting that any such deposits are sub-economic.

\section{$\underline{\text { Federal }}$}

Parcel 1: Pink Cabin

Hill City 1:24,000; Mount Rushmore 1:100,000; Hot Springs 1:250,000 quadrangles.

Pink Cabin parcel is underlain by Bugtown Formation which is composed of quartz-mica, staurolite and sillimanite schists interlayered with thick-bedded quartz schist and metagraywacke (Ratte and Wayland, 1969; map unit bm on Attachment E). Immediately west of the parcel adjoining the Dolcode mine (identified as the Addie and Ida claims by DeWitt and others, 1988a), a subunit of the Bugtown formation containing mainly thin-bedded graphitic quartz schist and quartz-biotite-garnet schist, is exposed (Ratte and Wayland, 1969; map unit bb on Attachment E).

\footnotetext{
${ }^{a}$ District is used here to mean a mineralized area containing similar types of mineral deposits. It does not refer to a geographic, historic, political, or administrative mineral district.
} 
On the mineral deposits map (DeWitt and others, 1988a), six named deposits are within about a mile of the parcel and many small unnamed prospects riddle the parcel between the Ida and Addie mines (labeled Dolcode mine on Hill City topographic map) and the Goodluck property (Attachment E). The Eldorado and Summit mines are in the thickbedded graywacke unit of the Bugtown Formation (unit bg, Attachment E). The Dolcode mine is in a graphictic quartz schist and quartz-biotite schist of the Bugtown Formation (unit bb; Attachment E). The Goodluck, Heart of the Black Hills, and February mines, all Early Proterozoic pegmatite-hosted tin-tungsten occurrences containing cassiterite and sulfides are in the metagraywacke unit of the Bugtown Formation (unit bm, Attachment E) (DeWitt and others, 1988a; Ratte and Wayland, 1969). The Hill City "district", which includes the Pink Cabin parcel, is overlapped by the Three Forks gold vein "district" (Wilson and Dewitt, 1995). Based on proximity to known deposits and the multitude of prospects on this property, mineral resource potential for tin and tungsten in pegmatite is high. The metagraywacke unit (unit bg of Ratte and Wayland, 1969; Attachment E) of the Bugtown Formation that hosts gold deposits such as the Summit and Eldorado mines is not present in the parcel. Therefore, mineral potential for gold on the Pink Cabin parcel is low.

\section{Parcel 2: Boulder Hill}

Mt. Rushmore 1:24,000; Mount Rushmore 1:100,000; Hot Springs 1:250,000 quadrangles.

Geologically, the Boulder Hill parcel is probably in the same quartz-mica schist, quartz schist, and quartz-mica-staurolite schist as the Norbeck parcel (Norton, 1976; Attachment F), but this is not certain as the parcel appears to be at the margin of the mapped area and may or not be included in it. No other detailed geologic maps of this area are available.

Boulder Hill parcel is about a mile east of the Calumet "district" which contains Early Proterozoic gold-silver syngenetic stratiform and gold-silver vein deposits (Wilson and DeWitt, 1995). No mines, claims, or prospects are known on the parcel (DeWitt and others, 1988b). Based on proximity to a known mining district containing similar host rocks, mineral resource potential would be moderate, but the lack of prospects in this otherwise heavily prospected area reduces the potential to low.

\section{LIST OF ATTACHMENTS:}

A. Exhibit A. Legal description of the Non-Federal (Norbeck) parcel considered in this land exchange (provided by USDA Forest Service).

B. Exhibit B. Legal description of the Federal (Boulder Hill and Pink Cabin) parcel considered in this land exchange (provided by USDA Forest Service).

C. $\quad$ Report request (provided by USDA Forest Service).

D. Approximate location of the Norbeck parcel and adjacent mines, claims or prospects (from DeWitt and others, 1988b) shown with the geology (after Norton, 1976).

E. Approximate location of the Pink Cabin parcel and adjacent mines, claims or prospects (from DeWitt and others, 1988a; Ratte and Wayland, 1969) shown with the geology (after Ratte and Wayland, 1969).

F. Geologic map showing the approximate location of the Boulder Hill parcel (after Norton, 1976). 


\section{$\underline{\text { REFERENCES: }}$}

DeWitt, Ed; Buscher, David; Wilson, Anna Burack; and Johnson, Tom, 1988a, Map showing locations of mines, prospects, and patented mining claims, and classification of mineral deposits in the Hill City 7 1/2-minute quadrangle, Black Hills, South Dakota: U.S. Geological Survey Miscellaneous Field Studies Map MF-1978-J, scale 1:24,000.

DeWitt, Ed; Buscher, David; Wilson, Anna Burack; and Johnson, Tom, 1988b, Map showing locations of mines, prospects, and patented mining claims, and classification of mineral deposits in the Mount Rushmore 7 1/2-minute quadrangle, Black Hills, South Dakota: U.S. Geological Survey Miscellaneous Field Studies Map MF-1978-K, scale 1:24,000.

DeWitt, Ed; Buscher, David; Wilson, Anna Burack; and Johnson, Tom, 1988c, Map showing locations of mines, prospects, and patented mining claims, and classification of mineral deposits in parts of the Iron Mountain and Hayward 7 1/2-minute quadrangles, Black Hills, South Dakota: U.S. Geological Survey Miscellaneous Field Studies Map MF1978-N, scale 1:24,000.

Norton, J.J., 1976, Field compilation map of the geology of the Keystone area, Black Hills, South Dakota: U.S. Geological Survey Open-File Report 76-297, scale 1:24,000.

Ratte, J.C., and Wayland, R.G., 1969, Geology of the Hill City quadrangle, Pennington County, South Dakota-A preliminary report: U.S. Geological Survey Bulletin 1271-B, 14 p., map scale 1:24,000.

Wilson, Anna B., and DeWitt, Ed, 1995, Map showing metallic mineral districts and mines in the Black Hills, South Dakota and Wyoming: U.S. Geological Survey Miscellaneous Investigations Series Map I-2445, scale 1:100,000. 
Attachment A. Exhibit A. Legal description of the location of Non-Federal mineral rights (on Federal lands) considered in this mineral exchange (provided by USDA Forest Service).

\section{EXHIBIT A}

Property that the Non-Federal Party will consider exchanging:

\section{Black Hills Meridian, Pennington County, South Dakota}

Township 2 South, Range 6 East, Section 16, W1/2SE1/4 and SW1/4NE1/4

Containing 120 acres, more or less.

As may be necessary to achieve an equal value land exchange, as determined by appraisals reviewed and approved by the Forest Service, the non-Federal party agrees to either reduce the size of the Federal parcel and/or convey additional non-Federal lands to the United States.

If it is deemed necessary and desirable to increase the size of the non-Federal parcel, the following non-Federal parcel shall be added to the exchange:

\section{Black Hills Meridian, Pennington County, South Dakota}

Township 2 South, Range 6 East, Section 16, SE1/4NW1/4

Containing 40 acres, more or less.

Land reservations of the Non-Federal Party and exceptions to title:

Reservations: None

Outstanding Rights:

1. Easement dated May 2, 1986, granted to the United States of America, filed September 3, 1986, and recorded in Book 29 of misc. records on page(s) 317 in the Office of the Register of Deeds, Pennington County, South Dakota.

2. Request to use section line along the NW1/4SW1/4, Section 16, T2S, R6E, BHM, filed March 13, 1995, and recorded in Book 58 of Misc. Records on Page(s) 364 in the Office of the Register of Deeds, Pennington County, South Dakota.

3. Access to and from the above-described real property is limited to the extent as disclosed by Easement recorded in Book 29 of Misc. Records on Page(s) 317 in the Office of the Register of Deeds, Pennington County, South Dakota.

4. Subject to statutory section line right-of-way. 
Attachment B. Exhibit B. Legal description of the location of Federal mineral rights (on Non-Federal lands) considered in this mineral exchange (provided by USDA Forest Service).

\section{EXHIBIT B}

Property that the U.S.D.A. Forest Service will consider exchanging:

\section{Black Hills Meridian, Pennington County, South Dakota}

Parcel 1:

Township 1 South, Range 5 East, Section 27, a portion of the W1/2SW1/4*;

Township 1 South, Range 5 East, Section 28, Lot 12

Containing 57.18 acres more or less.

Parcel 2:

Township 1 South, Range 6 East, Section 22, NW1/4SE1/4 less STA Tract 0012*

Containing 39.704 acres more or less.

Containing an aggregate of 96.884 acres, more or less.

*(Note: BLM survey(s) and/or Supplemental Plats will be necessary to properly describe these parcels prior to closing.)

Land reservations of the U.S.D.A. Forest Service, exceptions to title and uses to be recognized:

\section{Reservations:}

1. Reserving to the United States a right-of-way thereon for ditches or canals constructed by the authority of the United States Act of August 30, 1890 (26 Stat. 391; 43 U.S.C. 945). (Affects Parcels 1 \& 2)

Outstanding Rights:

1. Road right-of-way issued to Pennington County on 1-7-1982 for Pink Cabin FDR 353.1B, Book 17, Page 6827. (Affects Parcel 1)

2. Road easement issued 1-7-1982 for FDR 485, Book 17, Page 6882, $66 \mathrm{ft}$. in width, and .2 mile in length. (Affects Parcel 2)

Other:

1. Roadside zone withdrawal issued 10-24-1957 for U.S. Highways 16 and 16A, PLO 1535, BLM \#M-13790, 660-ft. width. This withdrawal requires revocation/ modification prior to closing of this transaction. (Affects Parcel 2) 


\section{Attachment C. Report Request (provided by USDA Forest Service).}

\begin{tabular}{llll} 
USDA United States & Forest & Rocky & P.O. Box 25127 \\
Department of & Service & Mountain & Lakewood, CO 80225-0127 \\
Agriculture & & Region & Delivery: 740 Simms Street \\
& & & Golden, CO 80401 \\
& & Voice: 303-275-5350 \\
& & & TDD: 303-275-5367 \\
\hline
\end{tabular}

File Code: $5430-2-1$

Date:

Anna Wilson

MAY 032006

Geologist

U.S. Geological Survey MS 905

Central Mineral Resources

Box 25046, Denver Federal Center

Denver, CO 80225

Dear Ms. Wilson:

Capstone, LLC, of 4813 Carriage Hills Drive, Rapid City, South Dakota 57702, has offered certain non-Federal lands within the Black Hills National Forest, in exchange for Federal lands also within the Black Hills National Forest. These lands are generally described in Exhibits A and $\mathrm{B}$ enclosed herewith. The lands to be exchanged are depicted on the maps also provided.

In accordance with the working agreement under Public Law 86-509, please provide a report on the locatable mineral resources on the lands described in Exhibits A and B. Please specify in your report the mineral or minerals involved. Please send your report to the letterhead address.

If you have any questions, you may contact Nancy Hollenkamp at (303) 275-5382.

Sincerely,

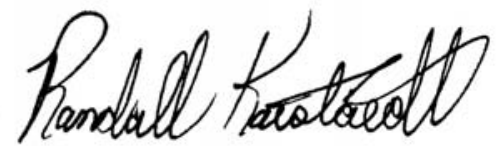

RANDALL KARSTAEDT

Director, Physical Resources

Enclosures

cc: Craig Kjar, Michael W Beale 
Attachment D. Approximate location of the Norbeck parcel and adjacent mines, claims or prospects (from DeWitt and others, 1988b) shown with the geology (after Norton, 1976).

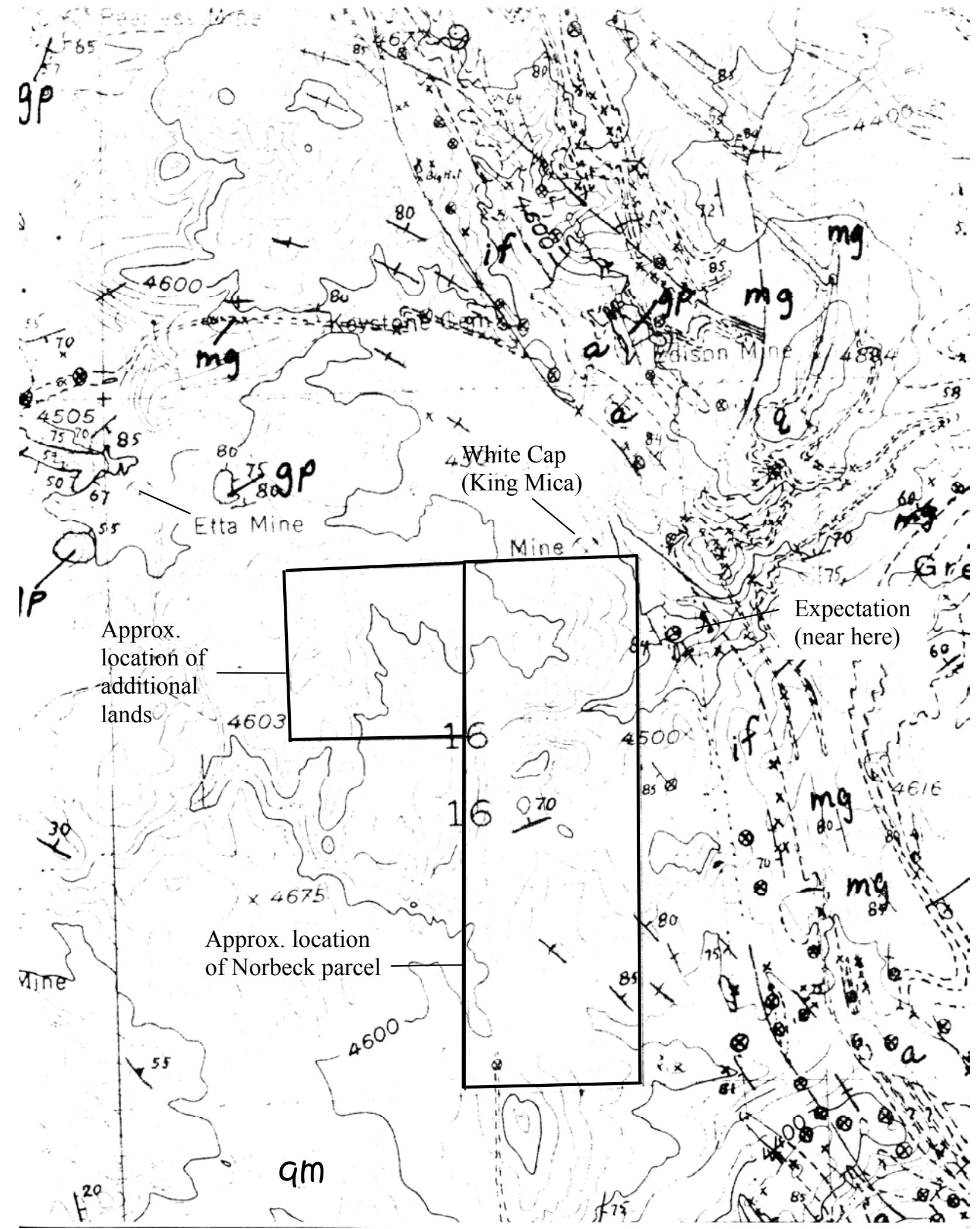

Scale approximately 1:12,000. qm, quartz-mica-staurolite schist; gp, granite and pegmatite; mg, mica-garnet schist, quartz-mica schist, and quartzite; if, grunerite schist and quartzite; a, amphibolite.. 
Attachment E. Approximate location of the Pink Cabin parcel and adjacent mines, claims or prospects (from DeWitt and others, 1988a; Ratte and Wayland, 1969) shown with the geology (after Ratte and Wayland, 1969). (Note that Canadaville is labeled Kennedyville on some maps)

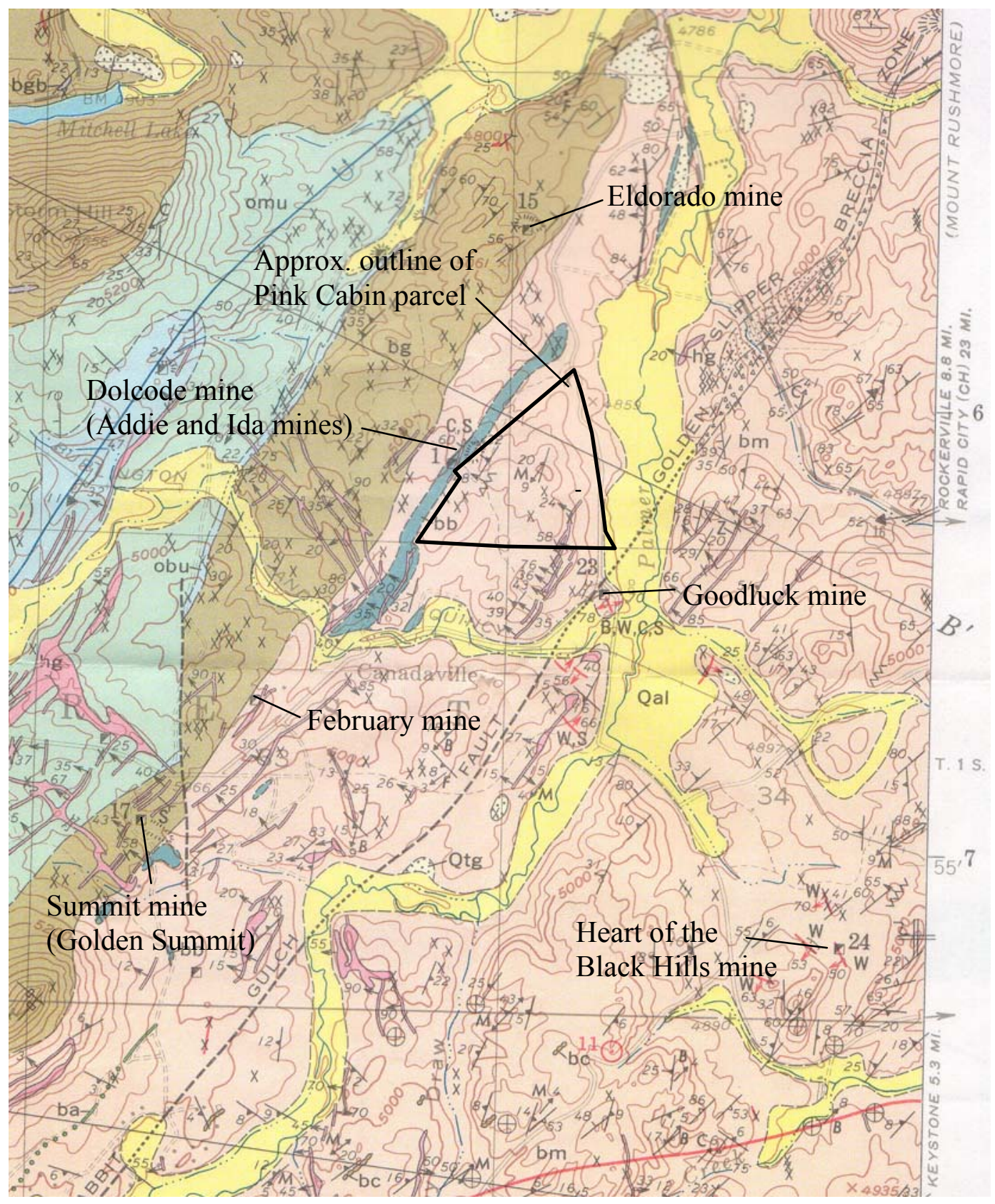

Scale approximately 1:24,000. bg, bm, bb, phases of the Bugtown Formation. omu and obu, muscovite and biotite facies of the upper Oreville Formation; Qal, Quaternary alluvium; hg, Harney Peak Granite. 
Attachment F. Geologic map showing the approximate location of the Boulder Hill parcel (after Norton, 1976).

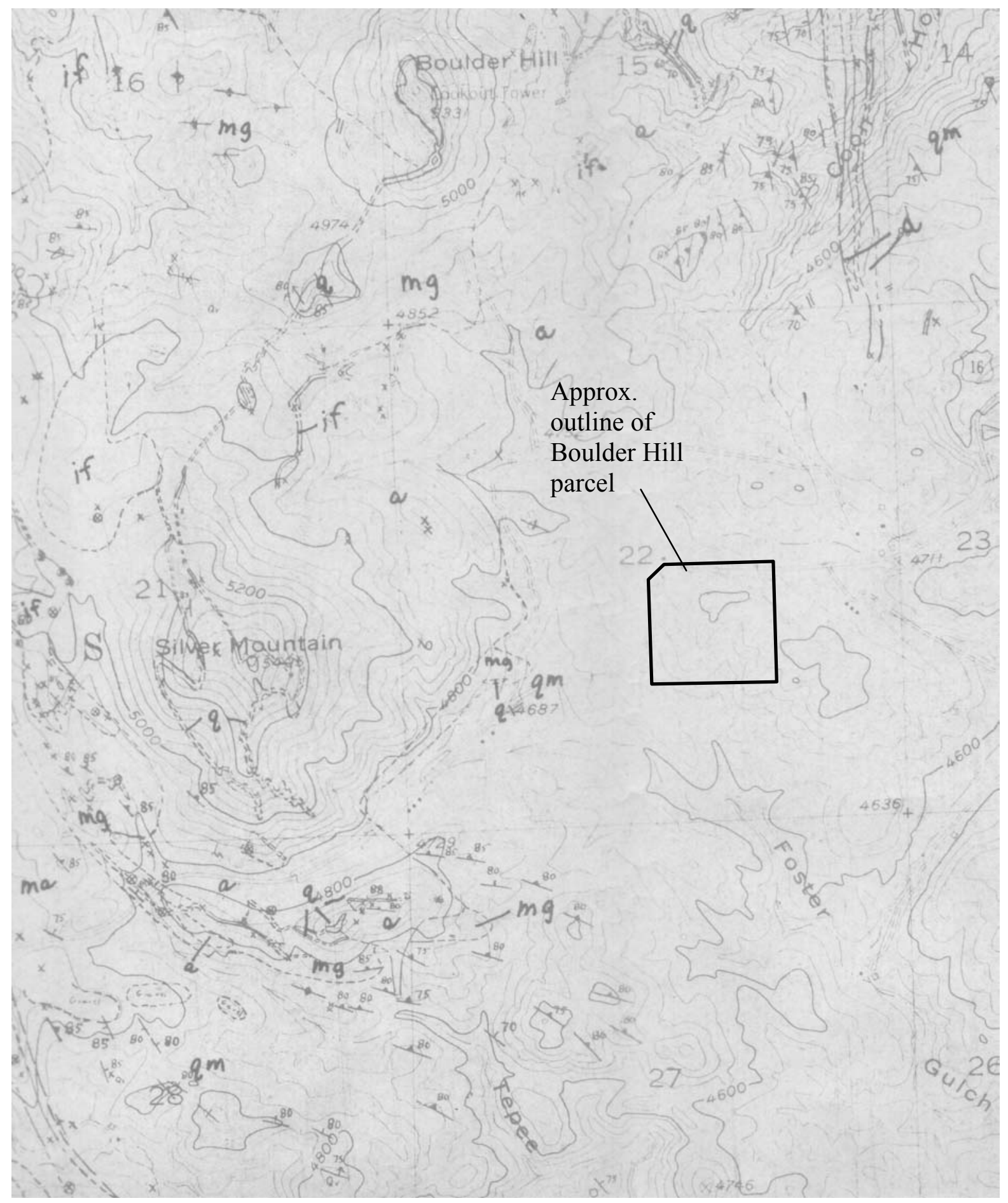

Scale approximately 1:24,000. qm, quartz-mica-staurolite schist; mg, mica-garnet schist, quartzmica schist, and quartzite; if, grunerite schist and quartzite; a, amphibolite; q, cherty quartzite. 


\section{LOCATABLE MINERAL REPORT FOR THE GRIZZLY LAND EXCHANGE OFFER, BLACK HILLS NATIONAL FOREST, PENNINGTON AND LAWRENCE COUNTIES, SOUTH DAKOTA}

By

Anna B. Wilson

U.S. Geological Survey

Administrative Report

October 16, 2007

The following report is based on information contained in USGS mineral resource and commodity files, in mineral information databases (MRDS and MAS), and on reports and maps available in the USGS library. These data are occasionally augmented with unpublished documents, personal communications, and professional experiences. No field studies or on-site visits were performed in preparing this report. Emphasis is primarily on locatable mineral resources. Leasable and salable resources are covered only if they appear in the above documents. Mineral resource assessments are subjective: the opinions expressed herein are entirely those of the author. This report has not been reviewed for stratigraphic nomenclature. Any use of trade, product, or firm names is for descriptive purposes and does not imply endorsement by the U.S. Government. 


\title{
U.S. Department of the Interior
}

\author{
U.S. Geological Survey \\ Box 25046, MS 905 \\ Denver Federal Center \\ Denver CO, 80225
}

October 16, 2007

Mr. Randall Karstaedt

Director, Physical Resources

U.S.D.A. Forest Service

P.O. Box 25127

Lakewood, CO 80225-0127

Dear Mr. Karstaedt:

This report is in response to your December 27, 2006 (received January 9, 2007) request for information on locatable mineral resources in a land exchange proposal in which Homestake Mining Company of California, Homestake Forest Products Company, and LAC Minerals (USA) LLC have offered certain non-Federal lands within the Black Hills National Forest, in exchange for Federal lands also within the Black Hills National Forest.

In accordance with our long-term working agreement under Public Law 86-509, we are providing you with a report on the locatable mineral resources on the lands described in Exhibits A and B, which were included with your request. These lands comprise approximately 706 acres in Pennington and Lawrence Counties, South Dakota.

Sincerely yours,

Anna B. Wilson, Geologist

Mineral Resources Program, Central Region

$\begin{array}{ll}\text { Copies: } & \text { Connie Nutt } \\ & \text { Ron Baer } \\ & \text { Mike Dunn } \\ & \text { Nancy Hollenkamp } \\ & \text { Craig Kjar }\end{array}$


For the legal location description of lands considered for exchange, refer to Exhibits $\mathrm{A}$ and $\mathrm{B}$ in Attachments A and B. Approximate locations of the parcels are shown on Attachment C. The report request is Attachment $\mathrm{D}$.

\section{Non-Federal}

\section{Rio Tinto (USFS Map 4)}

Piedmont 1:24,000; Rapid City 1:100,000, 1:250,000 quadrangles.

According to the geologic mapping at 1:24,000 (Bayley, 1972), the parcel is primarily in Middle Proterozoic rocks including the Boxelder Creek Quartzite of the Nemo Group, arkose of the Estes conglomerate, black slate and graywacke and siliceous limestone of the Roberts Draw Limestone, and metagabbro dikes and sills. These older rocks are unconformably overlain in the east-central part of the parcel by Cambrian Deadwood Formation (Attachment D), shown in fault contact on the map (Bayley, 1972).

South Dakota Geological Survey's new State geologic map at 1:500,000 scale (General Map G10, Martin and others, 2004, available for download in shape or pdf format from http://www.sddenr.net/publist/search_results_publist.cfm?limit_to_download=Yes\&sql_option=7) shows the parcel straddling three Lower Proterozoic rock units, with the youngest unit in the south and the oldest in the north. The northernmost tip of the claim block is in a $6,000 \mathrm{ft}(1,829 \mathrm{~m})$ thick metaconglomerate unit composed of tan to light-gray, conglomeratic siliceous schist, feldspathic schist, and minor marble. Most of the northern part of the claim block is underlain by $60-300 \mathrm{ft}$ (18-91 m) of metamorphosed dolomite which is a light-gray to light-tan marble, phyllite, and calcareous phyllite. The southern part of the claim block is in metabasalt composed of darkgreen amphibolite, actinolite schist, greenstone, and local iron-formation. Early Proterozoic taconite iron-formation is mapped west of the claim block. A map of the Piedmont quadrangle at $1 ; 24,000$ scale is currently in progress by Jack Redden and the South Dakota Geological Survey (Ed DeWitt, written commun., 7/30/2007).

Rio Tinto claims are on the southeastern edge of the Nemo mineralized area (Wilson and DeWitt, 1995) where there is iron in stratiform metasedimentary deposits that were formed in a submarine environment about 2.2-2.5 billion years ago. The 20-500 ft (6-152 m)-thick ironformation consists of banded, dark-green, reddish-brown, and white iron-formation interbedded with ferruginous chert, and minor mica schist. There may be three or more episodes of oxide-, carbonate-, silicate-, and sulfide-facies iron-formation and interbedded tuffaceous rocks. The metals were concentrated in sedimentary rocks by volcanic or chemical processes (DeWitt and others, 1988d, 87-261-D). There are no mines that have ever been productive closer to the Rio Tinto claims than the Nemo Iron mine (DeWitt and others, 1988d), also known as the old Nemo Ore Company mining cut (Harrer, 1966, p. 37-39), approx. $21 / 2 \mathrm{mi}$. to the north. This mine is labeled "gravel pit" on the geologic map (Bayley, 1972).

Banded iron-formation is not mapped on the parcel (Bayley, 1972). Lacking banded ironformation, mineral resource potential is low. If iron-formation is present on or underlying the parcel, resource potential would be high. No other locatable commodities are known in the vicinity in similar host rocks (Wilson and DeWitt, 1995). 
At 1:500,000 scale, the area is entirely mapped as Lower Permian and Upper Pennsylvanian Minnelusa Formation, a variegated, multicolored unit containing interbedded sandstone, siltstone, shale, limestone, dolomite, calcarenite, chert, and brecciated beds with a total thickness of 394-1,175 ft (120-358 m) (Martin and others, 2004). Geologically, the Billie Spring parcel is almost identical to the Rifle Pit parcel.

Billie Springs is outside the area assessed by DeWitt and others (1986) and is south of the part of Old Baldy Mountain quadrangle included in DeWitt and others (1988, MF-1978-B). No mineral resources are known in the area (http://mrdata.usgs.gov/website/MRDataUS/viewer.htm). Mineral resource potential for all locatable minerals is low. The Bald Mountain gravel pit (presumably this is the Bald Mountain Quarry), 1 1/2 miles to the west, is currently inactive (http://www.fs.fed.us/r2/blackhills/projects/nepa/public_docs/moskee/01_moskee_draftea_0615_ v4.pdf, p. 46, accessed 9/4/2007).

DeWitt (written commun., 8/2007) points out that if lamprophyre dikes cut the Paleozoic rocks in this area (as they do southeast of Tinton), there may be pyroxenite-related copper or carbonatite-related $\mathrm{Cu}-\mathrm{Au}-\mathrm{REE}$ deposits at depth in the area.

\section{$\underline{\text { Rifle Pit (USFS Map 1) }}$}

Buckhorn 1:24,000; Sundance 1:100,000; Gillette 1:250,000 quadrangles.

At 1:500,000 scale, the area is entirely mapped as Lower Permian and Upper Pennsylvanian Minnelusa Formation, a variegated, multicolored unit containing interbedded sandstone, siltstone, shale, limestone, dolomite, calcarenite, chert, and brecciated beds with a total thickness of 394-1,175 ft (120-358 m) (Martin and others, 2004). Geologically, it is almost identical to the Billie Springs parcel.

Rifle Pit is outside the area assessed by DeWitt and others (1986). No mineral resources are known in the area (http://mrdata.usgs.gov/website/MRData-US/viewer.htm). Mineral resource potential for all locatable minerals is low.

If the Minnelusa Formation is thin, it is possible that there could be resource potential for highcalcium limestone in the underlying Pahasapa Limestone (DeWitt, written commun., 8/2007).

\section{Federal}

Grizzly (USFS Map 3)

Deadwoods South 1:24,000; Rapid City 1:100,000; Rapid City 1:250,000 quadrangles.

There are 2 main sub-parcels to the Grizzly parcel: the portion located in the NE corner of sec. 11 and the portion in the southern part of sec. 11 and northern part of sec. 14 (T. 4 N., R. 3 E.). The northern portion abuts or is close to the Norway, Key, Possible, Hard Up, Box, Perhaps, Thanksgiving, and Belgrade (claims 504-511, DeWitt and others, 1988a), to name just a few of the closest. None of these has been productive. The nearest developed prospect, the Woodstock, has an adit located northwest of the center of sec. 11 . There is no record of production. The 
southern sub-parcel is immediately in the vicinity of the Non Such, A.B., Divide Wild Goose, Dabble, Helena, Ordon, Big 4 Fr., Arklas, Niagra, Little Nellie, Big Nellie, and adjacent claims (nos. 525-535, 746, 752, and 755-757, DeWitt and others, 1988a, MF-1978-F).

The entire area is covered with claims and is located at the southern margin of the Two Bit mineralized area (Wilson and DeWitt, 1995). Mineral resource potential for vein and replacement deposits containing gold, silver, and zinc is high.

The LOR and Hoffman iron mines are located east of the parcels. These deposits are included in the Strawberry Ridge metallic mineralized area which contains Cambrian detrital hematite deposits (Wilson and DeWitt, 1995, p. 64; DeWitt and others, 1986, p. 95) and has moderate potential for iron in a medium to small deposit.

Richmond Hill (USFS Map 2)

Spearfish 1:24,000; Rapid City 1:100,000; Rapid City 1:250,000 quadrangles.

The geology of the Richmond Hill area is complex. No mapping at large scale is currently available. This assessment is based on the 1:500,000-scale State geologic map (Martin and others, 2004), which shows that the Richmond Hill tracts are underlain by Eocene and Paleocene trachytic and rhyolitic intrusive rocks, Lower Mississippian to Cambrian sedimentary rocks, and Lower Proterozoic metaquartzite and metasiltstone.

Each of the parcels is surrounded by patented claims (DeWitt and others, 1988b). Almost all of the tracts are within the Richmond Hill mineralized area (Wilson and DeWitt, 1995). This area has high potential for Cenozoic porphyry gold systems (DeWitt and others, 1986). The northern part of the parcel overlaps the Carbonate mineralized area, an area that has high potential for Cenozoic replacement deposits of lead, silver, and zinc (Wilson and DeWitt, 1995; DeWitt and others, 1986). Maps and figures by DeWitt and others (1986) suggest the Richmond Hill parcel may have moderate potential for medium-sized, syngenetic stratiform gold deposits with byproduct silver and arsenic, moderate potential for medium-small, disseminated molybdenum, silver, and lead deposits, and high potential for medium-sized, disseminated or porphyry gold, silver, and copper deposits. Overall, this parcel has high mineral resource potential.

\section{LIST OF ATTACHMENTS}

A. Exhibit A. Legal description of the Non-Federal parcels (Rio Tinto, Billie Springs, and Rifle Pit) considered in this land exchange (provided by USDA Forest Service).

B. Exhibit B. Legal description of the Federal parcels (Grizzly and Richmond Hill) considered in this land exchange (provided by USDA Forest Service).

C. Report Request (provided by USDA Forest Service).

D. Geology in the vicinity of the Rio Tinto parcel (from Bayley, 1972). 


\section{REFERENCES:}

Bayley, R.A., 1972, Preliminary geologic map of the Nemo district, Black Hills, South Dakota: U.S. Geological Survey Miscellaneous Geologic Investigations map I-712, scale $1: 24,000$.

DeWitt, Ed; Redden, J.A.; Wilson, Anna Burack; and Buscher, David, 1986, Mineral resource potential and geology of the Black Hills National Forest, South Dakota and Wyoming, with a section on Salable commodities, by J.S. Dersch: U.S. Geological Survey Bulletin 1580, $135 \mathrm{p}$.

DeWitt, Ed; Buscher, David; Wilson, Anna Burack; and Johnson, Tom, 1988a, Map showing locations of mines, prospects, and patented mining claims, and classification of mineral deposits in the Deadwood South 7 1/2-minute quadrangle and part of the Deadman Mountain 7 1/2-minute quadrangle, Black Hills, South Dakota: U.S. Geological Survey Miscellaneous Field Studies Map MF-1978-F, scale 1:24,000.

DeWitt, Ed; Buscher, David; Wilson, Anna Burack; and Johnson, Tom, 1988b, Map showing locations of mines, prospects, and patented mining claims, and classification of mineral deposits in the Spearfish 7 1/2-minute quadrangle, Black Hills, South Dakota: U.S. Geological Survey Miscellaneous Field Studies Map MF-1978-C, scale 1:24,000.

DeWitt, Ed; Buscher, David; Wilson, Anna Burack; and Johnson, Tom, 1988c Map showing locations of mines, prospects, and patented mining claims, and classification of mineral deposits in parts of the Tinton and Old Baldy Mountain 7 1/2-minute quadrangles, Black Hills, South Dakota and Wyoming: U.S. Geological Survey Miscellaneous Field Studies Map MF-1978-B, scale 1:24,000.

DeWitt, Ed; Buscher, David; Wilson, Anna Burack; and Johnson, Tom, 1988d, Map of mines, prospects, and patented mining claims, and classification of mineral deposits in the Nemo 7 1/2-minute quadrangle, and the western one-third of the Piedmont 7 1/2-minute quadrangle, Black Hills, South Dakota: U.S. Geological Survey Open-File Report OF 87-261-D, scale 1:24,000.

Harrer, C.M., 1966, Iron resources of South Dakota: U.S. Bureau of Mines Information Circular 8278, p. 37-39.

Martin, J.E., Sawyer, J.F., Fahrenbach, M.D., Tomhave, D.W., and Schulz, L.D., 2004, Geologic map of South Dakota: South Dakota Geological Survey, General Map 10, scale $1: 500,000$.

(http://www.sddenr.net/publist/search_results_publist.cfm?limit_to_download=Yes\&sql_option=7)

Wilson, Anna B., and DeWitt, Ed, 1995, Map showing metallic mineral districts and mines in the Black Hills, South Dakota and Wyoming: U.S. Geological Survey Miscellaneous Investigations Series Map I-2445, scale 1:100,000. Includes 72 p. pamphlet. 
Attachment A. Exhibit A. Legal description of the Non-Federal parcels (Rio Tinto, Billie Springs, and Rifle Pit) considered in this land exchange (provided by USDA Forest Service).

\section{EXHIBIT A}

Property that the Non-Federal Party will consider exchanging:

Black Hills Meridian, Pennington County, South Dakota

\section{$\underline{\text { Rio Tinto }}$}

Rio Tinto Lode, Rio Tinto No. 1, Rio Tinto No. 2, Rio Tinto No. 3, Rio Tinto No. 4, and Rio Tinto Fraction, Mineral Survey 1592, located in sections 11 and 14, T. 2 N., R. 5 E.

Containing 58.73 acres, more or less.

\section{Black Hills Meridian, Lawrence County, South Dakota}

\section{Billie Springs}

Homestead Entry Survey (HES) No. 611 located in section 6, T. 3 N., R. 1 E., and section 31 , T. 4 N., R. 1 E.

Containing 113.59 acres, more or less.

\section{$\underline{\text { Rifle Pit }}$}

Tracts B \& C of Homestead Entry Survey (HES) 615 lying in section 8, located in section 8 , T. 3 N., R. 1 E.

Containing 54.81 acres, more or less.

Containing an aggregate of $\underline{\mathbf{2 2 7 . 1 3 1}}$ acres, more or less. 
Attachment B. Exhibit B. Legal description of the Federal parcels (Grizzly and Richmond Hill) considered in this land exchange (provided by USDA Forest Service).

\section{EXHIBIT B}

Property that the U.S.D.A. Forest Service will consider exchanging:

\section{Black Hills Meridian, Lawernce County, South Dakota}

\section{$\underline{\text { Grizzly }}$}

T. 4 N., R. 3 E.

sec. 11, portion of lot 1 , lots $2-6$, portion of lot 7 , lots $8-10$, portion of lot 11 , lot 12 ; sec. 12, lot 13;

sec. 13, portion of lot 3 ; and

sec. 14 , portion of lot 1 , and lots $2-3$.

Containing 133.98 acres, more or less.

\section{Richmond Hill}

T. 5 N., R. 2 E.

sec. 11, portion of lot 7;

sec. 13 , lot 12 ;

sec. 14, lots $2-4$ and lots 7-10;

sec. 23 , lots 1-8; and

sec. 24, lot 3 and portion of lot 4 .

Containing 344.88 acres, more or less.

Containing an aggregate of $\underline{478.86}$ acres, more or less. 
Attachment C. Approximate location of the parcels shown on the Black Hills National Forest Map.

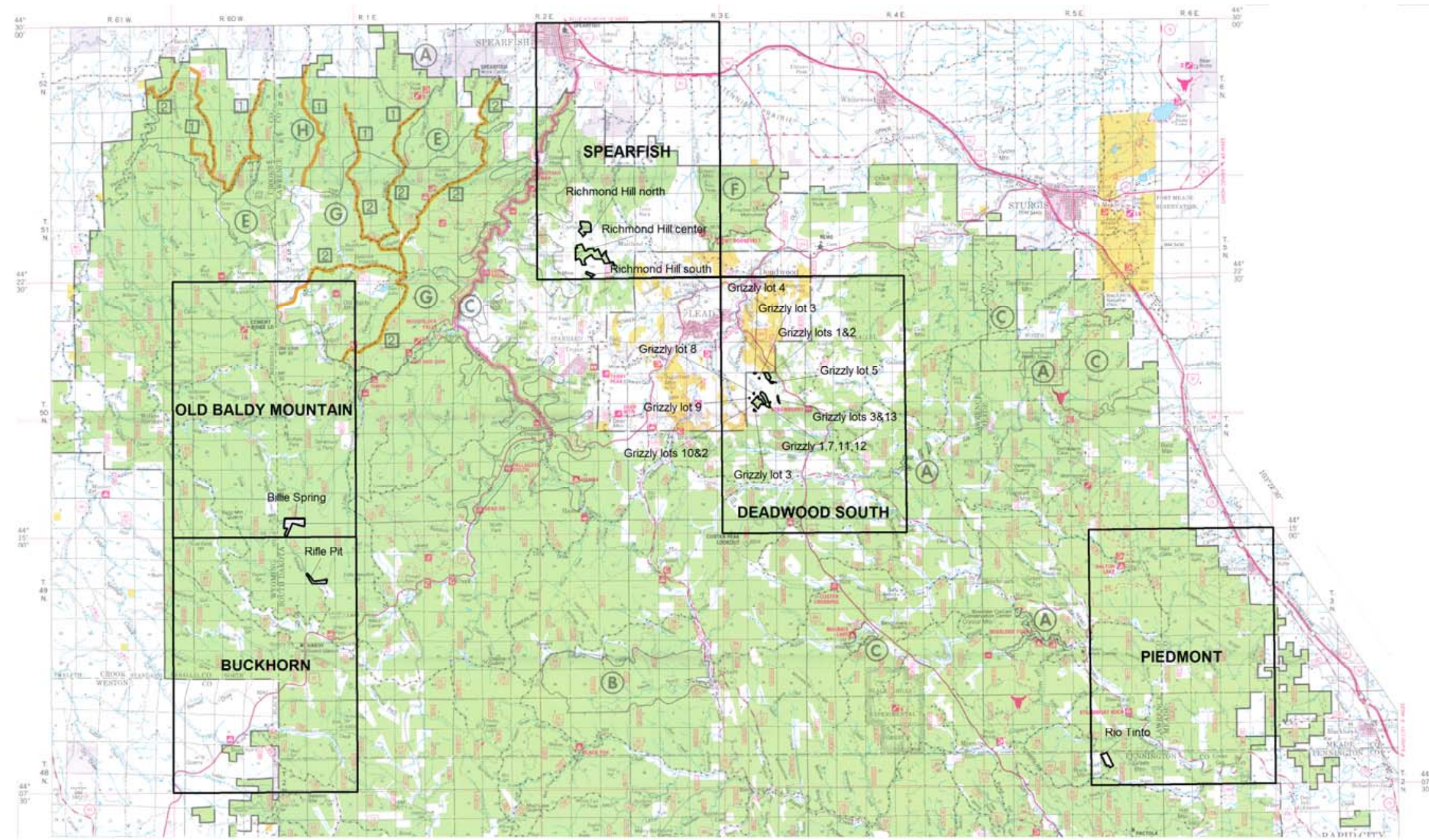


Attachment D. Report Request (provided by USDA Forest Service).

\begin{tabular}{llll} 
USDA United States & Forest & Rocky & P.o. Box 25127 \\
Department of & Service & Mountain & Lakewood, CO 80225-0127 \\
Agriculture & & Region & Delivery: 740 Simms Street \\
& & Golden, CO 80401 \\
& & Voice: 303-275-5350 \\
& & TDD: 303-275-5367 \\
\hline
\end{tabular}

File Code: $5430-2-1$

Date:

Anna Wilson

DEC 272006

Geologist

U.S. Geological Survey

Central Mineral Resources MS 905

Box 25046, Denver Federal Center

Denver, CO 80225

Dear Ms. Wilson:

Homestake Mining Company of California, Homestake Forest Products Company, and LAC Minerals (USA) LLC, has offered certain non-Federal lands within the Black Hills National Forest, in exchange for Federal lands also within the Black Hills National Forest. These lands are generally described in Exhibits A and B enclosed herewith. The lands to be exchanged are depicted on the maps also provided.

In accordance with the working agreement under Public Law 86-509, please provide a report on the locatable mineral resources on the lands described in Exhibits A and B. Please specify in your report the mineral or minerals involved. Please send your report to the letterhead address.

If you have any questions, you may contact Nancy Hollenkamp at (303) 275-5382.

Sincerely,

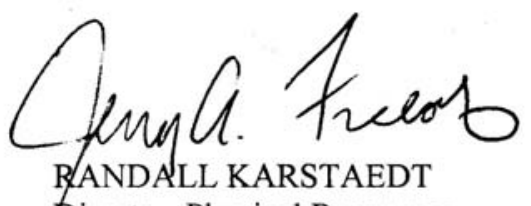

$\int d r$

Director, Physical Resources

Enclosures

cc: Craig Kjar 
Attachment D. Geology in the vicinity of the Rio Tinto parcel (from Bayley, 1972). Rock units exposed in the parcel, from oldest to youngest, are: Boxelder Creek Quartzite (bc, tan); arkose of the Estes Conglomerate (ea, orange); siliceous limestone of the Roberts Draw Limestone (rdls, gray-blue), black and gray slate (rdsl); metagabbro dikes and sills (mg, olive green); and sedimentary rocks of the Deadwood Formation (Pzs, brown). Approximate scale is smaller than $1: 24,000$.

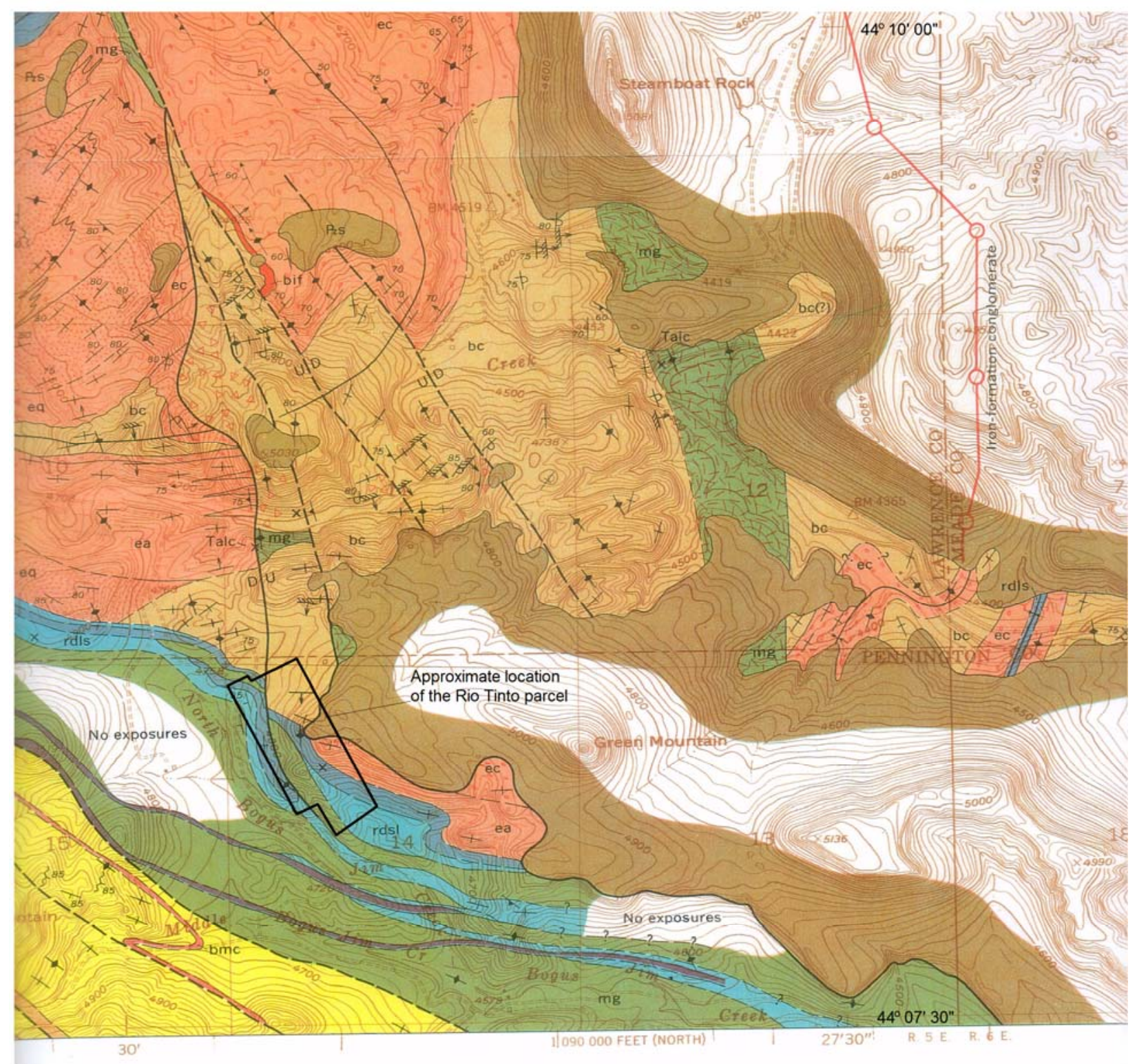




\section{WYOMING}




\section{LOCATABLE MINERAL REPORT FOR THE \\ MOSKEE AND WATSON LAND EXCHANGE OFFER, BLACK HILLS NATIONAL FOREST, CROOK COUNTY, WYOMING}

By

Anna B. Wilson

U.S. Geological Survey

Administrative Report

June 25, 2009

The following report is based on information contained in USGS mineral resource and commodity files, in mineral information databases (MRDS and MAS), and on reports and maps available in the USGS library. These data are occasionally augmented with unpublished documents, personal communications, and professional experiences. No field studies or on-site visits were performed in preparing this report. Emphasis is primarily on locatable mineral resources. Leasable and salable resources are covered only if they appear in the above documents. Mineral resource assessments are subjective: the opinions expressed herein are entirely those of the author. This report has not been reviewed for stratigraphic nomenclature. Any use of trade, product, or firm names is for descriptive purposes and does not imply endorsement by the U.S. Government. 


\title{
U.S. Department of the Interior
}

\author{
U.S. Geological Survey \\ Box 25046, MS 905 \\ Denver Federal Center \\ Denver CO, 80225
}

May 26, 2009

Mr. Randall Karstaedt

Director, Physical Resources

U.S.D.A. Forest Service

P.O. Box 25127

Lakewood, CO 80225-0127

Dear Mr. Karstaedt:

This report is in response to your April 7, 2009 request for information on locatable mineral resources in a land exchange proposal in which Moskee Land Corporation, Inc., and Watson Land, LLC, have offered certain non-Federal lands within the Black Hills National Forest, in exchange for Federal lands also within the Black Hills National Forest. These lands comprise approximately 1,677 acres in Crook County, Wyoming.

In accordance with our long-term working agreement under Public Law 86-509, we are providing you with a report on the locatable mineral resources on the lands described in Exhibits $\mathrm{A}$ and $\mathrm{B}$, which were included with your request.

Sincerely yours,

Anna B. Wilson, Geologist

Mineral Resources Program, Central Region

Copies: Connie Nutt

Nancy Hollenkamp 
For the legal location description of lands considered for exchange, refer to Exhibits A and B in Attachments A and B. Approximate locations of the parcels and the geology are shown on Attachment C. Mineral resource assessment tracts are shown on Attachment D. The report request is Attachment $\mathrm{E}$, location map is Attachment F.

This report deviates in format from that of previous reports in that, to avoid repetition, the geology is discussed for all parcels first, followed by the resource potential. (Previous reports discuss the geology and resource potential of each non-federal parcel, then for each federal parcel.) A "NF-" prefix signifies National Forest lands.

\section{$\underline{\text { Geology }}$}

All of the parcels in this exchange are in the Devonian to Permian (possibly as young as Triassic) sedimentary sequence (Attachment C; after DeWitt and others, 1989) flanking the Precambriancored Black Hills. From oldest to youngest the sequence includes the Upper Devonian to Lower Mississippian Englewood Formation to Lower Mississippian Pahasapa Limestone (combined as unit MDpe: dark gray). This is overlain by Pensylvanian to Lower Permian Minnelusa Formation (unit PIPm, medium blue), then by lower Permian Opeche Shale and Minnekahta Limestone (combined as unit Pmo; pale blue), and finally by Permian and Triassic Spearfish Formation (TrPs; light green). Eocene and Paleocene trachytic rocks (unit Tt; dull orange) intrude the sequence at Black Buttes.

Note that the scale of mapping is 1:250,000, and thus inexact. Parcels close to the boundaries may be in either of the adjacent formations. Prior mapping of this area was in 1905 at 1:125,000-scale (Darton, 1905). A 2007 digital map of the Sundance 30 X 60 quadrangle at 1:100,000-scale, released by the Wyoming State Geological Survey (Sutherland, 2007), was not obtained in time for this report.

Only the non-federal Watson parcel is within the oldest unit (MDpe). Most of the parcels under consideration for this exchange are primarily in the Minnelusa Formation (PIPm): NF-B and C; Moskee B-H; NF-Moskee A, B, E, G; and NF-Watson. Three parcels are mapped near the contact of both the PIPm and Pmo: NF-A, NF-Moskee C, D. NF-Moskee H and I are almost entirely within the younger Pmo unit. NF-Moskee F is within both Pmo and TrPs. Moskee A may be influenced by the trachyte intrusion at the margin of PIPm and Pmo.

\section{$\underline{\text { Resource Assessment Tracts }}$}

DeWitt and others assessed the mineral resources of the Black Hills National Forest and vicinity (DeWitt and others, 1986).

Most of the parcels are outside any mineralized areas (Wilson and others, 1995) but there are areas of mineral resource potential (Attachment D, after DeWitt and others, 1986). Parcels with negligible resource potential include: NF-B and C, NF-Watson, NF-Moskee A and B, Moskee B, and $\mathrm{D}-\mathrm{H}$.

Two parcels, Watson and Moskee C, fall within the M1 area (DeWitt and others, 1986, plate 2 and fig. 20, p. 74-75) with moderate potential for medium-sized, high-calcium limestone ("bedded sedimentary deposits formed in shallow-water marine environment about 250-350 Ma by precipitation of calcium carbonate from seawater and accumulation of organisms rich in 
calcium carbonate"(DeWitt and others, 1986, pl. 2)). However, the tracts are so small, and the resource so widespread elsewhere at much higher potential, that the chance of these tracts being a source of this commodity is negligible.

Nine of the parcels, NF-Moskee C - I, Moskee A, and NF-A, are in the M2 resource area. This area has high potential for large-sized, high-calcium deposits. However, there are no known mines or known deposits in the area, and the probability of developing any such deposits here is minimal. Although geology permissive for the occurrence of such deposits is present, there is no sign that there has been exploration or development for any in this area.

Two parcels, Moskee $\mathrm{C}$ and $\mathrm{D}$, are in an area of unknown resource potential for disseminated and carbonatite deposits (WXY1). Where such deposits occur, they may be "fracture-filling, vein, or disseminated concentration[s] of base and precious metals and rare-earth-element-rich metals formed in plutonic to subvolcanic environment[s] about 50-60 Ma by fracturing and metasomatic alteration of Tertiary alkaline igneous complexes and associated carbonatite" (DeWitt and others, 1986, pl. 2). Expected commodities might be REE, Th, U, Au, and Ag.

\section{LIST OF ATTACHMENTS}

A. Exhibit A. Legal description of the Non-Federal parcels (Moskee A-H and Watson) considered in this land exchange (provided by USDA Forest Service).

B. Exhibit B. Legal description of the Federal parcels (NF A-C, NF-Watson, NF-Moskee A-I) considered in this land exchange (provided by USDA Forest Service).

C. Geology and approximate location of land exchange parcels (from DeWitt and others, 1989)

D. Mineral resource assessment tracts and approximate location of land exchange parcels (from DeWitt and others, 1986).

E. Report Request (provided by USDA Forest Service).

F. Land exchange location map (provided by USDA Forest Service). 


\section{$\underline{\text { REFERENCES: }}$}

DeWitt, Ed; Redden, J.A.; Wilson, Anna Burack; and Buscher, David, 1986, Mineral resource potential and geology of the Black Hills National Forest, South Dakota and Wyoming, with a section on Salable commodities, by J.S. Dersch: U.S. Geological Survey Bulletin $1580,135 \mathrm{p}$.

DeWitt, Ed; Redden, J.A.; Buscher, David; and Wilson, Anna Burack, 1989, Geologic map of the Black Hills area, South Dakota and Wyoming: U.S. Geological Survey Miscellaneous Investigations Series Map I-1910, scale 1:250,000.

Sutherland, W.M., 2007, Geologic map of the Sundance 30' x 60' Quadrangle, Crook and Weston Counties, Wyoming and Lawrence and Pennington Counties, South Dakota: Wyoming State Geological Survey Map Series MS-78, scale 1:100,000.

Wilson, Anna B., and DeWitt, Ed, 1995, Map showing metallic mineral districts and mines in the Black Hills, South Dakota and Wyoming: U.S. Geological Survey Miscellaneous Investigations Series Map I-2445, scale 1:100,000. Includes 72 p. pamphlet. 
Attachment A. Exhibit A. Legal description of the Non-Federal considered in this land exchange (provided by USDA Forest Service).

\section{EXHIBIT A}

Property that the Non-Federal Party will consider exchanging:

\section{Sixth Principal Meridian. Crook County, Wyoming}

T. $49 \mathrm{~N}, \mathrm{R} 60 \mathrm{~W}$.

Tract 37, formerly sec. 4, lots 1 and 4;

H.E. Survey No. 78, comprising Tract A and B embracing a portion of sections 17 \& 18;

H.E. Survey No. 141;

H.E. Survey No. 144, comprising Tracts A, B and C embracing a portion of sections

$7,8, \& 18$; and

T. 50 N., R. $60 \mathrm{~W}$.

Tract 38;

H.E. Survey No. 88, comprising Tracts A and B embracing portion of sections 28 \& 33;

H.E. Survey No. 146;

A portion of H.E. Survey 143, lying north of the centerline of FR 804.1; and

T. 50 N.. R. 61 W.

sec. $22 \mathrm{SW} 1 / 4 \mathrm{SW}^{1 / 4}$; and

T. 50 N., R. 62 W.

$\sec .25 \mathrm{NE}^{1 / 4} \mathrm{SW}^{1 / 4}, \mathrm{SE}^{1 / 4 \mathrm{NW}^{1} / 4}$.

Containing 733.23 acres, more or less.

Land reservations of the Non-Federal Party and exceptions to title:

Reservations: None

Outstanding Rights

1. Reservations as contained in Warranty Deed recorded May 7, 1914 in Book 32 of Deeds at page 168.

2. Right of way easement and right-of-way to construct and maintain a road, including terms and conditions contained therein, granted to The County of Crook, State of Wyoming, recorded July 14, 1956 in Book 28 of Photos 465; Quitclaim Deed and Notice of Abandonment recorded February 6, 1992 in Book 308 of Photos at page 72; and Resolution \#1992-3 and Abandonment of Easement recorded February 6, 1992 in Book 308 of Photos at page 74. (NOTE: If Crook County had quitclaimed and abandoned this easement; it should not be included in the final policy for this transaction.)

3. Right of way for highway purposes, granted to the United States of America, recorded September 3, 1965 in Book 84 of Photos at page 525.

4. Right of way for highway purposes, including terms and conditions contained therein, granted to the United States of America, recorded September 3, 1965 in Book 96 of Photos at page 186. 
5. Short Form Grant of Rights from Homestake Forest Products Company, a California corporation, Short Form Grant of Rights from Homestake Forest Products Company, a California corporation, unto Pope \& Talbot, Inc., a Delaware corporation, recorded February 11, 1981 in Book 182 of Photos, page 118. Amendment to Timber Cutting and Timberlands Management Agreement recorded January 17, 2002 in Book 390 of Photos, page 596.

Confirmation of Withdrawal and Surrender of Lands from Timber Cutting and Timberlands Management Agreement recorded March 16, 2001 in Book 381 of Photos, page 649.

Withdrawal of Lands from Timber Cutting and Timberlands Management agreement recorded March 1, 1996 in Book 341 of Photos, page 749. Memorandum of Amendment recorded August 22, 1996 in Book 345 of Photos, page 418. Withdrawal and Surrender of Lands from Timber Cutting and Timberlands Management Agreement recorded March 16, 2001 in Book 381 of Photos, page 653. Surrender of Rights recorded August 9, 2002 in Book 397 of Photos, page 97. Withdrawal and Surrender of Lands form Timber Cutting and Timberlands Management Agreement recorded December 17, 2002 in Book 401 of Photos, page 358.

6. Right of way for road purposes, granted to the United States of America, recorded April 10, 1987 in Book 260 of Photos at page 32.

7. Right of way for road purposes, including terms and conditions contained therein, granted to the United States of America, recorded September 10, 1991 in Book 305 of Photos at page 231.

8. Right of way for road purposes, including terms and conditions contained therein, granted to the United States of America, recorded September 10, 1991 in Book 305 of Photos at page 234.

9. Right of way for road purposes, including terms and conditions contained therein, granted to the United States of America, recorded March 17, 1992 in Book 309 of Photos at Page 6; and Correction Deed recorded October 3, 2002 in Book 399 of Photos at page 131.

10. Right of way for the reconstruction, maintenance, and full, free and quiet use and enjoyment of the existing roads, including terms and conditions contained therein, granted to the United States of America, recorded August 11, 1992 in Book 312 of Photos at page 609. 
Attachment B. Exhibit B. Legal description of the Federal parcels (Grizzly and Richmond Hill) considered in this land exchange (provided by USDA Forest Service).

\section{EXHIBIT B}

Property that the U.S.D.A. Forest Service will consider exchanging:

\section{Sixth Principal Meridian, Crook County, Wyoming}

T. 50 N., R. $61 \mathrm{~W}$. sec. 24, NW1/4NW1/4SW1/4, W1/2W1/2SW1/4NW1/4, W1/2E1/2W1/2SW1/4NW1/4; sec. 27, N1/2NE1/4, SE1/4NE1/4, NE1/4SE1/4, S1/2SE1/4, SE1/4SW1/4, NE1/4NW1/4; sec. 28, NE1/4NW1/4; sec. $29, \mathrm{~S} 1 / 2 \mathrm{~N} 1 / 2$; sec. 30 , lot 4 , NW1/4SE1/4, SE1/4NW1/4; and sec. 3̧, E1/2NE1/4, SE1/4SW1/4, SE1/4NW1/4.

Containing 823.42 acres, more or less.

Additional Federal land to be included, if necessary, to equalize values:

T. 50 N., R. 61 W. sec. 9, SW1/4SW1/4; sec. 15 , SW1/4SWl/4.

T. 51 N., R. 61 W. sec. $28, \mathrm{NW} 1 / 4 \mathrm{NW} 1 / 4$.

Containing 120.00 acres, more or less.

Land reservations of the U.S.D.A. Forest Service, exceptions to title and uses to be recognized:

Reservations:

1. Reserving to the United States a right-of-way thereon for ditches or canals constructed by the authority of the United States Act of August 30, 1890 (26 Stat: 391; 43 U.S.C. 845).

Outstanding Rights: None

Other:

1. Special Use Permit issued to Range Telephone Coop, Inc. for an existing phone line may affect one or more parcels. Site inspections will be necessary to verify. The Forest will obtain a waiver/relinquishment/amendment for any portion of the permit affected by the exchange at or prior to closing. The non-Federal party will be required to issue an easement replacing this permit at closing.

2. Special Use Permit issued to Powder River Energy Corporation for an existing powerline may affect one or more parcels. Site inspections will be necessary to verify. The Forest will obtain 
a waiver/relinquishment/amendment for any portion of the permit affected by the exchange at or prior to closing. The non-Federal party will be required to issue an easement replacing this permit at closing.

3. Special Use Permit issued to Sully Simons for outfitting/guiding. The Forest will obtain a waiver/relinquishment/amendment for any portion of the permit affected by the exchange at or prior to closing.

4. Grazing Allotment Permit for the Silver Creek Allotment issued to one of the non-Federal parties shall be modified at closing.

5. Grazing Allotment Permit for the Willow Springs Allotment is issued to a permittee not involved in the exchange. The permittee should be requested to voluntarily relinquish the permit at closing. If the permittee is unwilling, they should be provided with the two year notification in 36 CFR 222.4. In the case of the latter, the patent would be issued subject to the remainder of the 2 year period from when the permittee was provided the 2 -year notification. 
Attachment C. Geology and approximate location of land exchange parcels (from DeWitt and others, 1989).

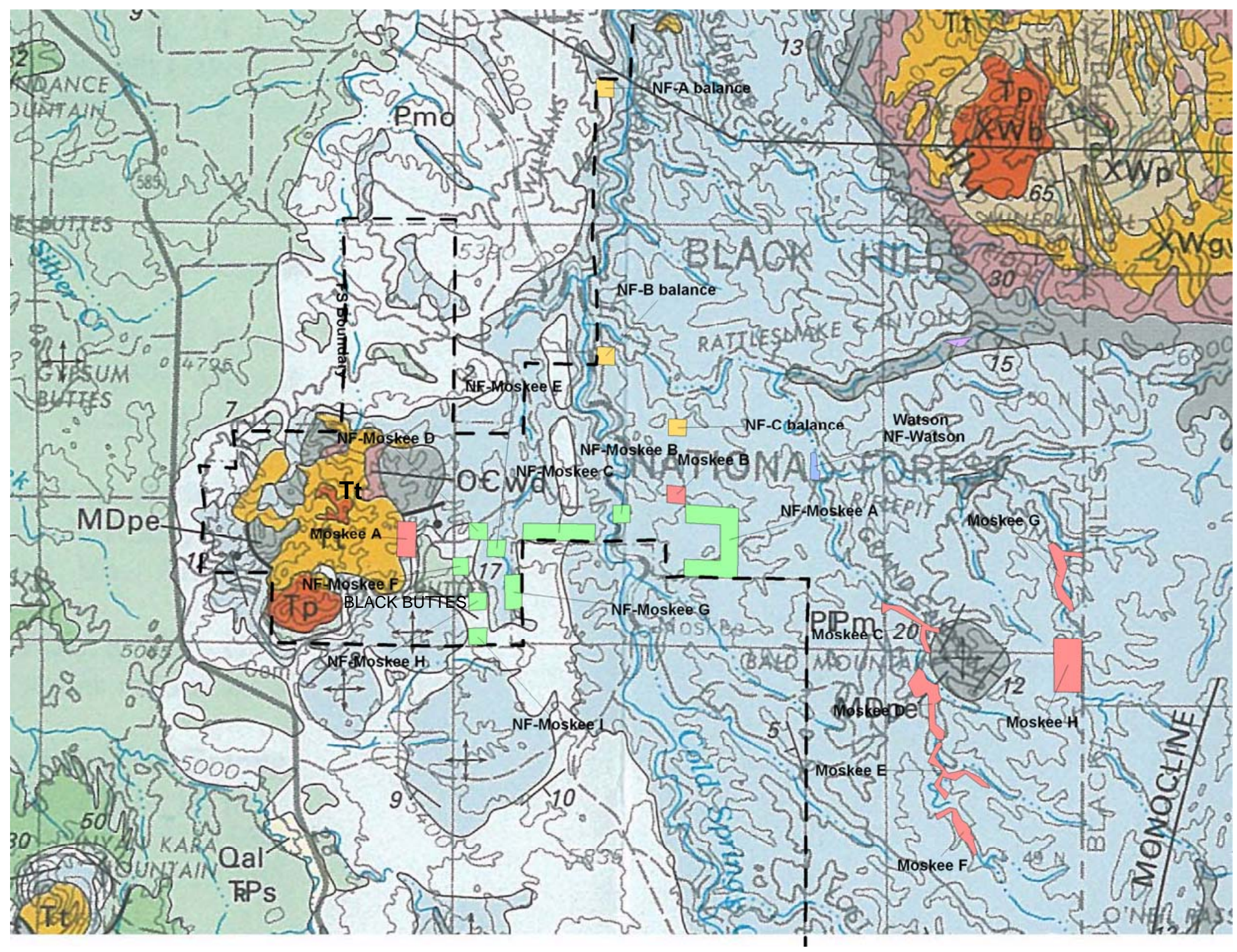

Upper Devonian to Lower Mississippian Englewood Formation to Lower Mississippian Pahasapa Limestone (combined as unit MDpe: dark gray). Pensylvanian to Lower Permian Minnelusa Formation (unit PIPm, medium blue). Lower Permian Opeche Shale and Minnekahta Limestone (combined as unit Pmo; pale blue). Permian and Triassic Spearfish Formation (TrPs; light green). Eocene and Paleocene trachytic rocks (unit Tt; dull orange) intrude the sequence at Black Buttes. 
Attachment D. Mineral resource assessment tracts and approximate location of land exchange parcels (from DeWitt and others, 1986).

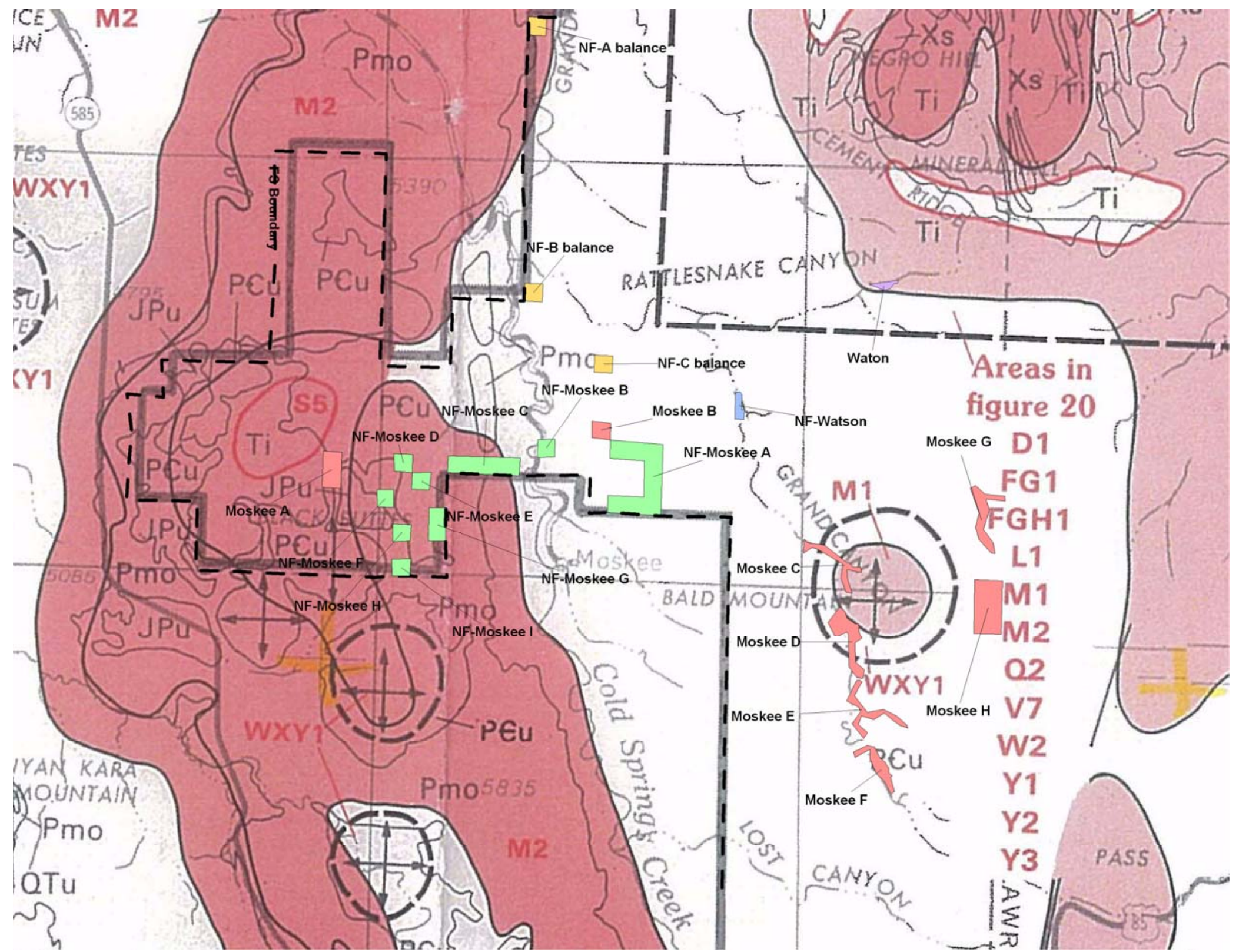


Attachment E. Report Request (provided by USDA Forest Service).

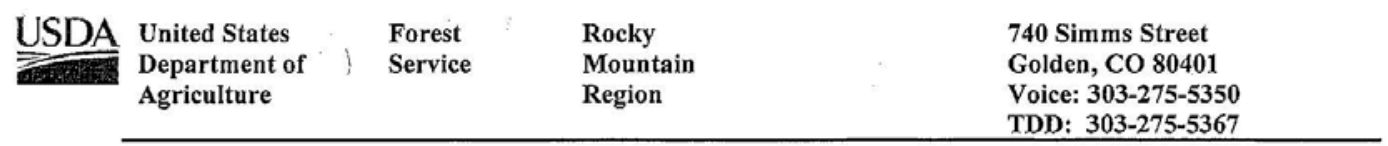

Anna Wilson

$\begin{array}{lr}\text { File Code: } & 5430-2-1 \\ \text { Date: } & \text { APR } 072009\end{array}$

Geologist

U.S. Geological Survey MS 905

Central Mineral Resources

Box 25046, Denver Federal Center

Denver, CO 80225

Dear Ms. Wilson:

Moskee Land Corporation, Inc., of 745 Ferndale Road North, Wayzeta, MN 55391 and Watson Land, LLC, of P.O. Box 21, 171 Moskee Road, Sundance, WY 82729 have offered certain nonFederal lands within the Black Hills National Forest, in exchange for Federal lands also within the Black Hills National Forest. These lands are generally described in Exhibits A and B enclosed herewith. The lands to be exchanged are depicted on the map also provided.

In accordance with the working agreement under Public Law 86-509, please provide a report on the locatable mineral resources on the lands described in Exhibits A and B. Please specify in your report the mineral or minerals involved. Please send your report to the letterhead address.

If you have any questions, you may contact Nancy Hollenkamp at (303) 275-5382.

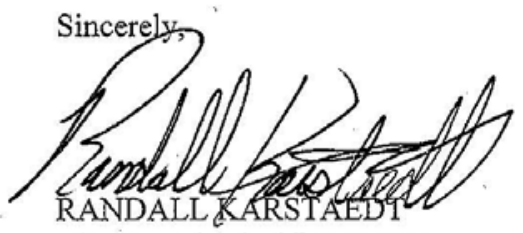

Director, Physical Resources

Enclosures

cc: Jeanette M Timm, Steve Kozel, Michael W Beale 
Attachment F. Land exchange location map (provided by USDA Forest Service).

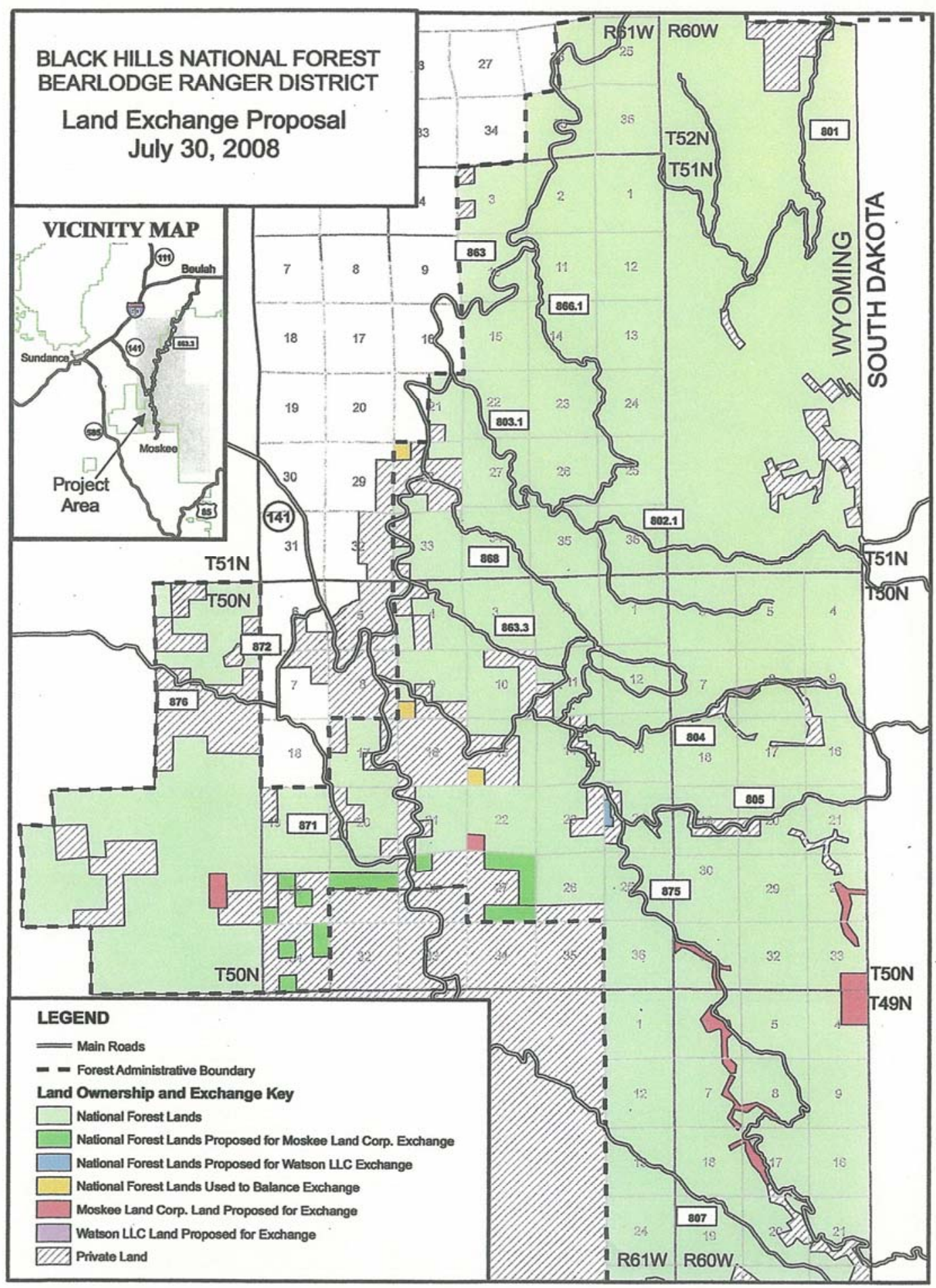

